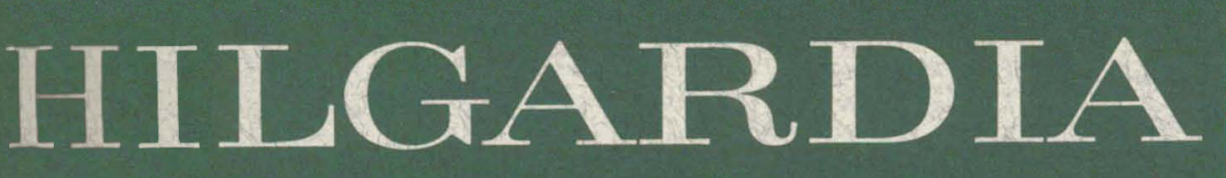

A JOURNALOF AGRICULTURAL SCIENCE PUBLISHED BY THE CALIFORNIAAGRICULTURALEXPERIMENT STATION

Volume 37, Number $15 \cdot$ November, 1966

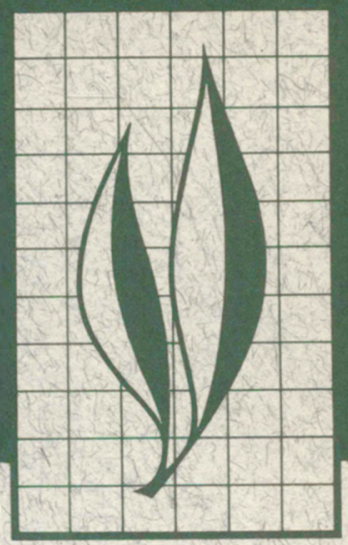

Notes on California Aphids, with Descriptions of New Genera and New Species (Homoptera: Aphididae)

D. Hille Ris Lambers 


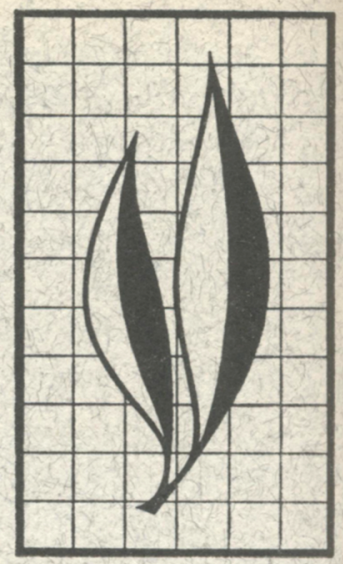

The author, who is one of the world's most distinguished authorities on aphids, presents the results of extensive collecting activity while sojourning in California during the winter of 1963-1964 and the following spring. The research recorded in the present paper is destined to be of great value to entomologists everywhere. Complete descriptions are given of many aphid species not previously known to occur in California, together with a number of keys. In addition, several other species in this category are noted, and certain earlier misidentifications are corrected. (See pages 622 and 623 for a classified, alphabetical index to the many genera and species treated.) Mr. Hille Ris Lambers' collecting trips took him through the University of California campus and other parts of Berkeley; into the San Francisco sand dunes; and to various areas in the counties of Contra Costa, Marin, Monterey, Napa, Riverside, San Diego, Santa Clara, and Santa Cruz. He was accompanied and guided on these excursions by faculty members from three campuses of the University, who were of much assistance in their respective territories; in some cases, submitting valuable mounted material for study.

\section{THE AUTHOR:}

Dirk Hille Ris Lambers is the head of Bladluisonderzoek T.N.O. (Aphid Research Unit of the Netherlands Agricultural Research Council) at Bennekom, Netherlands. This type of investigation has constituted his life's work, with emphasis at present on virus transmission by aphids. He has made many other valuable contributions to entomological literature. 


\title{
Notes on California Aphids, with Descriptions of New Genera and New Species
}

\author{
(Homoptera: Aphididae) ${ }^{1}$
}

\section{INTRODUCTION}

IN SPARE MOMENTS during a stay of six months in California, an attempt was made to obtain a picture of the regional aphid fauna. Although W. M. Davidson, E. O. Essig, A. F. Swain, W. W. Sampson, and others had published studies of California aphids, a considerable number of species not known to occur in North America were found. This is most probably because a different technique for collecting was used.

In the following pages, those species new to California are described or recorded, and some misidentifications are corrected.

The classification applied in the present paper is closely related to that proposed by Börner (1930), ${ }^{2}$ and subsequently modified by Börner and several other European aphid workers. This approach requires the study of a number of characters of larvae and adults that are virtually invisible unless the specimens are cleared before mounting -a technique considerably less cumbersome than mounting in balsam. Consequently, the "European" classification gained no foothold in North America until about 1950, when first E. O. Essig, and then others, began making mounts of cleared specimens.

Some terms are used that are not in common use in North America, e.g.: Exules $=$ in species with host alternation, the apterous and alate viviparae, born on secondary hosts ("exiles"); gynoparae = alate viviparae that produce only oviparae; processus terminalis = the attenuated part, or "unguis," of the last antennal segment; rhinaria = sensoria found on the flagellum of the antennae of alate aphids and often also in apterous morphs; siphunculi = cornicles; stigmal pori $=$ spiracles.

\section{ADDITIONS TO THE CALIFORNIA APHID FAUNA}

Holotypes and paratypes of species described by the author are deposited in his collection. He will send them on loan to anyone working in this field of study. Paratypes of these species will be de- posited in the collection of the California Insect Survey of the Department of Entomology and Parasitology, University of California, Berkeley, following the publication of this paper.

\footnotetext{
${ }^{1}$ Submitted for publication October 12, 1965.

"See "Literature Cited" for citations, referred to in the text by author and date.
} 


\section{Amphorophora stachyophila n. sp.}

\section{Apterous viviparous female}

In life. Light green, without a median brighter stripe, rarely greenish pink, rather shiny, without a trace of waxy exudation. Siphunculi pale, sometimes with smoky tip; cauda light green. Legs pale, with blackish tips to the tibiae and blackish tarsi.

In mounted specimens. Body about 2.5-3.5 mm long, rather elongate, with membranous tergum. Dorsal hairs stiff, rather thick, bluntish or with faintly incrassate apices, about 10 on each of segments II-IV, where the longest is about $1.33^{3}$ times basal diameter of antennal segment III; tergite VIII with 6-8 hairs. Marginal tubercles on abdominal segments II-IV rather commonly present between the two marginal hairs, flat and small. Frontal tubercles well developed, diverging; frontal furrow but little narrower than width of frontal tubercles, its bottom flat; frontal tubercles with two hairs on inner side, one ventrally. Antennae 1-1.2 times as long as body, pale, with the very apices of segments III and IV, distal part of $\mathrm{V}$, and all of VI darkish smoky brown; segment III with some (12-24) rather flat rhinaria more or less in a row, with occasionally one alongside, over basal .50-.80 part; IV without rhinaria; interrelation of segments, see measurements; longest hair on segment III .57-.71 of basal diameter of the segment. Rostrum reaching to just past hind coxae, very hairy; last segment 1.5 times as long as second joint of hind tarsi, with 26-30 hairs besides the 3 subapical pairs. Legs long, smooth, with the exception of some faint spinulose imbrications on caudal side of apical part of femora; tibiae with the spiny, sloping, dorsal hairs just shorter than diameter of mid-portion of hind tibiae; first tarsal joints with $3,3,3$ hairs; second joints imbricated without spinules, with 4-5 ventral pairs of hairs; empodial hairs about two-thirds of the length of ventral side of claws. Siphunculi about .22.29 of body's length, very faintly smoky, with hardly darkened tips, smooth; largest diameter about 1.33 times the smallest more basad, and about twice the width of the mid-portions of the hind tibiae. Cauda rather thick, with almost parallel sides on basal half, blunt, .40-.57 of the siphunculi, with 8-13 hairs. (See table 1.)

Collection data. All from Stachys rigida; specimens nos. 1-6, Berkeley (Strawberry Canyon), Alameda County, California, March 29, 1964; specimens nos. 7-9 between Los Gatos and Santa Cruz, Santa Cruz County, California, April 5, 1964.

\section{Alate viviparous female}

In life. Abdomen as in apterae, but head and convex parts of mesonotum blackish brown. Siphunculi slightly smoky. Legs and antennae dusky, otherwise as in apterae.

In mounted specimens. Head and middle of mesonotum and metanotum dark smoky brown, vertex darker near lateral ocelli. Abdomen with faintly smoky marginal and pleural sclerites, sometimes with rather large sclerotic plates at the bases of the spinal hairs of tergites II-IV. Antennae slightly longer than in apterae, evenly smoky, with only base of segment III pale; segment III with about 26-35 rhinaria over its whole length. Wings with rather pale, smoky, normal venation. Legs slightly darker, otherwise as in apterae. Siphun-

3 The decimal fractions employed in statements of this kind have been converted from common fractions originally used by the author. He has kindly permitted us to make these conversions, but wishes to emphasize that a figure such as "1.33" (originally one and one-third) merely means an approximation, and is not to be interpreted as a precise comparison, down to the last decimal point. The decimals are used for the sake of better typographical appearance.-Editor 
TABLE 1

SAMPLE MEASUREMENTS OF AMPHOROPHORA STACHYOPHILA n. sp.

(Apterous Viviparous Females)

\begin{tabular}{|c|c|c|c|c|c|c|c|c|c|}
\hline \multirow{2}{*}{$\begin{array}{l}\text { Specimen } \\
\text { number }\end{array}$} & \multirow{2}{*}{$\begin{array}{l}\text { Body } \\
\text { length }\end{array}$} & \multirow{2}{*}{$\begin{array}{c}\text { Anten- } \\
\text { nae }\end{array}$} & \multicolumn{4}{|c|}{ Antennal segments } & \multirow{2}{*}{$\begin{array}{l}\text { Siphun- } \\
\text { culi }\end{array}$} & \multirow{2}{*}{ Cauda } & \multirow{2}{*}{$\begin{array}{l}\text { Rhinaria on } \\
\text { antennal } \\
\text { segments III }\end{array}$} \\
\hline & & & III & IV & $\mathbf{V}$ & VI & & & \\
\hline & 3.07 & 3.32 & 0.95 & 0.57 & 0.44 & $0.14+0.98$ & 0.75 & 0.36 & 15 and 22 \\
\hline $3 \ldots \ldots \ldots$ & 3.32 & 3.37 & 0.96 & 0.54 & 0.46 & $0.15+1.02$ & 0.79 & 0.43 & 14 and 14 \\
\hline $4 \ldots \ldots \ldots \ldots$ & 2.94 & 3.34 & 0.95 & 0.56 & 0.45 & $0.15+1.00$ & 0.79 & 0.40 & 12 and 13 \\
\hline $5 \ldots \ldots \ldots$ & 3.19 & 3.19 & 0.98 & 0.57 & 0.37 & $0.13+0.92$ & 0.71 & 0.42 & 18 and 27 \\
\hline $6 \ldots \ldots \ldots \ldots$ & 3.02 & 3.04 & 0.91 & 0.49 & 0.40 & $0.14+0.87$ & 0.73 & 0.39 & 11 and 13 \\
\hline $7 \ldots \ldots \ldots$ & 3.38 & 3.65 & 1.00 & 0.68 & 0.45 & $0.14+1.13$ & 0.82 & 0.35 & 14 and 24 \\
\hline $8 \ldots \ldots \ldots \ldots$ & 2.53 & 3.05 & 0.79 & 0.54 & 0.38 & $0.13+1.00$ & 0.68 & 0.29 & 22 and 23 \\
\hline
\end{tabular}

* Specimen no. 9 is the holotype.

culi smoky, slightly thinner than in apterae. Cauda tapering from base and not so blunt. Subgenital plate hardly smoky. (See table 2.)

Collection data. Specimens nos. 1 and 2 with apterae nos. 1-6; specimens nos. 3 and 4 with apterae nos. 7-9.

Notes. The species infests the stems and sometimes the undersides of the leaves of Stachys rigida, including subsp. quercetorum, growing in deep shadow. Exposed plants had no aphids, or only an occasional alate. On the north slope of the foot of Strawberry Canyon, Berkeley, considerable numbers were taken and larvae were reared to adulthood, while other samples were collected between Los Gatos and Santa Cruz under sequoias. Stachys bullata is prob- ably another host, according to specimens in the Essig collection that were not studied in great detail. Pink specimens in small numbers were taken at Berkeley in colonies of green ones.

This species is almost indistinguishable from Amphorophora rubitoxica Knowlton, which injures Rubus laciniatus and $R$. vitifolius. However, samples from these hosts from Vancouver, British Columbia, and from Berkeley, Inverness, and Napa County in California, all have only 16-22 hairs besides the 3 subapical pairs on the last rostral segment, while the empodial hairs are exactly as long as the line from claw tip to ventral claw base. All California $A$. rubitoxica that I collected had, as apterae, a light green color, with a brighter

TABLE 2

S AMPLE MEASUREMENTS OF AMPHOROPHORA STACHYOPHILA n. sp. (Alate Viviparous Females)

\begin{tabular}{|c|c|c|c|c|c|c|c|c|c|}
\hline \multirow{3}{*}{$\begin{array}{c}\text { Specimen } \\
\text { number }\end{array}$} & \multicolumn{8}{|c|}{ Sample measurements in $\mathrm{mm}$} & \multirow{3}{*}{$\begin{array}{l}\text { Rhinaria on } \\
\text { antennal } \\
\text { segments III }\end{array}$} \\
\hline & \multirow{2}{*}{$\begin{array}{c}\text { Body } \\
\text { length }\end{array}$} & \multirow{2}{*}{$\begin{array}{c}\text { Anten- } \\
\text { nae }\end{array}$} & \multicolumn{4}{|c|}{ Antennal segments } & \multirow{2}{*}{$\begin{array}{l}\text { Siphun- } \\
\text { culi }\end{array}$} & \multirow{2}{*}{ Cauda } & \\
\hline & & & III & IV & V & VI & & & \\
\hline $1 \ldots \ldots \ldots \ldots$ & 3.30 & 3.57 & 1.05 & 0.65 & 0.46 & $0.15+1.05$ & 0.66 & 0.36 & 26 and 27 \\
\hline $2 \ldots$ & 3.13 & 3.34 & 0.88 & 0.57 & 0.47 & $0.14+1.04$ & 0.68 & 0.35 & 28 and 28 \\
\hline $3 \ldots$ & 3.23 & 4.00 & 1.03 & 0.73 & 0.53 & $0.15+1.32$ & 0.75 & 0.31 & 30 and 30 \\
\hline $4 \ldots$ & 3.29 & 3.70 & 1.05 & 0.76 & 0.50 & $0.15+1.21$ & 0.75 & 0.32 & 31 and 34 \\
\hline
\end{tabular}


green median line down the dorsum, but the present species is evenly green.

Type material. Holotype: Apterous viviparous female (specimen no. 9 of measurements) from Stachys rigida quercetorum, between Los Gatos and Santa Cruz, Santa Cruz County, Cali- fornia, April 5, 1964, leg. H.R.L., no. 209. Paratypes: Alate and apterous females with data as for holotype, and from Stachys rigida, Berkeley (Strawberry Canyon), Alameda County, March 29, 1964, leg. H.R.L., nos. 192 and 198.

\section{Apbis avicularis (Hille Ris Lambers, 1931)}

A small, black aphid, with dark cauda and short, pale siphunculi; rather common on Polygonum aviculare in the streets (e.g., Oxford Street) of Berkeley, California, together with Aspida- phis adjuvans (Walker, 1848). Has been synonymized with Pergandeida polygonata Nevsky, 1929 (Börner, 1952), but Nevsky wrote in 1930 that his species had no reticulated dorsum.

\section{Aphis lugentis Williams, 1911}

A dull-black aphid with black legs, in Senecio, Berkeley, California, October very large colonies on cultivated, exotic $29,1963$.

\section{Atarsaphis agrifoliae (Ferris, 1921)}

I could not locate the types of Hamamelistes agrifoliae Ferris in the Stanford collection (now at Davis, California), but in the Essig collection there are specimens taken from the same tree as the types. Apparently, Atarsaphis quercus Takahashi, 1958, described from Quercus in Japan, is the same species, undoubtedly introduced from eastern Asia into California. A. quercus Takahashi, 1958, becomes a synonym of A. agrifoliae (Ferris, 1921).

\section{Braggia Gillette and Palmer, 1929}

Two species, $B$. echinata Gillette and Palmer, 1929, and B. uncompahgrensis Hottes, 1950, have been described as Braggia, and no further species have been placed in this genus. Characteristics of the genus are: six-segmented antennae, short processus terminalis, tapering siphunculi with wide flange, broad and very short cauda, heavy, spinelike dorsal hairs (Palmer, 1952). The presence of marginal tubercles on abdominal segments I and VII and the ventral position of those on VII show that the genus is very nearly related to Aphis Linnaeus. I should add that the dorsum is markedly reticulated, that the last rostral segment often has concave sides, with the longest hairs on the basal half, and that dark sclerotization (patchy or complete) of the abdominal tergum in apterae is common.

A study of Aphis-like aphids on Eriogonum reveals that all but the polyphagous Aphis craccivora Koch are strongly interrelated and should be placed in Braggia. The remarkable dorsal hairs are not nearly so pronounced in other species as in the two just named, and even may be lacking, but the other characters are present.

\section{Key to the Apterae of the Species and Subspecies of Braggia}

1(2). Dorsum with very thick, hollow hairs, which at their base are over $0.006 \mathrm{~mm}$ thick, and which are placed on processus-like sockets over 0.013 $\mathrm{mm}$ high.

Braggia echinata Gillette and Palmer, s. $l$.

a (b). Hairs about cylindrical, with rounded apices, less than $0.045 \mathrm{~mm}$ long; all dorsal rows on abdominal segments II-IV duplicated, so that on each 
of these segments 12 or more thick hairs are present; the spinal pairs are sometimes triplicated. On Eriogonum umbellatum. Colorado.

Subsp. echinata Gillette and Palmer, s. s.

$b$ (a). Hairs distinctly tapering, often into a rather thin if blunt point, up to more than $0.10 \mathrm{~mm}$ long; only the spinal and marginal rows duplicated, so that each of abdominal segments II-IV has 10 hairs. On Eriogonum corymbosum. Colorado.

Subsp. uncompahgrensis Hottes

2(1). Dorsal hairs often stout, but much thinner and usually rather acute, on rather normal sockets.

$3(4)$. Dorsal hairs inconspicuous, at most as long as basal diameter of antennal segment III. Siphunculi at most as long as their basal width. Hairs on outside of mid-portion of hind tibiae mostly less than half local width of those tibiae. Marginal tubercles on abdominal tergite VII normally absent. In life, nude and shiny.

Braggia deserticola n. sp., s. $l$.

a (b). Legs completely or nearly black, with basal half of hind tibiae at most transparent brown. Last rostral segment 1.17-1.40 times as long as second joint of hind tarsi, longer than basal part of last antennal segment. On Eriogonum fasciculatum. California. Subsp. deserticolan. subsp.

$\mathrm{b}(\mathrm{a})$. Tibiae pale yellowish, with black socks. Last rostral segment 1.00-1.33 times second joint of hind tarsi, subequal to basal part of last antennal segment. On Eriogonum sp. California.

Subsp. thanatophila n. subsp.

4(3). Dorsal hairs sometimes not, or hardly, longer than basal diameter of antennal segment III, but then siphunculi much longer than their basal width, and besides secondary rhinaria rarely present; dorsal hairs usually quite long and stout, particularly if the siphunculi are not longer than their basal width. Hairs on outer side of hind tibiae short or long. Marginal tubercles on abdominal tergite VII small but distinct.

5(6). Cauda much shorter than its basal width. Siphunculi very strongly tapering, and also with a very wide flange which is about 1.25-1.50 times as wide as smallest width of the siphunculi. Antennal segments III, IV, and often $\mathrm{V}$ mostly with rhinaria. Dorsal hairs stout, and some up to more than twice basal diameter of antennal segment III.

Braggia eriogoni (Cowen) (n. comb.), s.l.

a(b). Hairs on outer side of all tibiae erect, or very nearly so, with fine and wavy points, those on the mid-portion of the hind tibiae up to $0.07 \mathrm{~mm}$ long, longer than the local diameter of those tibiae. Tergum often entirely black-sclerotic, but in small specimens sclerotic in patches. On Eriogonum sp. Wyoming.

Subsp. atra n. subsp.

$\mathrm{b}$ (a). Tibial hairs drooping, at about $60^{\circ}$ to the tibiae, stiff, slightly curved, from blunt to acuminate, on the mid-portion of the hind tibiae not quite so-long as the local width of the tibiae.

c(d). Siphunculi longer than second joint of hind tarsi; about 1.60-2.00 times as long as their basal width. Hairs on outer side of mid-portion of hind tibiae blunt or semi-blunt, not more than seven-tenths of the local diameter of those tibiae. On various Eriogonum spp. (E. umbellatum at Eldora, Boulder County, Colorado). 
$d(c)$. Siphunculi shorter than second joint of hind tarsi, mostly less than 1.5 times as long as their basal width. Hairs on hind tibiae variable.

e(f). Hairs on antennal segment III all shorter than diameter of mid-portion of the segment, mostly blunt. First tarsal joints of all legs with 2 hairs. Siphunculi tapering, with rather straight sides, less than twice as wide at base as they are at their smallest width. On Eriogonum corymbosum. Colorado.

Subsp. agathona (Hottes) n. comb.

$f(e)$. At least one of the hairs on antennal segment III as long as or longer than width of mid-portion of the segment, mostly acute. First tarsal joints of fore- and mid-legs normally with 3 hairs. Siphunculi very strongly tapering, very wide at base, 2-3 times the narrowest width near apex, with the sides mostly conspicuously convex. On Eriogonum arborescens, $E$. fasciculatum, its var. polifolium, and $E$. sp. California.

Subsp. californica n. subsp.

6(5). Cauda about as long as or slightly longer than its basal width. Siphunculi sometimes strongly tapering, but always also thick at apex, and with a very small flange of not more than 1.12 times the minimum width of the siphunculi. Antennal segments III and IV only exceptionally with a rhinarium. Dorsal hairs not very long, mostly very blunt, and not often up to twice basal diameter of antennal segment III.

Braggia urovaneta (Hottes) (n. comb.), s.l.

a(b). Last rostral segment about $0.145-0.175 \mathrm{~mm}$ long, about $1.29-1.50$ times as long as second joint of hind tarsi, 2.33-2.67 times basal width of siphunculi. On Eriogonum corymbosum (?). Colorado.

Braggia urovaneta (Hottes), s. s.

$\mathrm{b}(\mathrm{a})$. Last rostral segment shorter, 0.11-0.135 mm long, 0.93-1.20 times second joint of hind tarsi, 1.20-2.00 times basal width of the thicker siphunculi. On Eriogonum latifolium and its subsp. nudum. California.

Subsp. pachysiphon n. subsp.

\section{Braggia deserticola n. sp., s. l.}

\section{Apterous viviparous female}

1. Subsp. deserticola n. subsp.

In life. Dorsally rather to very shiny black, ventrally gray with wax powder, with all appendages black.

In mounted specimens. Body Brachycaudus-like, rather broadly oval and slightly depressed, about 1.10-1.80 mm long. Abdominal tergum is blackish, sclerotic; in the extreme cases either quite membranous, or in the largest specimens with one shield that includes even the stigmata, the metanotum, and abdominal tergite VI, and that has a suture between V and VI; usually with only much perforated and corrugated fragments of such a shield, with most fragments being found on tergites III and IV; the sclerotic parts very markedly reticulated. Dorsal hairs almost Aphis-like, thorny and very acute, up to about as long as basal diameter of antennal segment III. Small marginal tubercles present on abdominal segment I, but apparently not on VII. Head with conspicuously sinuated front, often with very small frontal tubercles. Antennae black, with only basal .20-.50 of segment III transparent to yellowish, about .62-.67 of length of body, with imbricated flagellum; segment III with 1-8 (rarely 0) rhinaria, usually only on distal half, IV with 2-7 rhinaria, and V with $0-1$ secondary ones; interrelations 
TABLE 3

SAMPLE MEASUREMENTS OF BRAGGIA DESERTICOLA n. sp.

(Apterous Viviparous Females)

\begin{tabular}{|c|c|c|c|c|c|c|c|c|c|c|c|}
\hline \multirow{3}{*}{$\begin{array}{c}\text { Speci- } \\
\text { men } \\
\text { num- } \\
\text { ber }\end{array}$} & \multicolumn{8}{|c|}{ Sample measurements in $\mathrm{mm}$} & \multicolumn{3}{|c|}{ Rhinaria on antennsl segments } \\
\hline & \multirow{2}{*}{$\begin{array}{l}\text { Body } \\
\text { length }\end{array}$} & \multirow{2}{*}{$\underset{\text { nae }}{\text { Anten- }}$} & \multicolumn{4}{|c|}{ Antennal segments } & \multirow{2}{*}{$\begin{array}{l}\mathrm{Si-} \\
\text { phun- } \\
\text { culi }\end{array}$} & \multirow{2}{*}{ Cauda } & \multirow{2}{*}{ III } & \multirow{2}{*}{ IV } & \multirow{2}{*}{$\mathrm{V}$} \\
\hline & & & III & IV & $\mathrm{v}$ & VI & & & & & \\
\hline & 1.77 & 1.11 & 0.34 & 0.21 & 0.18 & $0.12+0.14$ & 0.05 & 0.09 & 4 and 3 & 5 and 5 & 1 and 0 \\
\hline $2 \ldots \ldots \ldots$ & 1.61 & 1.06 & 0.31 & 0.20 & 0.18 & $0.11+0.14$ & 0.05 & 0.08 & 3 and 5 & 4 and 4 & 1 and 0 \\
\hline 3......... & 1.68 & 1.05 & 0.30 & 0.18 & 0.18 & $0.12+0.14$ & 0.05 & 0.08 & 6 and 6 & 6 and 4 & 0 and 1 \\
\hline $4 \ldots \ldots$. & 1.60 & 1.19 & 0.33 & 0.25 & 0.20 & $0.13+0.15$ & 0.05 & 0.06 & 8 and 5 & 4 and 5 & 1 and 1 \\
\hline $5 \ldots \ldots$ & 1.66 & 1.05 & 0.33 & 0.19 & 0.16 & $0.12+0.16$ & 0.03 & 0.06 & 3 and 4 & 3 and 4 & 0 and 0 \\
\hline $6 \ldots \ldots \ldots$ & 1.13 & 0.75 & 0.18 & 0.13 & 0.13 & $0.10+0.11$ & 0.03 & 0.05 & 1 and 1 & 2 and 2 & 0 and 0 \\
\hline
\end{tabular}

- Specimen no. 1 is the holotype.

of segments see measurements; longest hair on segment III about .50-.62 of basal diameter of the segment. Rostrum reaching the hind coxae; last segment elongate, with concave sides, with 2 hairs on the basal half that are twice as long as any of the 6 subapical hairs, of which one pair stands rather far basad from the other two. Legs rather long, very dark pigmented, mostly black but sometimes with a considerable part of particularly the fore and the middle tibiae rather pale to yellowish; hairs on the outer side on mid-portion of hind tibiae like the hairs on antennal segment III, or slightly longer; first tarsal joints of all legs with 2 hairs. Siphunculi volcano-shaped to strongly tapering in dorsal view, normally shorter than their basal width, with the outer side concave, the inner side convex, with a rather small flange, and with more or less smooth surfaces; their basal circumference strongly transversely oval (as in $B$. eriogoni), which accounts for a great variation in shape in mounts. Cauda black, very broad, in purely dorsal view triangular, with strongly convex sides, and half as long as its basal width, with very numerous, some 7-11, rather inconspicuous hairs, mostly on the underside. (See table 3.)

Collection data. Specimens nos. 1 and 2, Riverside, Riverside County, California, January 14, 1964, leg. R. C. Dickson and H.R.L., no. 117; specimens nos. 3, 4, and 6, Aguanga, Riverside County, California, January 17, 1964, leg. R. C. Dickson and H.R.L., no. 131; specimen no. 5, Julian, San Diego County, California, January 17, 1964, leg. R. C. Dickson and H.R.L., no. 133.

\section{Alate viviparous female}

In life. Black dorsally, grayish ventrally.

In mounted specimens. Abdomen with rather large, darkish, marginal sclerites, sharply bordered, glandlike pleural intersegmental sclerites, often some rather vague spinal sclerites on tergites III, IV, or V or on all of these, and usually irregular, dusky, rather narrow bars across tergites VI, VII, and VIII. Antennae with only the very base of segment III somewhat transparent; segment III with 9-16 flattish rhinaria in a row that is duplicated here and there, IV with 3-6 rhinaria, V with $0-4$. Legs black. Wings with pale, normal venation. Siphunculi much less tapering and much narrower at base than in apterae. Cauda slightly narrower and therefore seemingly longer than in apterae. (See table 4.)

Collection data. Specimens nos. 1 and 2 with apterae nos. 1 and 2 ; specimens nos. 3 and 4 with apterae nos. 3 , 4, and 6 ; specimen no. 5 with aptera no. 5 . 
TABLE 4

SAMPLE MEASUREMENTS OF BRAGGIA DESERTICOLA n. sp.

(Alate Viviparous Females)

\begin{tabular}{|c|c|c|c|c|c|c|c|c|c|c|c|}
\hline \multirow{3}{*}{$\begin{array}{c}\text { Speci- } \\
\text { men } \\
\text { num- } \\
\text { ber }\end{array}$} & \multicolumn{8}{|c|}{ Sample measurements in $\mathrm{mm}$} & \multicolumn{3}{|c|}{ Rhinaria on antennsl segments } \\
\hline & \multirow{2}{*}{$\begin{array}{c}\text { Body } \\
\text { length }\end{array}$} & \multirow{2}{*}{$\begin{array}{c}\text { Anten- } \\
\text { nae }\end{array}$} & \multicolumn{4}{|c|}{ Antennal segments } & \multirow{2}{*}{$\underset{\text { phun- }}{\text { Si- }}$} & \multirow{2}{*}{ Cauda } & \multirow{2}{*}{ III } & \multirow{2}{*}{ IV } & \multirow{2}{*}{ V } \\
\hline & & & III & IV & $\mathrm{v}$ & vI & & & & & \\
\hline & 1.51 & 1.00 & 0.31 & 0.18 & 0.15 & $0.12+0.14$ & 0.05 & 0.09 & 15 and 14 & 6 and 4 & 1 and 1 \\
\hline & 1.45 & 1.06 & 0.34 & 0.19 & 0.16 & $0.12+0.15$ & 0.04 & 0.06 & 10 and 11 & 5 and 5 & 1 and 2 \\
\hline $3 \ldots \ldots$ & 1.72 & 1.27 & 0.38 & 0.22 & 0.21 & $0.14+0.17$ & 0.04 & 0.08 & 12 and 10 & 6 and? & 2 and? \\
\hline & 1.32 & 1.05 & 0.30 & 0.19 & 0.17 & $0.11+0.14$ & 0.04 & 0.06 & 10 and 13 & 5 and 4 & 1 and 2 \\
\hline $5 \ldots$ & 1.63 & 1.23 & 0.38 & 0.23 & 0.19 & $0.13+0.18$ & 0.04 & 0.08 & 15 and 13 & 4 and 6 & 2 and 4 \\
\hline
\end{tabular}

Notes. The aphid was found in the inflorescences of Eriogonum fasciculatum, including its subsp. polifolium, mostly in rather small numbers. Braggia eriogoni subsp. californica was common, often in larger numbers, on the same plants but could be easily distinguished because of its waxiness. $B$. $d e-$ serticola as a larva is deep chestnut brown. The colonies were not attended by ants. Because of the presence of only 2 hairs on the first tarsal joints, a relationship to $B$. eriogoni agathona is suggested, but there the resemblance stops. Because of the chaetotaxy of the last rostral segment, $\boldsymbol{B}$. deserticola can be placed with certainty in Braggia, but not because of its dorsal hairs. The shapes of the siphunculi and cauda confirm the relationship to $B$. echinata and the other species that I placed in Braggia.

Type material. Holotype: Apterous viviparous female (specimen no. 1 of measurements) from Eriogonum fasciculatum, Riverside, Riverside County, California, January 14, 1964, leg. R. C. Dickson and H.R.L., no. 117. Paratypes: Apterae and alatae with the same data as for holotype, but from Aguanga, Riverside County, California, January
17, 1964, leg. R. C. Dickson and H.R.L., no. 131; and Julian, San Diego County, California, January 17, 1964, leg. R. C. Dickson and H.R.L., no. 133.

2. Subsp. thanatophila n. subsp. A small sample collected by $R$. van den Bosch, consisting of 3 apterae and 1 alata from an unidentified Eriogonum, differs from the true deserticola by having considerably shorter dorsal, frontal, and antennal hairs. The siphunculi can hardly be measured, but are certainly not half as long as their basal width. The legs of both morphs have quite black femora, but all tibiae are light yellow, with black socks. The hairs on basal half of last rostral segment are not more than 1.50 times as long as the longest hair more distad; that segment is distinctly shorter than it is in the other samples of $\boldsymbol{B}$. deserticola. For these reasons, the mentioned sample is considered to belong to a distinct subspecies.

Type material. Holotype: Apterous viviparous female from Eriogonum sp., 7 miles east of Big Pine, Inyo County, California, 6,100 feet, July 16, 1961, leg. R. van den Bosch, no. 61-7-16h. Paratypes: 2 apterae and 1 alata in the same slide.

\section{Braggia eriogoni (Cowen, 1895), s. l.}

1. Subsp. agathona (Hottes, 1950). Paratypes of Aphis agathona Hottes from Eriogonum corymbosum were remounted. The tergum in apterae viviparae has only some local sclerites on

the disc of the abdomen; the siphunculi do not taper strongly, but they are constricted just below the small flange. Palmer (1952, pp. 121 and 122) states that the hairs are short and inconspic- 
uous, but I find the dorsal hairs to be very stout, pointed, and on abdominal tergites II-IV up to 3.50 times as long as the basal diameter of antennal segment III, in contrast to the hairs on antennal segment III, which are just blunt and up to as long as the mentioned diameter. All the specimens have only 2 hairs on the first tarsal joints of the fore- and mid-legs, in contrast to the other subspecies. The single pair of hairs on the basal half of the long and thin last segment of the rostrum are more than twice as long as the hairs near the apex. In the key of Palmer's book (1952, p. 120), agathona is separated from eriogoni by the length of the processus terminalis; in eriogoni, being $0.16 \mathrm{~mm}$ or over; in agathona, shorter than 0.16 ; but in my 4 paratypes of agathona, the length varies from 0.130 to $0.174 \mathrm{~mm}$. The slender shape of the subspecies, mentioned as a chief distinguishing character, was certainly present in the balsam slide of the paratypes, but this was an artifact.

2. Subsp. eriogoni (Cowen, 1895). Specimens identified by M. A. Palmer as Aphis eriogoni Cowen from Eriogonum umbellatum, Eldora, Boulder County, Colorado, June 25, 1911, leg. L. C. Bragg, may well be typical as to host species. Characteristic of the apterae is the almost complete black sclerotization of the abdomen and thorax, and the stout but acuminate or blunt dorsal hairs of up to 1.50-1.60 times the basal diameter of antennal segment III, while some of the hairs on that antennal segment are longer than that diameter. The bases of the rather long, quite black and rough siphunculi are 2 or more times as thick as the apices. The first tarsal joints of fore- and mid-legs have 3 hairs each, the middle hair being just over half as long as the lateral ones.

3. Subsp. atra n. subsp. Two samples from Wyoming look very different from each other, but the variability of specific characters is not great. The subspecies closely resembles eriogoni proper, but the hairs on antennae and legs are very much longer, and erect or very nearly so, though the dorsal hairs are as in eriogoni. The longest hair on segment III is 2 or more times as long as the basal diameter of the segment, and the other hairs are hardly shorter. The strongly tapering black siphunculi are about as long as their basal width, and considerably shorter than the second joint of the hind tarsi.

Type material. Holotype: Apterous viviparous female from Eriogonum sp., Centennial, Albany County, Wyoming, August 12, 1957, leg. G. F. Knowlton. Paratypes: Apterae and alatae viviparae, with data as for holotype, and apterae viviparae from unidentified host, Yellowstone Canyon, Wyoming, August 25, 1955, leg. G. F. Knowlton.

4. Subsp. californica n. subsp. This subspecies resembles subsp. atra very much, but the hairs on antennae and tibiae in all the several samples are considerably shorter and rather like subsp. eriogoni (Cowen). However, the siphunculi are always quite short and not, or hardly, longer than their basal width and shorter than second joint of hind tarsi. The middle hair on the first tarsal joints of the mid-legs is sometimes absent, but not that on the forelegs. In California, the subspecies is widely spread. We found it at Berkeley, Alameda County, on Eriogonum arborescens and Eriogonum sp.; and at Julian, San Diego County, and Temecula, Riverside County, on $\boldsymbol{E}$. fasciculatum. I could not find it on $E$. latifolium.

Type material. Holotype: Apterous viviparous female from Eriogonum arborescens, Berkeley (U. C. Botanical Garden), Alameda County, California, February 2, 1964, leg. H.R.L., no. 142. Paratypes: Apterous and alate females with data as for holotype, but from Eriogonum fasciculatum, 3 miles north of Temecula, Riverside County, California, January 17, 1964, leg. H.R.L., no. 132; and Julian, San Diego County, California, January 17, 1964, leg. H.R.L., no. 133. 


\section{Braggia urovaneta (Hottes, 1950), s. l.}

1. Subsp. urovaneta (Hottes, 1950). Type material was not available, but $\mathrm{F}$. C. Hottes and H.R.L. collected many sexuals from Eriogonum corymbosum at the type locality, and this material could be compared with sexuals collected elsewhere. The insect, as regards structure of antennae, rostrum (last segment long, with concave sides, and with the 2 hairs on basal half twice as long as the subapical hairs), reticulated dorsum, dorsal hairs, etc., is a Braggia, but the siphunculi have a slightly different shape, the cauda is more slender than in other species, and antennal segment III in apterae very rarely has rhinaria.

The most important character in which the species differs from other species of Braggia is in the sclerotization. In the others, reduction of sclerotization of the abdominal tergum (as in oviparae) leads to sclerites on the center of the dorsum, but in urovaneta the last sclerites to remain are pleuromarginal in front of each siphunculus.

2. Subsp. pachysiphon n. subsp. The California material that can be placed in $B$. urovaneta is very homogeneous. The dorsal hairs, both rather short and acuminate, are scarcely longer than the basal diameter of antennal segment III, and the hairs on that segment are quite short, only .40-.50 of that diameter. The abdominal sclerotization in apterae viviparae at a maximum consists of an often pale-smoky to dark spinopleural shield, but usually consists of a solid bar across tergites IV and $\mathrm{V}$, with variable extensions or an archipelago of smaller sclerites cephalad. In life, the aphids are black, with a layer of gray powder which, on the disc of the abdomen, is very thin.

The oviparae of this subspecies differ especially from those of the main species in having a much shorter last rostral segment (although with the same chaetotaxy), much thicker and longer siphunculi, and much less swollen hind tibiae. Siphunculi shorter than basal part of antennal segment VI, mentioned as a chief distinguishing character by Palmer (1952, p. 182) for the main species, were very rarely found in California material, nor was it true in oviparae of the main species from the type locality. The front of alatae is unusually protruding, but in California specimens not nearly so much as in Palmer's figures. Differences between the subspecies are given in my key.

This subspecies would seem to be rather host-specific. In a group of closely related Eriogonum species in the U. C. Botanical Garden at Berkeley, $\boldsymbol{E}$. latifolium was smothered with aphids, but other species of Eriogonum that were growing alongside had none. In nature we could find the species only on $E$. latifolium subsp. nudum, first on the radical leaves, later on the stems, in dense colonies.

Type material. Holotype: Apterous viviparous female from Eriogonum latifolium, Berkeley (U. C. Botanical Garden), Alameda County, California, October 30, 1963, leg. H.R.L., no. 48. Paratypes: Apterous viviparous females, alate viviparous females, oviparae with the data of the holotype, as well as apterae and alatae from $E$. latifolium subsp. nudum, 7 miles west of Frazier Park, Kern County, California, July 17, 1958, leg. R. C. Dickson; various places near Lake Berryessa, Napa County, California, March 17, 1964, leg. H.R.L., no. 178.

\section{Chaitophorus eoessigi n. sp.}

\section{Apterous viviparous female}

In life. Extremely variable, so that colonies look like mixtures of two or three species. As larvae, with an apple- green lyre-shaped pattern on buff background; in adults, the lyre pattern darker to black, and finally only a pale median line left; old specimens both 
TABLE 5

SAMPLE MEASUREMENTS OF CHAITOPHORUS EOESSIGI n. sp. (Apterous Viviparous Females)

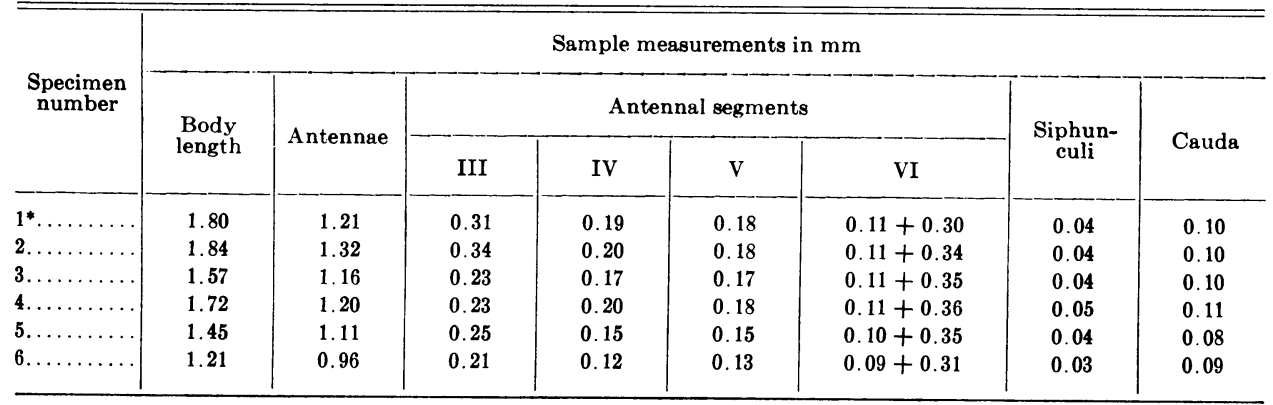

* Specimen no. 1 is the holotype.

dorsally and ventrally darker; femora in larvae and adults from California very dark, strongly contrasting to the body in apple-green forms; Mexican specimens also with their femora lighter.

In mounted specimens. Body pearshaped, depressed, 1.15-1.90 mm long; the pigmentation with much variation, with the head, coxae, trochanters, femora, and small areas near the coxae dark to very dark, but the rest of the body varying from almost colorless, to smoky, with darker, vaguely bordered pleural spots, to rather evenly blackish brown, with a pale median zone from head to abdominal segment III and with darker dotted intersegmental rows of spots; the pigmentation quite often very asymmetrical, but always completely absent around the siphunculi. Integument seemingly smooth, but under high magnification with rather disperse, small, flat nodules that are not arranged in a pattern. Dorsal hairs long, on abdominal tergite III up to 4 or 5 times as long as basal diameter of antennal segment III, with not very thick, slightly widened, furcated or serrated tops; but those on tergites VII, and the 6-9 hairs on VIII, all or partly with acute tops. Antennae .67-.80 of length of body, slightly imbricated, with the basal segments dark to black, the flagellum varying from pale up to the apical one-fourth part of segment $V$ in pale specimens, to blackish, with only the base of segment III pale in darl: specimens; hairs on segment III on inner side long, in dark specimens the longest, over twice the basal diameter of the segment, stiff, with just blunt or furcated thin apices, not numerous, on outer side near apex with one or two stiff hairs that are often shorter than basal diameter of antennal segment III; but in pale specimens the longest hair is 1.50 times that diameter; base of segment VI usually with 2 hairs that are equally long in pale specimens, about equal to the basal diameter of antennal segment III, but in dark specimens the inner-side hair is 1.75 times as long as the one on the side that has the rhinaria. Rostrum reaching to or past the middle coxae; last segment moderately long, very nearly as long (.90-.95) as second joint of hind tarsi, with 2 hairs besides the 3 subapical pairs, one of which is placed rather far basad. Femora dark to black, with extreme bases pale, thick, with two markedly curved apical hairs that have thicker apices than the other femoral hairs; tibiae pale vellow, with dark basal .17-.25 part and black socks; first tarsal joints mostly with 5 hairs, but (especially in large specimens) nearly always with 6 hairs on some joints, so that specimens should occur with 6 or 7 hairs on all legs. Siphunculi normally evenly pale, but in dark specimens with a dusky apex, always placed 
on a pale area, cylindrical to tapering, quite short, about as long as their halfway width, reticulated on distal .50-.60 part. Cauda short, pale, with an almost perfectly globular knob. (See table 5.)

Collection data. Specimens nos. 1 and 2, Riverside, Riverside County, California, January 14, 1964, leg. R. C. Dickson and H.R.L., no. 121; specimens nos. 3 and 4, state of Nayarit, Mexico, February 3, 1964, leg. R. van den Bosch, no. 64-2-3b; specimens nos. 5 and 6, 49 miles east of Villa Unión, Sinaloa, Mexico, February 1, 1964, leg. R. van den Bosch, no. 64-2-1i.

\section{Alate viviparous female (from one specimen)}

In mounted specimen. Abdomen with dark, mutually quite free, spinopleural transverse bars on each of tergites IVIII. Most dorsal hairs acute, a very few with fine, just furcated apex. Antennal segment III on distal threefourths part with small and inconspicuous rhinaria. Siphunculi dark, much longer than in apterae and almost completely reticulated to the pale base. Wings with normal, rather pale venation, and also with stigma hardly pigmented. The rest as noted under apterae. (See table 6.)

Collection data. State of Nayarit, Mexico, February 3, 1964, leg. R. van den Bosch, no. 64-2-3b.

\section{Larvae}

Two distinct types of larvae occurred in the colonies: specimens with very dark antennae and black sclerites at the bases of the dorsal hairs; and larvae with apically dark antennae, with or without nonpigmented sclerites at the bases of the dorsal hairs.

Notes. This very curious Chaitophorus has been found several times before, both in southern California and in Mexico, according to material in the Essig collection. The pale and the dark

\section{TABLE 6}

SAMPLE MEASUREMENTS OF

CHAITOPHORUS EOESSIGI n. sp.

(Alate Viviparous Female-Single Specimen)

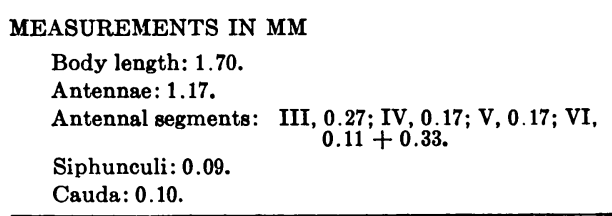

Number of rhinaria on antennal segments III: 5 and 6.

apterae differ in length of antennal hairs and, as such differences are also found between the larvae without sclerites and those with blackish dorsal sclerites, it seems that the differences in pigmentation may have a genetic basis. The species cannot be keyed with the key to North American Chaitophorus that I published in 1960 (Hille Ris Lambers, 1960), because that was made for species with a rather constant chaetotaxy of the first tarsal joints and some constancy in pigmentation. Dark specimens with predominantly 5 hairs on the first tarsal joints key to $C$. longipes Tissot, but in the latter species the last rostral segment is longer than the second joint of the hind tarsi and it has 10 or more hairs. Pale specimens with 5 or 7 hairs on the first tarsal joints cannot be keyed at all. C. eoessigi is almost certainly closely related to $C$. longipes Tissot and $C$. viminicola Hille Ris Lambers, but it differs from both of these in the chaetotaxy and blunter shape of the last rostral segment. It lives both on the upper and undersides of the leaves of Salix sp., mostly on the apical half of the leaf, and is not attended by ants.

Type material. Holotype: Apterous viviparous female (specimen no. 1 of measurements) from Salix sp., Riverside, Riverside County, California, January 14, 1964, leg. R. C. Dickson and H.R.L., no. 121. Paratypes: Apterous viviparous females with the same data as for holotype. 


\section{Chaitophorus populialbae (Fonscolombe, 1841)}

The only North American record (Hille Ris Lambers, 1960, p. 7) was from Fredericton, N.B.; but it was also found on Populus alba at Berkeley. It hibernates as eggs. Both sexuals and fundatrix were collected.

\section{Corylobium vandenboschi $\mathrm{n}$. sp.}

\section{Apterous viviparous female}

In life. Light green. Antennae mostly light brown, but black toward tip. Eyes black. Legs light brown, with black tarsi. Apical two-thirds of siphunculi black, the rest brown.

In mounted specimens. Rather elongated oval, with very strongly sclerotic but quite pale, strongly wrinkled or corrugated tergum. Dorsal hairs rather thick and stiff, with incrassate, elongated oval apices, placed on moderately stout sockets but not on dorsal processi; hairs numerous, on abdominal tergites II and III, 13-17 in number, about 0.04 $\mathrm{mm}$ long, sometimes with a few short ones of only half that length; tergite VIII with about 8 hairs up to about $0.06 \mathrm{~mm}$ long. Marginal tubercles on tergites II-IV small, knobbed, with globular distal part; similar spinal tubercles on vertex and abdominal tergite VIII irregularly present. Head smooth, vertex not wrinkled; frontal tubercles moderately developed, diverging; median tubercle absent or inconspicuous. Antennae much longer than body; the flagellum thick-walled, pale brownish yellow, with the tips of segments III, IV, and V, and the whole segment VI blackish brown; gradually more distinctly imbricated from the middle of segment IV toward apex; segment III near base with 1 or 2 smallish, not bulging, rhinaria; hairs on segment III similar to the body's hairs, but smaller, up to about half the basal diameter of the segment. Rostrum reaching the hind coxae, conspicuously hairy; apical segment long, about 1.80 times as long as second joint of hind tarsi, with about 18-22 hairs besides the 3 subapi- cal pairs. Legs smooth, pale brownish yellow, with blackish apices to the tibiae, and a more or less faint, smoky pigmentation of the basal portion of the tibiae; hairs on dorsal side of tibiae like those on antennal segment III, shorter than those on ventral side; first tarsal joints with $3,3,3$ hairs; second joints with some very indistinct spinules on the dorsal imbrications. Siphunculi about two-sevenths of length of body, with pale basal .40-.50 part and rather sharply defined dark distal portion, on distal half more or less cylindrical and about 1.33 times as thick as the midportion of the hind tibiae, but at base twice as thick as in the middle, gradually tapering toward the middle; surface on basal half faintly and very dispersely imbricated, but distal half distinctly imbricated, with 5-6 rows of rather coarse reticulations on apical .08-.10 part; flange rather large. Cauda pale, rather thick, with a faint constriction, semi-blunt, about one-third the length of the siphunculi, with 6-7 hairs. (See table 7.)

Collection data. Specimens nos. 1 and 2 from Corylus cornuta var. californica, Camp Nelson, Tulare County, California, July 13, 1961, leg. R. van den Bosch and E. Schlinger, no. 61-7130.

Notes. Two slightly damaged specimens were received from their collectors, but there are others in the Essig collection from the same host plant. By the variolous, strongly sclerotic tergum of the apterae viviparae, the species can easily be separated from the other $M a c$ rosiphum-like aphid that has been described from American Corylus spp., Macrosiphum coryli Davis, 1914. 
TABLE 7

SAMPLE MEASUREMENTS OF CORYLOBIUM VANDENBOSCHI n. sp.

(Apterous Viviparous Females)

\begin{tabular}{|c|c|c|c|c|c|c|c|c|c|}
\hline \multirow{3}{*}{$\begin{array}{c}\text { Specimen } \\
\text { number }\end{array}$} & \multicolumn{8}{|c|}{ Sample measurements in mm } & \multirow{3}{*}{$\begin{array}{c}\text { Rhinaria on } \\
\text { antennal } \\
\text { segments III }\end{array}$} \\
\hline & \multirow{2}{*}{$\begin{array}{c}\text { Body } \\
\text { length }\end{array}$} & \multirow{2}{*}{$\begin{array}{c}\text { Anten- } \\
\text { nae }\end{array}$} & \multicolumn{4}{|c|}{ Antennal segments } & \multirow{2}{*}{$\underset{\text { culi }}{\text { Siphun- }}$} & \multirow{2}{*}{ Cauda } & \\
\hline & & & III & IV & $\mathrm{v}$ & VI & & & \\
\hline $1 *$. & 2.11 & 3.11 & 0.72 & 0.61 & 0.53 & $0.13+0.94$ & 0.64 & 0.21 & 1 and? \\
\hline $2 \ldots \ldots \ldots \ldots$ & 2.19 & $?$ & 0.76 & 0.62 & 0.62 & $0.13+?$ & 0.64 & 0.22 & 2 and 2 \\
\hline
\end{tabular}

* Specimen no. 1 is the holotype.

With my key to Macrosiphum-like genera that was published in 1958 (see MacGillivray, 1958), this species cannot be easily identified. Couplets $3(4)$ and 4(3) have to be changed as follows:

3(4). Abdominal tergum in apterae thickly sclerotic, pale, markedly variolous. Dorsal hairs sometimes placed on large processi or tubercles. Corylobium Mordvilko, 1914

4(3). Abdominal tergum in apterae sometimes sclerotic, but not variolous. Dorsal hairs not on large processi or tubercles.

The genus Corylobium had only one species, C. avellanae (Schrank, 1801), in which the dorsal hairs in apterae are placed singly or in pairs on conspicuous elevations of the papillate to vario- lous integumentum. In the present species the dorsum is more particularly wrinkled, the hairs are not placed on protuberances, and are much shorter. In most other respects the species are quite similar.

The new species is named for one of its collectors who, by his methodical and very careful collecting in various parts of the world, has made the solution of many taxonomic and biological problems possible.

Type material. Holotype: Apterous viviparous female (specimen no. 1 of measurements) from Corylus cornuta var. californica, Camp Nelson, Tulare County, California, July 13, 1961, leg. R. van den Bosch and E. Schlinger, no. 61-7-13o. Paratype: Apterous female with data as for holotype.

\section{Dactynotus acbilleae (Koch, 1855)}

Very large colonies of this European species, which previously had not been found in North America, were encountered on Achillea sp. growing under a
Cupressus macrocarpa in the dunes south of Fleishhacker Zoo, San Francisco. It infests the lower leaves which, at the tips, wither and turn brown.

\section{Dactynotus (Uromelan) bonitus (Hottes, 1950)}

Some specimens were collected from the typical host, Stephanomeria pauciflora, 8 miles east of Big Pine, Inyo
County, California (6,300 feet), July 16,1961 , leg. R. van den Bosch, no. 617-16j.

\section{Dactynotus erigeronensis (Thomas, 1877), s. l.}

Material of this complex from California would seem to belong to three different taxa. Macrosiphum erigeronella Soliman, 1928, was described from a slide from Erigeron (syn. Conyza) canadensis at Berkeley, in the Essig collection; a slide that, according to a note in Essig's handwriting, has long since 
disappeared. Soliman distinguishes his species from erigeronensis Thomas by the length of the siphunculi: $0.75 \mathrm{~mm}$ in erigeronensis, $1.00 \mathrm{~mm}$ in erigeronella. Since even in one sample of erigeronensis (e.g., Brickellia sp., Rincon Springs, San Diego County, California, leg. R. van den Bosch, no. 61-2-14c), an ovipara has siphunculi of $1.00 \mathrm{~mm}$, but an aptera vivipara of the same size, $0.79 \mathrm{~mm}$, such a discriminant based on length of siphunculi is not very helpful, and thus erigeronella Soliman is considered a synonym of erigeronensis Thomas (cf. escalantii Knowlton, 1928). The siphunculi in apterae are much longer than antennal segment III; gradually darker from base to apex, but never blackish; the tibiae are not black; the apterae have about 10 to 18 rhinaria on antennal segment III, while the alatae have about 20 to 35 .

A form in which apterae have the siphunculi well over 1.00 (1.06-1.20) $\mathrm{mm}$ long, blackish, with the exception of the pale basal one-third part, blackish tibiae, and about 20-35 rhinaria on antennal segment III has been found on Heterotheca grandiflora (Santa Paula,
Ventura County, California, July 5, 1961, leg. Schlinger and Hall [van den Bosch, no. 61-7-6b]), and Aster sp. (Leavenworth, Washington, July 1, 1960, leg. Schlinger and van den Bosch, no. 60-7-28s). This form has been identified with D. katonkae (Hottes) from Aster leaves; however, it differs by having longer tarsi, a conspicuously thin cauda, pale siphunculi and tibiae, and fewer rhinaria in apterae. Material of this aphid from Baccharis pilularis was examined, and I believe that this is $\mathrm{Nec}$ tarophora baccharidis Clarke, 1903, which I consider to be a subspecies of erigeronensis Thomas.

A third form, resembling typical erigeronensis, with the hind tibiae black in oviparae, but which has a last rostral segment with a total of about 16-22 hairs, is known only as oviparae from Haplopappus acradenius (Garnet, Riverside County, California, January 16, 1964, H.R.L., no. 137).

Fairly normal erigeronensis were collected from Gutierrezia bracteata (syn. californica) (Antioch, Contra Costa County, California, March 12, 1964, H.R.L., no. 162).

\section{Dactynotus russellae Hille Ris Lambers, 1960}

Originally described from eastern Canada, where it infests Anaphalis margaritacea, but in California we found it near Carmel Valley (Monterey County) on Gnaphalium beneolens and G. californicum, and in the dunes south of San Francisco on G. bicolor. (See also, notes under Masonaphis richardsi, p. 592.)

\section{Drepanosiphum zimmermanni Börner, 1940}

It is well known that the European Drepanosiphum platanoidis (Schrank, 1801), is widely spread in the United States. However, it appears that a second European Drepanosiphum is established in California. Alate females of this species have an orange-brown thorax and a pale green abdomen, with a pitch-black spot just below the siphunculi. Males have a black head and tho- rax and black bars on the abdomen. Oviparae are olive, with dark bars. Larvae are very pale green. The species can be easily recognized because a short basal part of antennal segment III tends to be darker than the part more distad. In Europe it infests Acer monspessulanum and $A$. opalus, but at Berkeley large numbers were found on $A$. macrophyllum.

\section{Epameibaphis atricornis Gillette and Palmer, 1933}

In southern California this aphid is common on California sagebrush (Arte-

misia californica) and basin sagebrush (A. tridentata). 


\section{Eriosoma pyricola Baker and Davidson, 1917}

For many years, the pear-root Eriosoma in California has been called $E$. lanuginosum Hartig, based on the assumption that the western and central European form that alternates between elm and pear roots was involved. However, de Fluiter (1933, pp. 65 and 66) has given a number of very important differences between the exules of $E$. lanuginosum and those of the Californian $\boldsymbol{E}$. pyricola Baker and Davidson.
These differences, viz., a shorter last rostral segment and more caudal hairs in pyricola than in exules of lanuginosum, hold for all the material I received from California and Oregon, and that I collected in California.

From the type of Ulmus galls in California, it would seem that Eriosoma inopinatum Alfieri, 1920, which occurs in southern Europe, is a synonym of $E$. pyricola.

\section{Eutboracaphis umbellulariae (Essig, 1932)}

Thoracaphis umbellulariae Essig, described from Umbellularia californica, on which it is very common, often making the trees look sooty black, also infests Cinnamomum camphora in California. Takahashi erected the subgenus (of Nipponaphis Pergande) Euthoracaphis Takahashi, 1938, for umbellulariae Essig, and in 1959 he considered it a full genus, stating that Thoracaphis cinnamoniae Shinji, 1941, was a synonym of the genotype. In comparing Japanese material of cinnamoniae in the Essig collection and in mine with types and other material of California umbellulariae, I found that the number of dorsal hairs in all California apterae is about twice that in Japanese apterae. Therefore cinnamoniae Shinji, although congeneric with umbellulariae Essig, can be considered a separate species.

Although Euthoracaphis umbellulariae (Essig) is a member of a typically eastern Asiatic group of aphids, there is as yet no indication as to whether it was introduced or is native to California.

\section{Fimbriaphis gentneri (Mason, 1947)}

This species was originally described from Oregon as a Macrosiphum from pear, Pyrus communis, but as this tree has no such aphid in Europe or Asia, it was suspected to have other host plants. Various planted species of $\mathrm{Cra}$ taegus (hawthorn) in the San Francisco Bay area were heavily infested with this aphid, which produced sexuals and eggs in the autumn.

\section{Gharesia polunini Stroyan, 1963}

This aphid was quite recently described from Carex or Kobresia at 12,750 feet in the Himalayas of West Pakistan. It has also been found in California, presumably on a composite, i.e., White Mountains, 12,500 feet, leg. E. Schlinger, July 15, 1961 (R. van den
Bosch, no. 61-7-15d). The Califormia material contained alatoid nymphs which were not old enough to enable detection of any character of the unknown alatae by looking through their skin. The California material differs in no way from the type material.

\section{Glabromyzus schlingeri $\mathrm{n}$. sp.}

\section{Apterous viviparous female}

In life. Color not known, probably rather dark.

In mounted specimens. Body about
1.40-1.65 mm long. Tergum brown to dark brown, sclerotic, with a solid, sometimes transversely banded, occasionally perforated, wrinkled and variolous shield that includes metanotum 
TABLE 8

SAMPLE MEASUREMENTS OF GLABROMYZUS SCHLINGERI n. sp. (Apterous Viviparous Females)

\begin{tabular}{|c|c|c|c|c|c|c|c|c|}
\hline \multirow{3}{*}{$\begin{array}{c}\text { Specimen } \\
\text { number }\end{array}$} & \multicolumn{7}{|c|}{ Sample measurements in $\mathrm{mm}$} & \multirow{3}{*}{ Cauda } \\
\hline & \multirow{2}{*}{$\begin{array}{c}\text { Body } \\
\text { length }\end{array}$} & \multirow{2}{*}{ Antennae } & \multicolumn{4}{|c|}{ Antennal segments } & \multirow{2}{*}{$\underset{\text { culi }}{\text { Siphun- }}$} & \\
\hline & & & III & IV & $\mathrm{V}$ & VI & & \\
\hline $1^{*}$. & 1.62 & 0.97 & 0.25 & 0.14 & 0.14 & $0.10+0.23$ & 0.32 & 0.14 \\
\hline $2 \ldots$ & 1.43 & 0.93 & 0.20 & 0.14 & 0.13 & $0.10+0.25$ & 0.32 & 0.13 \\
\hline
\end{tabular}

* Specimen no. 1 is the holotype.

and abdominal tergite VII; pronotum and mesonotum with mutually free, dark-sclerotic bars, but abdominal tergite VIII lacks a sclerite. Dorsal hairs on abdominal tergite III very short, about $0.005 \mathrm{~mm}$, with slightly incrassate apices, the 2 hairs on tergite VIII about 3 times that length. No marginal or spinal tubercles present. Head brown. Frontal tubercles very little developed, the convex median part of the front hardly lower than the slightly scabrous frontal tubercles. Antennae .57-.67 of length of body, quite pale in contrast to the head, with segment $V$ from about halfway, and segment VI quite dark; flagellum completely imbricated, and segments I and II imbricated on the underside; segment III without rhinaria; hairs on segment III about onefourth of basal diameter of the segment. Rostrum short, reaching the middle coxae; last segment short, $0.09 \mathrm{~mm}$ long, about nine-tenths of second joint of hind tarsi, with 2 hairs besides the 3 subapical pairs. Legs pale, with the apices of the tibiae dusky and the tarsi dark brown; femora rather sharply imbricated on underside and distal half; tibiae smooth, with short, blunt hairs on basal part that gradually change apicad to longer, stiff, spiny hairs; first tarsal joints with $3,3,3$ hairs, the middle hairs very little shorter than the lateral ones; empodial hairs as long as claws. Siphunculi pale, with apical .17-.20 part as dark as the tarsi, about .20-.22 of length of body; on distal half, especially on the inner side, swollen, rapidly tapering from a funnel-shaped base to a gradually tapering stem which in dorsal view at the thinnest spot is about 1.67 times the diameter of mid-portion of the hind tibiae, in lateral view 1.40 times that diameter, at the thickest place on distal half 1.87-2.00 times that diameter; surface wrinkled on basal half, dispersely imbricated on distal half dorsally, with some indistinct spinules ventrally; flange thin and rather small, about as wide as the mid-portion of hind tibiae, or just less. Cauda pale, more or less triangular, with slightly convex sides, blunt, two-fifths of siphunculi, with 5 hairs. (See table 8.)

\section{Alate viviparous female (from one specimen)}

In life. Color not known.

In mounted specimen. Head and thorax blackish, the abdomen very strongly resembling that of Myzus (Nectarosiphon) persicae and relatives; with marginal sclerites; with, on tergites I and II, transverse scattered sclerites that on tergite II tend to coalesce to a thin, transverse bar; with a large, dark, central sclerite extending from the spinal hairs of tergite III, to and including the spinal hairs of tergite VI, with some perforations between tergites V and VI and a link only to the pleural intersegmental sclerites between tergites III and IV, not to those between IV and V; striate ventral sclerites on segments III-VI present, but not very dark. 


\section{TABLE 9}

SAMPLE MEASUREMENTS OF

GLABROMYZUS SCHLINGERI n. sp.

(Alate Viviparous Female-Single Specimen)

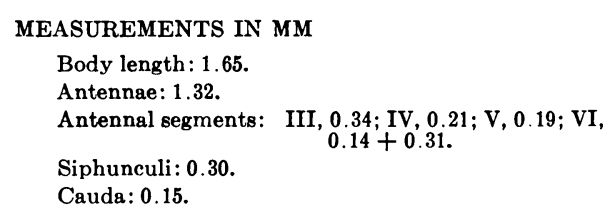

Number of rhinaria on antennal segments III: 8 and 9.

Antennae dark (base of segment III paler), four-fifths of length of body; segment III with 8-9 rather large, slightly elevated rhinaria in a row over three-fourths of the segment. Wings with normal venation, the veins and the stigma grayish brown; hind wings with both obliques present. Legs with most of the femora dark, with basal .11-.25 pale; tibiae pale, with apical .20-.25 dark like the tarsi. Siphunculi evenly dark, suddenly narrowing from a wide base to a stem which at its thinnest part is 1.50-1.60 times as wide as the midportion of the hind tibiae, from there rapidly expanding to a width of 2.20 times the mentioned tibial width, and then more gradually tapering to the thin flange; surface dorsally on basal two-thirds part with rather disperse nodules, smooth apicad just before the flange, with a few transverse striae in an indistinct annular incision. Cauda slender, with concave sides, blunt, darker at base than at apex. (See table 9.)

\section{Larvae}

Alatoid nymph with dark wing pads; no pigment in integumentum of body; siphunculi smoky, with dark apex. No spinules on outer side near apex of hind tibiae.

Notes. The slide holding the above aphids was received, labeled $R$ hopalosiphum rhois Monell, collected from Rhus "toxodendron," Orinda, Contra Costa County, California, September 29, 1961, leg. E. Schlinger (R. van den Bosch, no. 61-9-30c). Since the host plant, Rhus toxicodendron (poison ivy), according to Munz (1963), is not native to California and not likely to be cultivated, I assume that $R$. diversiloba (poison oak) was involved.

Apparently, several taxa pass as rhois Monell in collections and papers. Monell (see Riley and Monell, 1879) described his Rhopalosiphum rhois from an undetermined species of sumac, which would mean a member of the subgenus Sumac De Candolle (Rhus typhina or $R$. glabra). In material from either of these hosts in my collection the processus terminalis in alatae is about $3.00-3.50$ times as long as the base of segment VI, 1.00-1.15 times as long as segment V plus the basal part of VI, which agrees with Monell's statement that the alata has the "seventh joint a little longer than the two preceding taken together." This sumac-infesting aphid has been supposed to migrate to grasses, and therefore Amphorophora howardii Wilson, 1911, described from Panicularia nervata (syn. Glyceria striata), was considered to be a synonym (e.g., Palmer, 1952). In view of the absence of published results of transfer tests, Richards (1960) doubts this synonymy. The species breeds throughout the summer on Rhus typhina, which of course does not exclude host alternation, as specimens from Elymus canadensis demonstrate. A taxon on poison ivy (subg. Toxicodendron, e.g., Rhus radicans) in the eastern states is rather different in the length of its processus terminalis in alatae, which is about 4.50-5.50 times as long as the base of segment VI, and 1.40-1.70 times as long as segment $V$ plus the basal part of VI. Its second generation is almost completely alate, and I know of no records of the species from poison ivy in midsummer. Wilson (1911), in his description of Amphorophora howardii, gives measurements that show the processus terminalis in alatae to be 4.67 times as long as the 
base of segment VI and 1.43 times as long as segment $\mathrm{V}$ plus basal part of VI, which agrees with the measurements of the poison ivy specimens, but not with those from sumac. Provisionally, the name Glabromyzus howardii (Wilson, 1911) could be applied to this poison ivy aphid. (See also, comment on $\mathrm{p}$. 620).

Glabromyzus schlingeri $\mathrm{n}$. sp. differs from either of the above species in that its alatae have a central sclerite on the abdomen and a very much shorter processus terminalis, and in that the apterae have pale antennae, pale tibiae, and a sclerotic dorsum.

Type material. Holotype: Apterous viviparous female from Rhus "toxodendron" (probably $R$. diversiloba), Orinda, Contra Costa County, California, September 29, 1961, leg. E. Schlinger (R. van den Bosch, no. 619-30c). Paratypes: One aptera and one alata, with data as for holotype.

\section{Macrosiphoniella cinerescens $\mathbf{n}$. sp.}

\section{Apterous viviparous female}

In life. Basically bright sea-green, with paired, narrow oval, white-green spots of wax powder which leave a zigzag median line and marginal spots bare; ventrally grayish white. Siphunculi on distal half dark, but not black; on basal pale greenish. Cauda pale greenish, with dusky apex.

In mounted specimens. Body elongated, about 2.10-2.60 mm long, unpigmented. Dorsal hairs stiff, the longest on abdominal tergite III about 1.67 times the basal diameter of antennal segment III; about 12-16 on each of abdominal segments II-IV, 4-6 on tergite VIII, all with spear-shaped apices. No marginal tubercles present on abdomen. Frontal tubercles very well developed, smooth, strongly diverging; frontal furrow deeply concave. Antennae much longer than body, the basal segments faintly brownish, with segment III pale at base, gradually darker toward apex, and the rest abruptly darker to blackish; segment III on basal .25-.33 part on one side with about 10-13 scattered, hardly tuberculate, small to extremely small rhinaria, the membranes of which protrude like flattened to almost complete globes; interrelations of segment see measurements; longest hair on segment III just longer than basal diameter of segment. Rostrum reaching to or just past hind coxae; last segment almost exactly as long as the long second joint of hind tarsi, with straight to just concave sides, with the longest hairs on basal half, in total with about 8 hairs besides the 3 subapical pairs. Legs long, pale, with the femora before apex brown to fuscous dorsally, the tibiae fuscous at base, black at apex, pale to mottled fuscous in the intervening areas; first tarsal joints with 3 spiny hairs, of which the lateral ones are twice as long as the middle ones. Siphunculi rather tapering from base to just before apex, where the minimum width is just under the width of the mid-portion of hind tibiae, $.20-.25$ of length of body, pale at base and gradually darker to blackish toward apex, with smooth base and slightly imbricated second fourth, reticulated over distal .33-.40 part, with small flange. Cauda pale, but darker than the subgenital plate, almost cylindrical on basal half, gradually tapering, with faintly convex sides, to the rather acute apex, shorter than siphunculi, with some 14-18 hairs. (See table 10.)

\section{Alate viviparous female}

In life. Much like apterae, but with less wax powder; thorax not brown but green.

In mounted specimens. Body very much as in apterae, but head slightly brownish frontally and around the ocelli, and thorax slightly smoky. Antennae a little longer, blackish, with only base of segment III pale, and segments I and II mottled fuscous; segment III over nearly its whole length 
TABLE 10

SAMPLE MEASUREMENTS OF MACROSIPHONIELLA CINERESCENS n. sp. (Apterous Viviparous Females)

\begin{tabular}{|c|c|c|c|c|c|c|c|c|c|}
\hline \multirow{3}{*}{$\begin{array}{l}\text { Specimen } \\
\text { number }\end{array}$} & \multicolumn{8}{|c|}{ Sample measurements in $\mathrm{mm}$} & \multirow{3}{*}{$\begin{array}{l}\text { Rhinaria on } \\
\text { antennal } \\
\text { segments III }\end{array}$} \\
\hline & \multirow{2}{*}{$\begin{array}{l}\text { Body } \\
\text { length }\end{array}$} & \multirow{2}{*}{$\begin{array}{c}\text { Anten- } \\
\text { nae }\end{array}$} & \multicolumn{4}{|c|}{ Antennal segments } & \multirow{2}{*}{$\begin{array}{l}\text { Siphun- } \\
\text { culi }\end{array}$} & \multirow{2}{*}{ Cauda } & \\
\hline & & & III & IV & V & VI & & & \\
\hline $1 * \ldots \ldots \ldots$ & 2.16 & 3.56 & 0.91 & 0.66 & 0.59 & $0.23+0.94$ & 0.62 & 0.48 & 10 and 13 \\
\hline $3 \ldots \ldots$ & 2.55 & 3.56 & 0.91 & 0.68 & 0.62 & $0.22+0.87$ & 0.60 & 0.44 & 11 and 13 \\
\hline $4 \ldots \ldots$ & 2.46 & 3.34 & 0.87 & 0.61 & 0.57 & $0.21+0.83$ & 0.59 & 0.44 & 10 and 11 \\
\hline
\end{tabular}

* Specimen no. 1 is the holotype.

along one side with some $35-45$ rhinaria like those in apterae. Legs with blackish brown apices to the femora and with most of the tibiae quite darkly mottled. Wings with rather dark brown normal venation. Siphunculi with more contrasting pale base, and less tapering than in apterae. Cauda very little thinner than in apterae. (See table 11.)

Notes. This decorative aphid infests the lower leaves of Achillea californica, turning their tips brown. A small colony was found near the road from Stinson Beach to Muir Woods, Marin County, California, but not in dozens of similar localities where the host plant grew. The plants were growing on a southwest slope.

The species is morphologically most nearly related to Macrosiphum pennsylvanicum Pepper, 1950, which I place in Macrosiphoniella del Guercio. But in pennsylvanicum, paratypes of which are available, the rhinaria protrude even more, their membranes are almost pedunculate, and in the apterae there are 31-44, covering .67-.86 of the length of the segment; the whole insect has darker extremities, so that the siphunculi have only the very base pale; the femora are dark brownish, with pale bases and black apices; the tibiae are quite black in apterae; and the dorsal hairs on abdominal segment III are up to twice the basal diameter of antennal segment III. This was the only Macrosiphoniella we found on Achillea in California, since M. millefolii (de Geer) and $M$. tapuskae (Hottes and Frison) could not be found.

Type material. Holotype: Apterous viviparous female (specimen no. 1 of measurements) from Achillea californica, between Stinson Beach and Muir Woods, Marin County, California, March 8, 1964, leg. H.R.L., no. 160. Paratypes: Apterae and alatae with data as for holotype.

TABLE 11

SAMPLE MEASUREMENTS OF MACROSIPHONIELLA CINERESCENS n. sp. (Alate Viviparous Females)

\begin{tabular}{|c|c|c|c|c|c|c|c|c|c|}
\hline \multirow{3}{*}{$\begin{array}{c}\text { Specimen } \\
\text { number }\end{array}$} & \multicolumn{8}{|c|}{ Sample measurements in $\mathrm{mm}$} & \multirow{3}{*}{$\begin{array}{l}\text { Rhinaria on } \\
\text { antennal } \\
\text { segments III }\end{array}$} \\
\hline & \multirow{2}{*}{$\begin{array}{c}\text { Body } \\
\text { length }\end{array}$} & \multirow{2}{*}{$\underset{\text { nae }}{\text { Anten- }}$} & \multicolumn{4}{|c|}{ Antennal segments } & \multirow{2}{*}{$\underset{\text { culi }}{\text { Siphun- }}$} & \multirow{2}{*}{ Cauda } & \\
\hline & & & III & IV & $\mathrm{v}$ & VI & & & \\
\hline 1. & 2.62 & 3.70 & 0.92 & 0.69 & 0.64 & $0.25+0.98$ & 0.50 & 0.40 & 42 and 44 \\
\hline $2 . \ldots$. & 2.81 & 3.79 & 0.95 & 0.73 & 0.64 & $0.23+1.00$ & 0.52 & 0.43 & 37 and 39 \\
\hline
\end{tabular}




\section{Macrosiphum raysmithi $\mathrm{n}$. sp.}

\section{Apterous viviparous female}

In life. Very pale green to whitish green, with the margin just visibly greener, without a median line, not shiny. All appendages colorless, but segments of flagellum with extreme apices dark.

In mounted specimens. Body quite elongate, $3.10-3.70 \mathrm{~mm}$ long. Dorsal hairs stiff, blunt, short, the longest on abdominal segment III is .50-.60 of basal diameter of antennal segment III, but the 6-8 hairs on tergite VIII just longer than that diameter and with a very wide gap between the middle pair. Very small tubercles of about the width of a hair socket but as high as wide, hardly visible, but usually marginally present on tergites II-VI and often spinally on tergite VIII, where they are easily mistaken for sockets of broken hairs. Frontal tubercles smooth, moderately developed, strongly diverging, with only 1-2 hairs on inner side and 1 on the underside; frontal furrow rather wide, with convex bottom because a low median tubercle is present. Antennae longer than body, pale, with the very apices of segments III, IV, and V, the very bases of IV and $V$, and the whole segment VI dark to blackish; fla- gellum up to basal .25-.50 of segment IV smooth, from there on gradually more distinctly imbricated; segment III near base with $1-4$, rarely 0 , very small, quite flat, very inconspicuous rhinaria in a row; longest hair on segment III about half as long as basal diameter of the segment. Rostrum short, just reaching to the middle coxae; apical segment blunt and very short, 0.11$0.12 \mathrm{~mm}$, as long as antennal segment II, about seven-tenths of second joint of hind tarsi, with usually 6 hairs besides the 3 subapical pairs. Legs long, pale, with brown tarsi; first tarsal joints with 3 hairs; second joints imbricated; empodial hairs often longer than the small claws. Siphunculi pallid, twosevenths or a little more of length of body, tapering on basal .29-.33 part, the rest cylindrical, with the reticulated area slightly constricted, faintly imbricated from base, reticulated on distal .17-.20 part, in the middle about 1.10 times as wide as the mid-portion of the hind tibiae, with a small flange. Cauda pallid, rather thick, gradually tapering from base to the rounded apex, about half as long as siphunculi, with laterally 12-15 hairs and with only one hair dorso-apically. (See table 12.)

TABLE 12

SAMPLE MEASUREMENTS OF MACROSIPHUM RAYSMITHI n. sp.

(Apterous Viviparous Females)

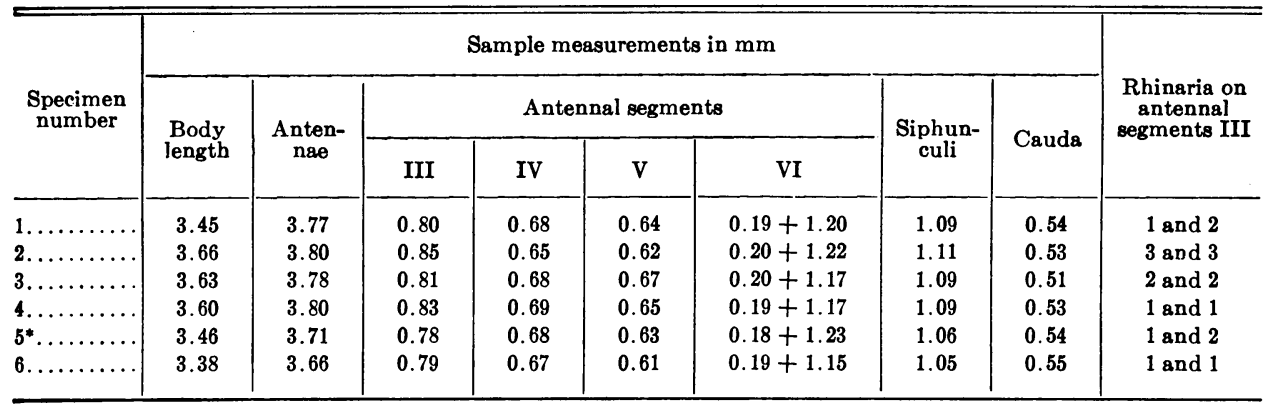

- Specimen no. 5 is the holotype. 
TABLE 13

SAMPLE MEASUREMENTS OF MACROSIPHUM RAYSMITHI n. sp. (Alate Viviparous Females)

\begin{tabular}{|c|c|c|c|c|c|c|c|c|c|}
\hline \multirow{3}{*}{$\begin{array}{l}\text { Specimen } \\
\text { number }\end{array}$} & \multicolumn{8}{|c|}{ Sample measurements in $\mathrm{mm}$} & \multirow{3}{*}{$\begin{array}{l}\text { Rhinaria on } \\
\text { antennal } \\
\text { segments III }\end{array}$} \\
\hline & \multirow{2}{*}{$\begin{array}{c}\text { Body } \\
\text { length }\end{array}$} & \multirow{2}{*}{$\begin{array}{c}\text { Anten- } \\
\text { nae }\end{array}$} & \multicolumn{4}{|c|}{ Antennal segments } & \multirow{2}{*}{$\begin{array}{l}\text { Siphun- } \\
\text { culi }\end{array}$} & \multirow{2}{*}{ Cauda } & \\
\hline & & & III & IV & $\mathbf{V}$ & VI & & & \\
\hline $1 \ldots \ldots \ldots \ldots$ & 3.28 & 3.86 & 0.79 & 0.72 & 0.66 & $0.20+1.25$ & 0.87 & 0.40 & 9 and 10 \\
\hline $2 \ldots \ldots \ldots$ & 3.19 & 3.79 & 0.75 & 0.70 & 0.67 & $0.20+1.23$ & 0.86 & 0.40 & $?$ and 8 \\
\hline
\end{tabular}

\section{Alate viviparous female}

In life. Much like apterae, but thorax very faintly orange, otherwise appearing teneral.

In mounted specimens. Thorax very faintly brownish yellow, a striking blackish brown ring around two-thirds of each lateral ocellus on the otherwise pale head, the rest of the body quite unpigmented. Antennae with inner side of segment I fuscous, the rest pale brownish yellow, with dark parts as in apterae; segment III on basal .57-.75 part with a row of some 8-10 rhinaria, which are larger and much more conspicuous than in apterae. Tibiae brownish at apex. Venation of wings normal, with veins a washed-out brown. Siphunculi more cylindrical and shorter than in apterae, in the middle just darker than near base and apex. Cauda much thinner and more cylindrical than in apterae. (See table 13.)

Notes. Large, very compact colonies of this aphid were found on the undersides of the leaves of about one-half of a bush of Lonicera involucrata var. ledebouri growing on the northern slope of Strawberry Canyon, Berkeley, Alameda County, California. This type of colony is very unusual for a Macrosiphum; the insects sat adpressed to the leaves, in dense groups, closely surrounded by their larvae which, like the mothers, were much paler than the pale undersides of the leaves of the host plant.
Also, the adults did not, as do most members of the genus, drop on disturbance. Infested leaves showed no effects. The many other bushes in the same area were free of aphids. Notwithstanding the high population density, alatoid nymphs or alatae were quite rare, as only two alatoid nymphs were found and bred to adulthood among thousands of adult apterae.

The species can be very easily recognized by the extremely small rhinaria of apterae, and by the very short rostrum and last rostral segment. Macrosiphum oredonense Remaudière, 1952, from the European Lonicera nigra, is very closely related, as comparisons with a paratype and with specimens from Switzerland and Czechoslovakia show, but it differs in having dark apices to the tibiae, shorter empodial hairs, much larger marginal tubercles, basal portion of antennal segment VI nearly twice as long, and more and larger rhinaria in apterae viviparae. In most other characters there is a striking similarity, and apparently the species vicariate.

Type material. Holotype: Apterous viviparous female (specimen no. 5 of measurements) from Lonicera involucrata var. ledebouri, Strawberry Canyon, Berkeley, Alameda County, California, March 29, 1964, leg. H.R.L., no. 197. Paratypes: Alatae and many apterae with the data of the holotype, leg. H.R.L., nos. 194 and 197. 


\section{Masonaphis ceanothi (Bartholomew, 1932)}

MacGillivray (1958) does not discuss this aphid in her monograph of the genus Masonaphis Hille Ris Lambers, for nothing in the description by Bartholomew (1932) of the apterous viviparous female suggests a relationship to Masonaphis. However, if alatae had been found first, the species would have been referred to Masonaphis Hille Ris Lambers without hesitation, for alatae show 2-6 rows of hexagonal cells at the apex of the siphunculi. The sensoriation of antennal segment III (0-3 rhinaria in apterae, 5-9 on basal half in alatae), the last rostral segment $(0.11 \mathrm{~mm}$, twothirds of the length of second joint of hind tarsi, with 5-8 hairs besides the 3 subapical pairs), the cauda with 6-8 hairs, and the very short hairs on body and antennae on segment III, up to half the basal diameter of the segment, also suggest that the species could better be placed in Masonaphis than in Amphorophora Buckton. The heavy venation of the wings, with a dark brown border along the pale stigma, is typical.

\section{Masonaphis lambersi MacGillivray, 1960}

It appears that this species, and not Masonaphis azaleae (Mason, 1925), is common on Rhododendron molle and cultivated Japanese Azalea in California. Two color forms are about equally common, a pink one and a green one.
Hibernation as eggs occurs, since oviparae were collected at Pebble Beach, Monterey County, California, August 22, 1963, and a fundatrix at Berkeley, Alameda County, California, March 17, 1964.

\section{Masonaphis macgillivrayae $\mathrm{n}$. sp.}

\section{Apterous viviparous female}

In life. Light yellowish green.

In mounted specimens. Body slender, about $2.60-3.15 \mathrm{~mm}$ long, with very faintly corrugated and thickened tergum. Dorsal hairs very short and inconspicuous, inverted bottle-shaped, the longest on abdominal tergite III only one-fourth of basal diameter of antennal segment III, but the 5-8 hairs on tergite VIII are .67-.75 of that diameter. Marginal tubercles mostly present only on abdominal segment $\mathrm{V}$, small, semiglobular; spinal tubercles larger and flatter, more often present on tergite VIII, sometimes on vertex. Frontal tubercles rather well developed, diverging, slightly imbricated on inner and underside, with 2-3 hairs, one of which is often much longer than the others, on inner side, and 1-3 on underside. Frontal furrow wide, with convex bottom or with a distinct, small, median tubercle. Antennae 1.10-1.25 times the length of body; flagellum gradually darker from the pale base to the blackish apex, with the extreme apices of segments III and IV blackish, clearly imbricated from base; segment III with 1-2 rather flat rhinaria on a slightly thickened part near base; if two rhinaria are present, they are mostly very close to each other; hairs on segment III like those on dorsum of the abdomen or even shorter. Rostrum reaching to halfway between the second and third pair of coxae; last segment $0.15-0.17$, mostly $0.16 \mathrm{~mm}$ long, 1.10-1.25 times the second joint of hind tarsi, pale, with dark apex, with 6-9 hairs besides the 3 subapical pairs. Legs long, yellowish, with dark apices to the tibiae, the latter with very short, thick hairs on the outer side on basal half; first tarsal joints of all legs with 5 hairs; second joints without spinules on the imbrications. Siphunculi about two-sevenths of length of body, 
TABIE 14

SAMPLE MEASUREMENTS OF MASONAPHIS MACGILLIVRAYAEn. sp. (Apterous Viviparous Females)

\begin{tabular}{|c|c|c|c|c|c|c|c|c|c|}
\hline \multirow{3}{*}{$\begin{array}{l}\text { Specimen } \\
\text { number }\end{array}$} & \multicolumn{8}{|c|}{ Sample measurements in $\mathrm{mm}$} & \multirow{3}{*}{$\begin{array}{c}\text { Rhinaria on } \\
\text { antennal } \\
\text { segments III }\end{array}$} \\
\hline & \multirow{2}{*}{$\begin{array}{l}\text { Body } \\
\text { length }\end{array}$} & \multirow{2}{*}{$\begin{array}{l}\text { Anten- } \\
\text { nae }\end{array}$} & \multicolumn{4}{|c|}{ Antennal segments } & \multirow{2}{*}{$\begin{array}{l}\text { Siphun- } \\
\text { culi }\end{array}$} & \multirow{2}{*}{ Cauda } & \\
\hline & & & III & IV & $\mathbf{V}$ & VI & & & \\
\hline 3.... & 2.94 & 3.49 & 0.79 & 0.66 & 0.59 & $0.17+1.06$ & 0.86 & 0.35 & 1 and 2 \\
\hline $4 \ldots$ & 2.64 & 3.38 & 0.71 & 0.61 & 0.57 & $0.15+1.11$ & 0.81 & 0.34 & 1 and 2 \\
\hline $5 * \ldots$ & 2.60 & 3.15 & 0.67 & 0.54 & 0.51 & $0.17+1.04$ & 0.79 & 0.31 & 1 and 2 \\
\hline $6 \ldots \ldots \ldots$ & 3.06 & 3.64 & 0.87 & 0.67 & 0.51 & $0.18+1.17$ & 0.93 & 0.38 & 2 and 2 \\
\hline
\end{tabular}

- Specimen no. 5 is the holotype.

pale, with extreme apices somewhat dark, from a slightly tapering base nearly cylindrical to past the middle, then widening to a maximum at distal one-fourth part, where they are about 1.25-1.35 times as wide as the smallest diameter toward base, or 1.60-1.70 times as wide as mid-portion of the hind tibiae, finally abruptly narrowing to the reticulated area, which is about as wide as the mid-portion of the hind tibiae; surface evenly but inconspicuously imbricated to the reticulated area, which covers .08-.11 of their length. Cauda pale, normal, tapering from base to half its length, from there slightly less tapering to the bluntish apex, two-fifths of length of siphunculi, with 7 hairs. (See table 14.)

Notes. Small colonies were found on the young leaves of Raphiolepis indica planted between the buildings of Deutsch Hall (residential), on Durant Avenue, Berkeley, Alameda County, California. Alatae or alatoid nymphs were not found. As the plant on which the aphids bred is a native of eastern Asia, and only one, very different, $M a$ - sonaphis is known to be native outside of North America, there probably is another rosaceous Nearctic host plant.

This aphid belongs to the subgenus Ericobium MacGillivray, 1958; MacGillivray gave a key to the then known species. With this key one arrives at couplet no. 43(44), M. (Ericobium) corylinum (Davidson) from Physocarpus, but in that species the hind tarsi are much shorter and the last rostral segment has 20 or more hairs against 15 at most in our species. Specimens with a shorter last rostral segment key to $M$. (Ericobium) wahnaga (Hottes) (from Smilacina), which has a different distribution of rhinaria, longer hairs on antennal segment III, and a shorter last rostral segment. These differences are of sufficient importance to warrant describing this species as new.

Type material. Holotype: Apterous viviparous female (specimen no. 5 of measurements) from Raphiolepis indica, Berkeley, Alameda County, California, March 27, 1964, leg. H.R.L., no. 182. Paratypes: Apterae with data as for holotype.

\section{Masonaphis richardsi MacGillivray, 1958, s. $l$.}

This little-known species was described from Anaphalis margaritacea from eastern Canada, and it is surprising that the next find should come from the dunes south of San Francisco, Cali- fornia, where it lived together with $D a c$ tynotus russellae Hille Ris Lambers in the inflorescences of Gnaphalium $b i$ color. (See also, notes on p. 583.) The San Francisco material differs very 
TABLE 15

SAMPLE MEASUREMENTS OF MASONAPHIS RICHARDSI subsp. PACIFICA n. subsp. (Apterous Viviparous Females)

\begin{tabular}{|c|c|c|c|c|c|c|c|c|c|}
\hline \multirow{3}{*}{$\begin{array}{l}\text { Specimen } \\
\text { number }\end{array}$} & \multicolumn{8}{|c|}{ Sample measurements in $\mathrm{mm}$} & \multirow{3}{*}{$\begin{array}{l}\text { Rhinaria on } \\
\text { antennal } \\
\text { segments III }\end{array}$} \\
\hline & \multirow{2}{*}{$\underset{\text { length }}{\text { Body }}$} & \multirow{2}{*}{$\begin{array}{c}\text { Anten- } \\
\text { nae }\end{array}$} & \multicolumn{4}{|c|}{ Antennal segments } & \multirow{2}{*}{$\begin{array}{l}\text { Siphun- } \\
\text { culi }\end{array}$} & \multirow{2}{*}{ Cauda } & \\
\hline & & & III & IV & $\mathbf{V}$ & VI & & & \\
\hline $3 \ldots$ & 2.80 & 3.48 & 0.79 & 0.54 & 0.56 & $0.19+1.13$ & 0.81 & 0.32 & 5 and 6 \\
\hline & 2.80 & 3.40 & 0.87 & 0.53 & 0.53 & $0.18+1.06$ & 0.81 & 0.33 & 6 and 6 \\
\hline $5 \ldots$ & 2.77 & 3.52 & 0.86 & 0.55 & 0.55 & $0.19+1.14$ & 0.78 & 0.30 & 3 and 6 \\
\hline $6 \ldots \ldots \ldots$ & 2.53 & 3.50 & 0.89 & 0.53 & 0.53 & $0.20+1.09$ & 0.77 & 0.32 & 7 and 8 \\
\hline
\end{tabular}

* Specimen no. 4 is the holotype.

little from the types. The siphunculi are just thinner, the antennal hairs and the second joints of the hind tarsi somewhat shorter, so that in the California insects the last rostral segment, although exactly the same shape and length as in the types, is up to twice as long as these tarsal joints.

However, a form taken in Strawberry Canyon, Berkeley, California, on the original host plant, Anaphalis margaritacea, as apterae looks so different that any systematist would be inclined to place it in Sitobion Mordvilko but for the last rostral segment, which is precisely as in the types of $\boldsymbol{M}$. richardsi. The alatae leave no doubt as to its generic position. These samples demonstrate clearly that the structure of the rostrum is of very great taxonomic importance, since it remains constant where other accepted characters vary widely.

It now appears advisable to describe the latter aphid as a subspecies, by enumerating the differences from the original description in MacGillivray (1958).

\section{Masonaphis richardsi subsp. pacifica $n$. subsp.}

\section{Apterous viviparous female}

Basal .33-.50 of antennal segment III with 3-9 rhinaria. Siphunculi on distal one-fourth not, or rarely more than, 1.20 times as thick as at thinnest place more basad, sometimes cylindrical to the middle and from there gradually tapering to apex; the thinnest part on basal half 1.33-1.50 times as thick as thickest part of the hind tibiae, i.e., hardly or not swollen because of a thick stem; apical reticulation consisting of 2-3 rows of strongly transverse cells covering only about a one-fortieth part of the length of the siphunculi; and the reticulated part nearly as pale as the rest of the siphunculi. Cauda with 7-10 hairs. Other characters are as in the main species. (See table 15.)

\section{Alate viviparous female}

Siphunculi on distal half swollen to 1.10-1.20 times smallest diameter more basad, and there about 1.10-1.20 times as thick as the hind tibiae. Other characters are as in the main species, but antennal segment III is mostly darker than segment IV. (See table 16.)

Type material. Holotype: Apterous viviparous female (specimen no. 4 of measurements) from Anaphalis margaritacea, Strawberry Canyon, Berkeley, Alameda County, California, January 1, 1964, leg. H.R.L., no. 111. Paratypes: Apterae and alatae with data as for holotype. 
TABLE 16

SAMPLE MEASUREMENTS OF MASONAPHIS RICHARDSI subsp. PACIFICA n. subsp. (Alate Viviparous Females)

\begin{tabular}{|c|c|c|c|c|c|c|c|c|c|}
\hline \multirow{3}{*}{$\begin{array}{l}\text { Specimen } \\
\text { number }\end{array}$} & \multicolumn{8}{|c|}{ Sample measurements in $\mathrm{mm}$} & \multirow{3}{*}{$\begin{array}{l}\text { Rhinaria on } \\
\text { antennal } \\
\text { segments III }\end{array}$} \\
\hline & \multirow{2}{*}{$\underset{\text { length }}{\text { Body }}$} & \multirow{2}{*}{$\begin{array}{c}\text { Anten- } \\
\text { nae }\end{array}$} & \multicolumn{4}{|c|}{ Antennal segments } & \multirow{2}{*}{$\begin{array}{l}\text { Siphun- } \\
\text { culi }\end{array}$} & \multirow{2}{*}{ Cauda } & \\
\hline & & & III & IV & $\mathrm{V}$ & VI & & & \\
\hline $3 \ldots \ldots \ldots \ldots$ & 2.68 & 3.70 & 0.93 & 0.59 & 0.59 & $0.21+1.17$ & 0.71 & 0.32 & 17 and 17 \\
\hline $4 \ldots \ldots$ & 2.86 & 3.67 & 0.91 & 0.59 & 0.57 & $0.21+1.17$ & 0.71 & 0.29 & 18 and 19 \\
\hline
\end{tabular}

\section{Myzocallis agrifolicola Richards, $1966^{4}$}

\section{Alate viviparous female (possibly fundatrix)}

In life. In two color forms, one with a blackish mottled abdomen, the other with a reddish brown abdomen, otherwise alike. With black head and thorax, colorless antennae and legs, and remarkably banded wings. (See fig. 1.)

In mounted specimens. Head and thorax black, with paler spots around the bases of the hairs on vertex and pronotum; abdomen with paired, transversely oval, raised, spinal sclerites, each with 2 hairs on a paler zone, often with a median sclerite between the preceding sclerites on the anterior abdominal segments; with normal black marginal sclerites on segments $I$ and $V$, but on II-IV, especially on the latter, very large marginal sclerites that actually are coalesced marginal plus pleural sclerites, each with 3 marginal hairs on a semiglobular processus and with 1 pleural, not much raised, hair; pleural sclerites of tergite $\mathrm{V}$ not fused with marginal sclerites, but each with an extension spinad; siphuncular sclerite

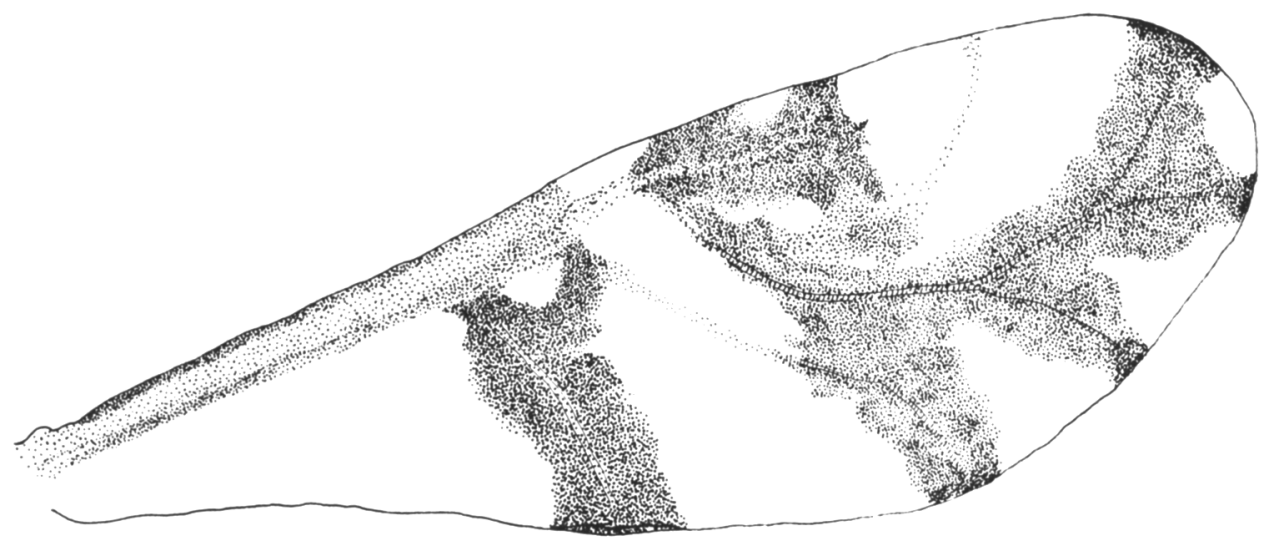

Fig. 1. Forewing of Myzocallis agrifolicola Richards.

'I had described this aphid as Myzocallis dicksoni n. sp., giving the description that follows this heading, continuing to the end of the first paragraph under the heading "Notes." However, while the present paper was still in the proof stage, the same aphid was described by W. R. Richards as Myzocallis agrifolicola in Canadian Ent. 98:879-80 (August, 1966). Because our descriptions are somewhat different, I am retaining my own and referring the reader to that of Richards for comparison. See the end of this section for further comments.-H.R.L. 
TABLE 17

SAMPLE MEASUREMENTS OF MYZOCALLIS AGRIFOLICOLA Richards, 1966 (Alate Viviparous Females)

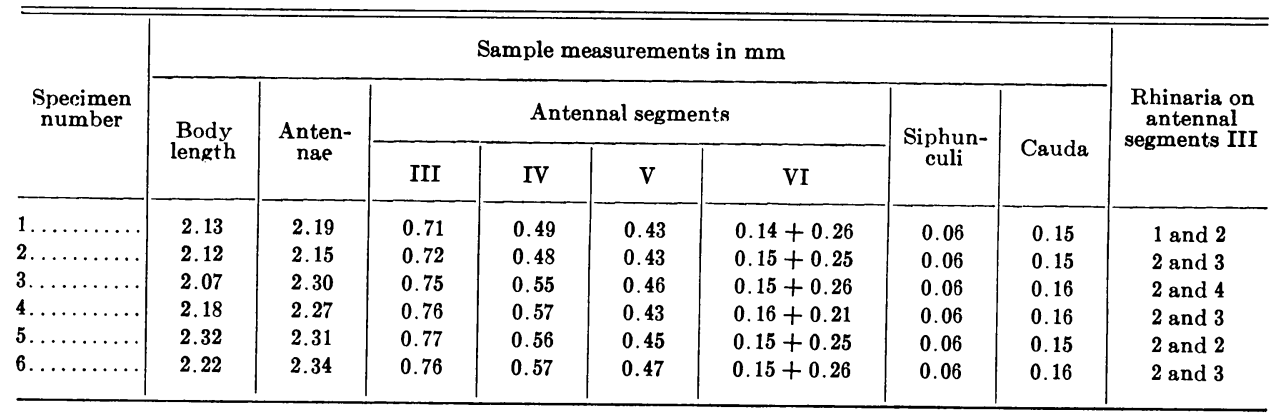

large, spinad with an extension, and caudad fused with marginal sclerite of tergite VI; tergite VIII with the sclerites at the bases of the 8-10 hairs sometimes partly coalescing; ventrally rows of small, very dark sclerites, especially on the posterior sternites. Dorsal hairs on medium-sized sockets, somewhat pigmented, stiff, with slightly capitate, pallid apices, the longest spinal ones on tergite III 2.00-2.20 times, those on VIII 3.00-3.60 times the basal diameter of antennal segment III. Integumentum smooth, but the marginal sclerites laterally scabrous, especially those of tergite II. Antennae longer than body, pale, with segment $I$ and the extreme base of segment II very dark, the apex of the flagellum faintly dusky; base of segment III with 1-4 roundish rhinaria, of which one is often much smaller than the others; these rhinaria with spinulose outer rim; primary rhinaria smaller than the secondary ones; hairs on segments I and II markedly curved, 1.502.00 times the basal diameter of segment III, but hairs on III straight and only .60-.70 of that diameter. Rostrum almost reaching the middle coxae; last segment bluntish, about $0.095 \mathrm{~mm}$ long, about four-fifths of second joints of hind tarsi, with $6-8$ hairs besides the 3 subapical pairs. Legs almost colorless, with dark, smoky tarsi; hairs on outer side and halfway the length of the hind tibiae sloping at $45^{\circ}$, slightly capitate, and up to 1.50 times as long as the local diameter of the tibiae; first tarsal joints with 6-7 ventral and 2 dorsal hairs. Wings with vague sector radii, with a quite constant pattern of pigmentation in blackish brown. Siphunculi quite black, cylindrical, with a wide base, smooth, without flange, hairless, the hairs caudad being the marginal hairs of tergite VI. Cauda colorless, constricted, with a thick, squarish knob bearing 4 quite long hairs, 3 shorter ones, and about 5-7 considerably shorter and thinner ones on the underside. Subanal plate not very deeply bilobed, colorless except dorsally at base, where it is brownish. Subgenital plate colorless. (See table 17.)

\section{Larvae}

First-instar larvae with spinal and marginal hairs in straight longitudinal rows, the hairs very stout, tapering to a rather thin but just blunt point, not capitate, and rather even in length, from $0.073 \mathrm{~mm}$ on tergite III to 0.087 mm on tergite VII. Distal .33-.40 part of the dorsal hairs on born larvae distinctly scabrous, with the very apex just enlarged, the hairs on blackish sclerotic basal plates. Last-instar larvae with duplicated spinal hairs, of which the inner pair is shorter, thinner, and on a small sclerite; with single pleural 
hairs of the length of the inner spinal pair; and with groups of 3 marginal hairs in 3 sizes; the sclerotic base plates of the latter tend to coalesce, but not (or hardly) those of the other hairs. Antennal hairs are as in adults.

Notes. I found this species on the undersides of the medium young leaves of Quercus agrifolia opposite the entrance to Giannini Hall on the University of California campus at Berkeley, but not on other species of oak, on the campus or elsewhere. However, this was not the first time I had seen this aphid, because Dr. F. W. Quednau had sent me a photograph of it as a Christmas greeting five years earlier. In recent correspondence, Dr. Quednau stated that he did not wish to describe this species, and he asked me to do so.

W. R. Richards expresses the belief that the species has been introduced, comparing it to kuricola Matsumura, 1917, from Japan. However, that species belongs to a totally different group, known as Nippocallis Matsumura, 1917, in which the forewings lack the radial sector, and in which the antennal hairs are very long, the body hairs more numerous.

\section{Myzus (Nectarosiphon) dianthicola n. sp.}

\section{Apterous viviparous female}

In life. Dark green to apple green, often with a lighter green median band down dorsum. Siphunculi often slightly darkened, much darker at the very apex. Cauda pale green.

In mounted specimens. Body rather broad, completely unpigmented. Dorsal hairs cylindrical, with pointed apex, quite short, on abdominal tergite III about .33-.40 of basal diameter of antennal segment III, but the 6 hairs on tergite VIII up to 1.33 times that diameter. Spinal tubercles on tergite VIII infrequently present, and usually very small and inconspicuous. Head with many nodules or blunt spinules on upper and underside, but an area enclosed by the spinal hairs on vertex is free, or very nearly free, of spinules. Frontal tubercles are, as typical for the subgenus, rather low; sinus frontalis wide, about two-thirds of diameter of frontal tubercles, with a hardly convex bottom; hairs on frontal tubercles at most half of basal diameter of antennal segment III. Antennae .70-.87 of length of body, pale, with segment I on inner side and the flagellum brownish to dark brown toward apex; segment III without rhinaria; hairs on segment III rather numerous, e.g., 13-19, very short, like those on frontal tubercles. Last rostral segment about $0.11 \mathrm{~mm}$ long, about .90.92 of second joint of hind tarsi, with normally 2 pairs of lateral hairs and 1-3 ventral hairs besides the 3 subapical pairs. Legs normal. Siphunculi rather short, .20-.25 of length of body, pale to very slightly pigmented, but quite dark at the very apex; with basal .33.40 part more or less cylindrical, and at its minimum 1.25-1.50 times as thick as the mid-portion of hind tibiae; markedly swollen on distal half to a maximum of 1.20-1.33 times the smallest diameter on basal half, or up to 1.67 times the diameter of mid-portion of the hind tibiae; about 6.00-6.50 times as long as their maximum width in the swollen area. Cauda .45-.50 of length of siphunculi, pale, more or less elongated triangular, with very blunt apex and often irregular outline caused by constrictions at, or just past, insertion points of the more basal 4 of the $6-8$ hairs. (See table 18.)

Collection data. All from Dianthus caryophyllus; specimens nos. 1-4, Richmond, Contra Costa County, California, March 6, 1964, leg. W. W. Allen (H.R.L., no. 158) ; specimens nos. 5 and 6, Sumner, Pierce County, Washington, November 26, 1958, leg. C. F. Doucette. 
TABLE 18

SAMPLE MEASUREMENTS OF MYZUS (NECTAROSIPHON) DIANTHICOLA n. sp. (Apterous Viviparous Females)

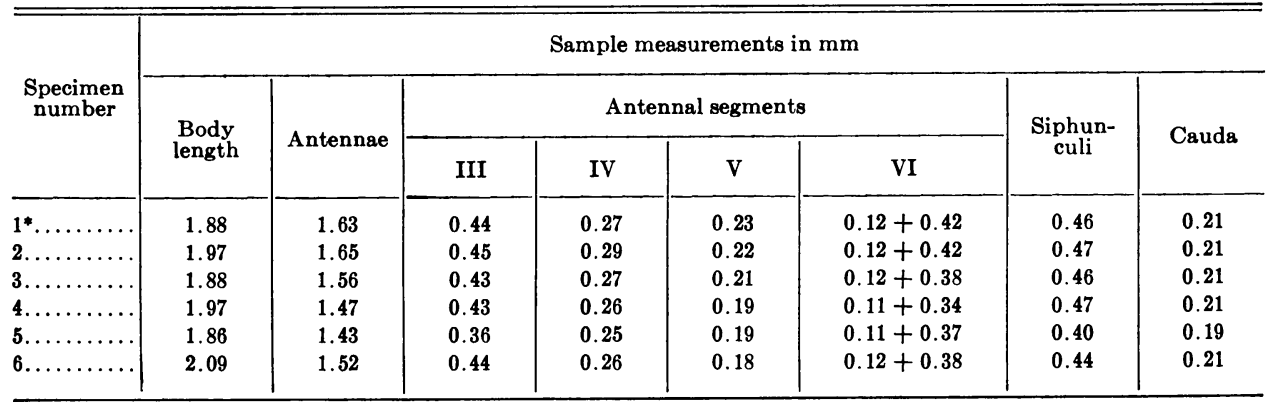

* Specimen no. 1 is the holotype.

\section{Alate viviparous female}

In life. With green abdomen, and with the usual blackish head and thorax and dark olive abdominal dorsal ornamentation.

In mounted specimens. Central sclerite on abdomen often has intersegmental perforations on the borders between segments III and IV and V and VI. No ventral sclerites present on abdomen. Antennae subequal to length of body; segment III with 11-18 rhinaria in a row, with often 1 duplicated, in 1 abnormal antenna with 9 ; no rhinaria on segment IV. Siphunculi less than one-fifth of length of body, dark, with the swollen area mostly mottled, about 6.50 times as long as their greatest width in the swollen area. Cauda dark, with slender, almost cylindrical, distal half. (See table 19.)
Collection data. Specimens nos. 1 and 2 with apterae nos. $1-4$; specimens nos. 3 and 4 with apterae nos. 5 and 6 .

Type material. Holotype: Apterous viviparous female from Dianthus caryophyllus, Richmond, Contra Costa County, California, March 6, 1964, leg. W. W. Allen (specimen no. 1 of measurements; H.R.L., no. 158). Paratypes: Apterae and alatae, with data as for holotype, and from Sumner, Pierce County, Washington, November 26, 1958, leg. C. F. Doucette.

Notes. Brierley and Smith (1957) recorded Myzus polaris Hille Ris Lambers, 1952, as causing severe injuries to carnation, Dianthus caryophyllus, from a great number of states in North America. I had identified as $M$. polaris material from Dianthus caryophyllus sent in by F. F. Smith. Since then,

TABLE 19

SAMPLE MEASUREMENTS OF MYZUS (NECTAROSIPHON) DIANTHICOLA n. sp. (Alate Viviparous Females)

\begin{tabular}{|c|c|c|c|c|c|c|c|c|c|}
\hline \multirow{3}{*}{$\begin{array}{l}\text { Specimen } \\
\text { number }\end{array}$} & \multicolumn{8}{|c|}{ Sample measurements in $\mathrm{mm}$} & \multirow{3}{*}{$\begin{array}{c}\text { Rhinaria on } \\
\text { antennal } \\
\text { segments III }\end{array}$} \\
\hline & \multirow{2}{*}{$\underset{\text { length }}{\text { Body }}$} & \multirow{2}{*}{$\begin{array}{c}\text { Anten- } \\
\text { nae }\end{array}$} & \multicolumn{4}{|c|}{ Antennal segments } & \multirow{2}{*}{$\begin{array}{l}\text { Siphun- } \\
\text { culi }\end{array}$} & \multirow{2}{*}{ Cauda } & \\
\hline & & & III & IV & V & VI & & & \\
\hline $3 \ldots \ldots \ldots$ & 1.84 & 1.80 & 0.47 & 0.34 & 0.27 & $0.14+0.44$ & 0.29 & 0.14 & 13 and 15 \\
\hline $4 \ldots \ldots \ldots$ & 1.74 & 1.91 & 0.52 & 0.36 & 0.28 & $0.14+0.45$ & 0.33 & 0.16 & 13 and 15 \\
\hline
\end{tabular}


much more material of $M$. polaris from the type area, eastern Greenland, has become available, and I have also had the opportunity of seeing Pacific carnation aphids in life. It appears to be necessary to describe this aphid as a new species, as it undoubtedly is different from the other taxa in the exceptionally difficult subgenus Nectarosiphon Schouteden, 1901.

The damage by this species is very striking, because of white or yellow blotches developing on infested carnations. The symptoms are very similar to those caused by the feeding of $M$. certus (Walker) on Cerastium spp., Dianthus spp., and especially Stellaria media in Europe and North America, including California."

Myzus certus, in all its larvae and adult morphs, is pink to blackish brown. The idea could not be maintained that $M$. dianthicola, which, as a larva, even in alatoid nymphs, is light green without a trace of pink, represented the green complement of $M$. certus. There is a consistent difference in the length of the processus terminalis. Since $M$. polaris Hille Ris Lambers, according to information received from Dr. J. Edwards, is green, the western carnation aphid was thought to be M. polaris, but this species appears to differ from $M$. dianthicola in having much thicker siphunculi, shorter pro- cessus terminalis, and considerably longer frontal and antennal hairs.

Brierley and Smith (1957) mention that I examined (in Washington, D.C.) material from carnation, and that $I$ identified it as $M$. polaris. I do not remember from which states this material came, but I should like to point out that from New Brunswick (MacGillivray, 1954) as far as California, M. certus (Walker) occurs on Caryophyllaceae; that this species can play havoc with carnations, but that it is pink, not green. Brierley and Smith also state that they could not establish colonies of M. persicae (Sulzer) on Dianthus caryophyllus, and for that reason doubt whether Aphis dianthi Schrank, 1801, really is a synonym of $M$. persicae. However, in Europe a polyphagous anholocyclic strain of $M$. persicae, to which sometimes the name $M$. dianthi Schrank has been given, occurs on $D i$ anthus. The latter strain, which in life is darker green and has more slender siphunculi than most other strains, does not cause specific damage to carnations.

It is extremely difficult to distinguish various described species of this subgenus, and it is virtually impossible to identify every single specimen of any of them. In the following key, characters apply to apterae viviparae of the second or later generations unless otherwise stated.

\section{Key to the Species of Myzus (Nectarosiphon)}

1(2). Second tarsal joints in all adult morphs with only 1-2 pairs of ventral hairs. Siphunculi in apterae on distal .50-.33 part blackish, pale on basal part. Cauda hardly longer than its basal width. Rolls the leaves of various Ligustrum spp. into tight cylinders and causes yellow spots. Europe, North America.

M. (N.) ligustri (Mosley, 1841) ${ }^{\circ}$

$2(1)$. Second tarsal joints in adults with 3 ventral pairs of hairs. Siphunculi in apterae evenly pigmented or with only the very apex dark. Cauda, except in starved specimens, 1.50 or more times as long as its basal width. Not on Ligustrum.

\footnotetext{
${ }^{5}$ In 1965 , some specimens were found in a vacuum sample from an alfalfa field near Bakersfield, California.

"Sometimes placed in "Amyzus H.R.L." (Eastop, 1951). I never published that generic name. It was used in a manuscript key to European aphid genera of 1937, which was copied with my permission by a visitor, and then, via secondary copyists, became widely known in England; later, marked "confidential," in North America.
} 
$3(4)$. Hairs on inner side of antennal segment III with pale, globular heads that are about twice as thick as thinnest part of hair. Hairs on vertex longer than hairs on anterior abdominal tergites. Basal part of siphunculi locally much thinner than mid-portion of hind tibiae. Polyphagous on herbaceous plants. All continents. $M$. (N.) ascalonicus Doncaster

4(3). Hairs on inner side of antennal segment III near apex mostly thicker than at base, but only very slightly so. Hairs on vertex about equal in length to hairs on anterior abdominal tergites. Minimum width on basal half of siphunculi mostly greater than diameter of mid-portion of hind tibiae.

$5(6)$. Last rostral segment 1.25-1.33 times as long as second joint of hind tarsi, with 7-11 hairs besides the 3 pairs near apex. Frontal tubercles on inner angle with at least 1 hair about as long as basal diameter of antennal segment III, the latter with some 15-23 hairs. Siphunculi very thick, on distal half up to twice as thick as mid-portion of hind tibiae, only 5-9 times as long as their maximum width on distal half. On Cerastium alpinum. East Greenland. $M$. (N.) polaris Hille Ris Lambers

6(5). Last rostral segment comparatively shorter, sometimes with 7 or more hairs besides the 3 subapical pairs, but then all hairs on inner side of frontal tubercles not, or hardly half, as long as basal diameter of antennal segment III.

$7(8)$. One or more of the hairs on inner side of frontal tubercles over threefourths of basal diameter of antennal segment III. Siphunculi normally less than one-fifth of length of body, very little swollen, only 7.00-8.50 times as long as their smallest width on basal half. Last rostral segment normally with only 2 hairs besides the 3 subapical pairs. Alatae nearly always with rhinaria on antennal segment IV, and often also on V. Viviparae green, oviparae red. On upper sides of leaves of Myosotis scorpioides (syn. M. palustris), folding the leaves upward into closed pods. Europe.

M. (N.) myosotidis Börner

$8(7)$. Hairs on inner side of frontal tubercles less than three-fourths of basal diameter of antennal segment III. Siphunculi usually over one-fifth of length of body, more or less distinctly swollen, and usually more than 8.50 times as long as their minimum width on basal half.

$9(10)$. Last rostral segment only exceptionally with a full complement of 2 pairs of lateral hairs, usually with 1 pair, with in addition $0-2$, rarely 3 , ventral hairs and sometimes 1 additional lateral hair, besides the 3 subapical pairs. Siphunculi in apterous viviparae normally pale, with or without a dark portion at the very apex, only in specimens grown at very low temperatures mottled-pigmented. Color of apterae viviparae of forms found in temperate climates, green, alatoid nymphs usually with some pink, oviparae after the first instar reddish, males alate. ${ }^{7}$ Alternating between Prunus (persica, nana, serotina, nigra) and Lycium as primary hosts, and a very great number of plant species as secondary hosts, but not on Ajuga spp., and with the exception of 1 anholocyclic strain ("dianthi Schrank"), not on Dianthus caryophyllus and related Dianthus spp. World-wide. $M$. (N.) persicae (Sulzer)

${ }^{7}$ One apterous gynandromorph with male genitalia, but without secondary rhinaria, was found in California. 
10(9). Last rostral segment either regularly with a full complement of 2 pairs of lateral hairs besides the 3 subapical pairs, or the siphunculi in all apterae viviparae more or less dark on parts other than the very apex. Males always apterous in those forms of which males are known.

11(12). Processus terminalis in summer apterae viviparae much to very much shorter than siphunculi, only rarely up to 3 times as long as base of segment VI. Color of larvae and all females pink to blackish brown. On various herbaceous plants, but especially Caryophyllaceae (Cerastium, Stellaria, Dianthus) and Viola arvensis. Europe, North America.

\section{$M$. (N.) certus (Walker)}

12(11). Processus terminalis often as long as or longer than siphunculi, usually more than 3 times as long as base of segment VI. Color of larvae and adults green.

13(14). In apterae viviparae, last rostral segment just longer than the short second joint of hind tarsi. Cauda with 4-6 hairs. Vertex without a distinct central area totally free of spinules or nodules. On the upper sides of the leaves of Ajuga reptans and A. genevensis, folding the leaves upward. Europe.

$M$. (N.) ajugae Schouteden

14(13). In apterae viviparae, last rostral segment just shorter than second joint of hind tarsi. Cauda with normally 7-9 hairs. Vertex with a rather large central area completely free of spinules. On Dianthus caryophyllus, causing white discoloration of leaves. (Western) North America.

M. (N.) dianthicola n. sp.

\section{Ovatus phloxae (Sampson, 1939)}

This species, recorded only from Phlox sp., Berkeley, Alameda County, California, either has a wide variety of host plants or it is part of a complex, the members of which infest several host plants. Mason's (1940) description of Myzus plantagineus Pass. is based on material also described by Williams (1911) and checked by Davis (1912) from Plantago major, Fremont, Dodge County, Nebraska, August 31, 1890, now in the United States National Museum, Washington, D.C. I checked this and found no difference from $\boldsymbol{O}$. phloxae (Sampson).

Dr. E. S. Sylvester and I found the species on the undersides of leaves of Polygonum paronychia in the dunes south of San Francisco, California. The small leaves of the host turned yellow or brown where an aphid had been feeding. A sample from lilies at San Diego, received from the California Department of Agriculture, was correctly determined by Prof. E. O. Essig as Phorodon phloxae Sampson.

\section{Paracolopha n. gen.}

Dryopeia morrisoni Baker, 1919, was described from the roots of Phyllostachys in Maryland, and seemingly had not been refound. However, a slide with the name Eriosoma lanigerum in the Essig collection contained some apterae of this bamboo-root aphid, found in a nursery in southern California. Prof.
C. F. Smith and I collected several under litter covering superficial roots of Arundinaria gigantea on the Orton plantation, South Carolina.

The most curious character of this aphid, although clearly shown in Baker's figures, is not mentioned in his description. The rather large siphunculi 
are not placed marginally, but subspinally. No other aphid that I know has this character. In Crypturaphis grassii Silvestri, 1935, alatoid nymphs have the siphunculi far dorsad, but in that case the sides of the body are flattened to a sort of wing, as in elm fruits, and adults have their siphunculi laterally placed.

Generic description. Paracolopha n. gen. is characterized as follows: Tarsi in apterae of one segment, the fore tarsi with two subapical strong spines on enlarged sockets ventrally. Siphunculi present in apterae, placed spino-pleurally instead of sublaterally. Wax glands without a hair, placed caudad of a hair, often with a distinct, very strongly transverse central cell.

Type species. Dryopeia morrisoni Baker, 1919.

Discussion. The genus is related to Colopha Monell, 1877, type Byrsocrypta ulmicola Fitch, 1859 (synonym Colophella Börner, 1926, type Tetraneura graminis Monell, $1882=$ Byrso- crypta ulmicola Fitch, 1859), but in that genus apterous exules have no siphunculi. Colophina Börner and Schilder, 1932, monotypical, with presumably as type, Eriosoma clematicolum Takahashi, 1924 (= Pemphigus clematicola Shinji, 1922, syn. Eriosoma clematis Shinji, 1922), differs in the apterous exules having normal fore tarsi, 1 or 2 tarsal segments, and (at least, according to Börner and Schilder [1932] and Stroyan [1963]) siphunculi. But Takahashi (1924) and Okamoto and Takahashi (1927) do not mention siphunculi, and I can find no trace of siphunculi in my material of apterous Colophina clematis Shinji from Clematis sp., identified by Dr. R. Takahashi.

Mordvilko (1935) suggests that morrisoni Baker may be part of the cyclus of Gobaishia ulmifusa (Walsh and Riley, 1869). If this should be true, then ulmifusa is not a Gobaishia Matsumura, 1917 (= Kaltenbachiella Schouteden, 1906), for in the latter genus, apterous exules have no siphunculi.

\section{Pentamyzus n. gen.}

Generic description. Antennae in all adult morphs have 5 segments, in apterae viviparae and oviparae without secondary rhinaria. Head myzine, with almost smooth frontal tubercles and a marked median tubercle. Abdomen in apterae without marginal or spinal tubercles, with the stigmal pori of tergites I and II rather close to each other. Dorsal or antennal hairs short, not capitate. Apterae viviparae with faintly sclerotic tergum, alatae without a distinct central sclerite on abdominal dorsum. Siphunculi clavate, not reticulated at apex. Cauda longer than wide at base. Hind tibiae of larvae not spinulose. First tarsal joints with $3,3,3$ hairs.

Type species. Pentamyzus graminis n. sp.

Discussion. The position of the abdominal stigmata I and II, as well as the shape of the front, demonstrates the relationship of Pentamyzus to the myzine group of genera. Within this group the nearest genus is Glabromyzus Richards, 1960 , from which it differs by its always 5 -segmented antennae. In view of experiences with other groups of aphids, the once-forked media of the genotype is not considered to be a generic character.

\section{Pentamyzus graminis n. sp.}

\section{Apterous viviparous female}

In life. Evenly green (but in alcohol with a median dorsal line); dorsum rather strongly convex, but venter flat or nearly so.
In mounted specimens. Body oval, rather broad, $1.60-2.00 \mathrm{~mm}$ long. Tergum not pigmented, hardly sclerotic, faintly wrinkled. Dorsal hairs very short, blunt, less than half as long as 
TABLE 20

SAMPLE MEASUREMENTS OF PENTAMYZUS GRAMINIS n. sp. (Apterous Viviparous Females)

\begin{tabular}{|c|c|c|c|c|c|c|c|}
\hline \multirow{2}{*}{$\begin{array}{c}\text { Specimen } \\
\text { number }\end{array}$} & \multirow{2}{*}{$\begin{array}{l}\text { Body } \\
\text { length }\end{array}$} & \multirow{2}{*}{ Antennae } & \multicolumn{3}{|c|}{ Antennal segments } & \multirow{2}{*}{$\begin{array}{l}\text { Siphun- } \\
\text { culi }\end{array}$} & \multirow{2}{*}{ Caude } \\
\hline & & & III & IV & V & & \\
\hline $1 *$. & 1.87 & 1.15 & 0.33 & 0.25 & $0.15+0.28$ & 0.26 & 0.20 \\
\hline $3 \ldots$ & 1.99 & 1.46 & 0.43 & 0.31 & $0.19+0.38$ & 0.29 & 0.20 \\
\hline $4 \ldots \ldots$ & 1.88 & 1.44 & 0.44 & 0.33 & $0.18+0.34$ & 0.30 & 0.19 \\
\hline $5 \ldots$ & 1.63 & 1.01 & 0.28 & 0.18 & $0.14+0.27$ & 0.22 & 0.19 \\
\hline $6 \ldots \ldots$ & 1.90 & 1.17 & 0.32 & 0.22 & $0.18+0.29$ & 0.23 & 0.19 \\
\hline
\end{tabular}

- Specimen no. 1 is the holotype.

diameter of antennal segment III at its constricted base. Marginal or spinal tubercles absent. Head with both upper and underside smooth, with only the very pronounced median tubercle and the angular frontal tubercles (which are almost twice as high) somewhat rough. Antennae uniformly brownish yellow, of 5 segments, .45-.75 of length of body; flagellum from base of segment III evenly imbricated; no secondary rhinaria present; base of last segment rather unusually long, about half as long as segment III; hairs on segment III very short, like dorsal body hairs. Eyes normal. Rostrum short, reaching the middle coxae; apical segment very short, about $0.070 \mathrm{~mm}$ long, nearly twothirds of second joint of hind tarsi, with only the 3 subapical pairs of hairs. Legs evenly brownish yellow; femora markedly and sharply imbricated distally; tibiae smooth, with few short hairs; the middle hair on first tarsal joints about five-sixths of the length of the lateral hairs. Siphunculi from pale brownish yellow to rather evenly dusky, at most gradually a little darker toward apex, .12-.14 of length of body, smooth, with basal half faintly wrinkled, at the thinnest place on basal half about 1.11-1.13 times as thick as diameter of the midportion of hind tibiae, at the thickest place on distal half about 1.50 times that diameter, attenuated just below the thin, somewhat wavy flange. Cauda slightly pigmented, slender, at basal two-fifths part slightly constricted, about 1.50 times as long as its basal width, blunt, .60-.90 of the siphunculi, with 5 hairs. (See table 20.)

Collection data. All from unidentified grasses; specimens nos. 1 and 2, Strawberry Canyon, Berkeley, Alameda County, California, March 15, 1964, H.R.L., no. 168; specimens nos. 3 and 4, 6 miles west of Beaumont, Riverside County, California, January 15, 1964, H.R.L., no. 124; specimens nos. 5 and 6, 10 miles east of Pope Valley, Napa County, California, March 17, 1964, H.R.L., no. 173.

\section{Alate viviparous female}

In life. With rather dark brown head and thorax; the veins of the wings rather heavy.

In mounted specimens. Head and thorax very dark brown; abdomen with irregular, rather narrow, vague, pale brownish transverse bars or rudiments of transverse bars on all, or on only some, tergites; with indistinct, very small marginal sclerites that on tergites II-IV often show a small, flat, marginal tubercle; tergites VII and VIII sometimes with similar spinal tubercles. Dorsal hairs almost twice as long as in apterae, just blunt, but the 4 hairs on tergite VIII pointed. Antennae darkish, 
TABLE 21

SAMPLE MEASUREMENTS OF PENTAMYZUS GRAMINIS n. sp.

(Alate Viviparous Females)

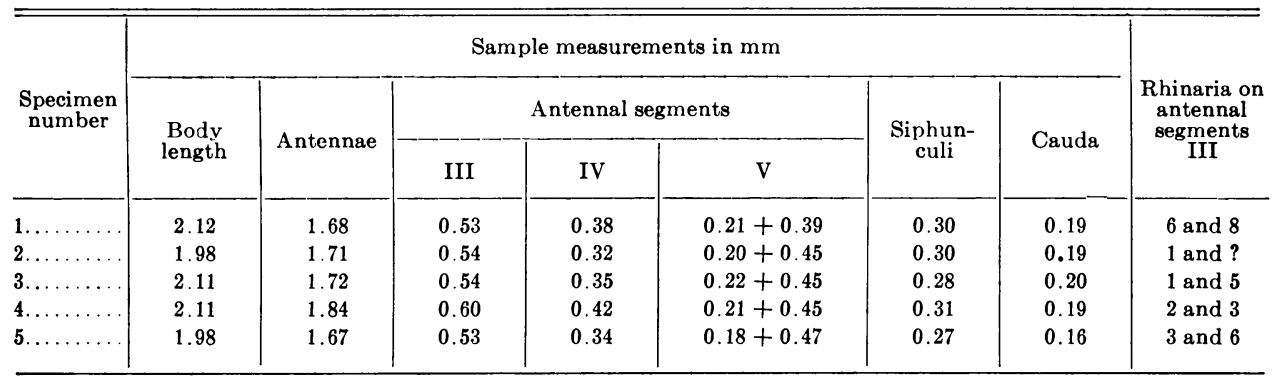

with only segment III lighter near base, about eight-ninths of length of body; segment III probably with abnormal sensoriation in most specimens, with 1-8 smallish rhinaria confined to basal half, not in a row, but if more than 3 are present, placed in clusters; base of last segment still unusually long. Legs brownish, with the apices of the femora darker dorsally. Wings with very thick, brownish veins, but with pale stigma; media in fore wings only onceforked, or in one specimen, simple; sector radii very little curved; hind wings with two obliques. Siphunculi $.14-17$ of length of body, with the stem just as thin, or thinner, than diameter of mid-portion of hind tibiae, on distal half to over 1.50 times that diameter, somewhat darker than in apterae. Cauda slightly darker than siphunculi, more slender than in apterae. (See table 21.)
Collection data. All were taken with apterae nos. 3 and 4 .

\section{Oviparous female}

In life. Like apterae viviparae, but with slightly darkened basal halves of the hind tibiae.

In mounted specimens. As in apterae viviparae, but hind tibiae with a conspicuous, very local swelling on basal one-third part, and only there on inner side with a cluster of 10-15 irregular pseudosensoria of varying sizes. Cauda sometimes with 1-2 additional hairs. (See table 22).

Collection data. All were taken with apterae nos. 5 and 6 .

\section{Apterous male}

In life. Evenly dark green, with dark antennae, slender.

In mounted specimens. Head pale brownish, but the rest of the body not

TABLE 22

SAMPLE MEASUREMENTS OF PENTAMYZUS GRAMINIS n. sp. (Oviparous Females)

\begin{tabular}{|c|c|c|c|c|c|c|c|}
\hline \multirow{3}{*}{$\begin{array}{c}\text { Specimen } \\
\text { number }\end{array}$} & \multicolumn{7}{|c|}{ Sample measurements in $\mathrm{mm}$} \\
\hline & \multirow{2}{*}{$\begin{array}{l}\text { Body } \\
\text { length }\end{array}$} & \multirow{2}{*}{ Antennae } & \multicolumn{3}{|c|}{ Antennal segments } & \multirow{2}{*}{$\begin{array}{l}\text { Siphun- } \\
\text { culi }\end{array}$} & \multirow{2}{*}{ Cauda } \\
\hline & & & III & IV & $\mathrm{V}$ & & \\
\hline $1 \ldots$ & 1.48 & 0.89 & 0.23 & 0.16 & $0.13+0.23$ & 0.20 & 0.14 \\
\hline $2 \ldots$ & 1.72 & 0.95 & 0.28 & 0.17 & $0.13+0.23$ & 0.23 & 0.16 \\
\hline $3 \ldots$ & 1.48 & 0.92 & 0.25 & 0.15 & $0.13+0.23$ & 0.23 & 0.16 \\
\hline $4 \ldots \ldots$ & 1.71 & 1.09 & 0.31 & 0.21 & $0.13+0.29$ & 0.26 & 0.18 \\
\hline
\end{tabular}


TABLE 23

SAMPLE MEASUREMENTS OF PENTAMYZUS GRAMINIS n. sp. (Apterous Males)

\begin{tabular}{|c|c|c|c|c|c|c|c|c|c|}
\hline \multirow{3}{*}{$\begin{array}{l}\text { Specimen } \\
\text { number }\end{array}$} & \multicolumn{7}{|c|}{ Sample measurements in $\mathrm{mm}$} & \multicolumn{2}{|c|}{$\begin{array}{l}\text { Rhinaria on antennal } \\
\text { segments }\end{array}$} \\
\hline & \multirow{2}{*}{$\begin{array}{l}\text { Body } \\
\text { length }\end{array}$} & \multirow{2}{*}{$\begin{array}{l}\text { Anten- } \\
\text { nae }\end{array}$} & \multicolumn{3}{|c|}{ Antennal segments } & \multirow{2}{*}{$\begin{array}{l}\text { Siphun- } \\
\text { culi }\end{array}$} & \multirow{2}{*}{ Cauda } & \multirow{2}{*}{ III } & \multirow{2}{*}{ IV } \\
\hline & & & III & IV & $\mathbf{v}$ & & & & \\
\hline & 1.39 & 1.32 & 0.43 & 0.27 & $0.14+0.34$ & 0.21 & 0.12 & 65 and \pm 72 & 26 and 31 \\
\hline 2. & 1.26 & 1.38 & 0.39 & 0.33 & $0.14+0.37$ & 0.22 & 0.12 & 63 and 66 & 22 and 24 \\
\hline
\end{tabular}

sclerotized and not pigmented. Antennae quite dark, as long as or longer than body; segment III covered with some 60-80 slightly tuberculate, very small rhinaria in which the porus is hardly wider than the width of the rim; segment IV with some 22-31 similar rhinaria, but base of $\mathrm{V}$ with none. Legs about as dark as the head. Siphunculi as in small apterae, but shorter. Cauda comparatively shorter. Genitalia dark, normal. (See table 23).

Collection data. Both were taken with apterae nos. 5 and 6.

\section{Larvae}

With completely membranous tergite; the hind tibiae apically lacking spinules among the hairs.

Notes. This species appears to be rather common in various parts of California, in colonies on the basal parts of low, unidentified grasses growing in somewhat moist environments at the sunless bases of north slopes. They are not visited by ants, are quite inconspic- uous on the plants, and are not likely to be found except by threshing over a piece of cardboard or paper held against the bases of the stems. The discovery of numerous oviparae and some apterous males in Napa County in March demonstrates that this aphid lives throughout the year on grasses; the fate of the black eggs could not be investigated. The alatae collected in Riverside County might be abortive in some respects, since their kind of antennal sensoriation is hardly normal.

Type material. Holotype: Apterous viviparous female (specimen no. 1 of measurements) from unidentified grass, Berkeley, Alameda County, California, March 15, 1964, leg. H.R.L., no. 168. Paratypes: Apterae with data as for holotype; apterae and alatae from grass, 6 miles west of Beaumont, Riverside County, California, January 15, 1964, leg. H.R.L., no. 124; apterae, oviparae, and males from grass, 10 miles east of Pope Valley, Napa County, California, March 17, 1964, leg. H.R.L., no. 173.

\section{Pleotrichophorus Börner, 1930}

According to material in the Essig collection, a considerable number of Pleotrichophorus species occur in California on Artemisia and Chrysothamnus species. I did not complete the identification of this material, and it is not considered here.
However, an effort was made to investigate the Pleotrichophorus on Artemisia californica, on which two species occur, on $A$. douglasiana, on which one species was found, and on an Achillea from which $P$. patonkus ( $\mathrm{H}$. and $\mathrm{F}$.) had been recorded from California. 


\section{Key to Four Species of Pleotrichophorus from California}

1(2). Siphunculi about 2.00-2.67 times as long as cauda, mostly thinnest near the middle and there .90-.95 times the diameter of mid-portion of hind tibiae. Common on Artemisia californica, but not found by me on other Californian Artemisia spp.

$P$. pseudoglandulosus (Palmer)

2(1). Siphunculi at most 1.50 times as long as cauda.

3(4). Siphunculi longer than cauda, in apterae about twice as long as second joint of hind tarsi. On Artemisia douglasiana, but not found on other Californian Artemisia species. Not common in California.

\section{$P$. gnaphalodes (Palmer)}

4(3). Siphunculi shorter than cauda, in apterae at most 1.50 times as long as second joint of hind tarsi.

5 (6). On abdominal tergite III, longest hairs in apterae about 1.50 times as long as the width of their knob. Last rostral segment elongated triangular, sometimes with very faintly concave sides, but apical one-fourth does not consist of a thin, cylindrical, needlelike part. In a pink and in a green form on lower leaves of Achillea sp. Rather common in California.

$P$. patonkus (Hottes and Frison)

6(5). On abdominal tergite III in apterae, longest hairs two or more times as long as the width of their knob. Last rostral segment with apical .25.29 part dark and needle-shaped; this part is usually separated by a nick from the basal part of the segment (difficult to see in specimens with flattened or dilated rostrum). On Artemisia californica. Not very common, and it is usually parasitized.

$P$. obscuratus n. sp.

\section{Pleotrichophorus obscuratus n. sp.}

\section{Apterous viviparous female}

In life. Because of the hairs, seemingly pruinose, grayish green, not having a brighter median stripe; siphunculi rather dark at tips; cauda, subanal, and particularly subgenital plate sometimes conspicuously dark; adults appear larval.

In mounted specimens. Head, antennae, mesosternal furca, legs, stigmal plates, cauda, subanal plate, especially the subgenital plate, and to some extent, siphunculi, more or less pigmented to blackish, the rest colorless. Dorsal hairs very numerous and in random arrangement, on large sockets, with cylindrical basal half, fanning out from the middle to a wide, funnel-shaped apex; longest hairs on abdominal tergite III, without their sockets, about 1.80-2.20 times the basal diameter of antennal segment III, with the width of their apex about .33.50 of the length of the hair; vertex with about 16-20 hairs. Ventral hairs fine and acute, including the hairs on the clypeus, but the hairs on the underside of the head are still thick, stiff, and with more or less widened apices. Front with median tubercle half or more as high as the frontal tubercles, with hairs that, without sockets, are about as long as antennal segment II. Antennae variable in pigmentation, about .86-1.10 times the length of body; basal segments without capitate hairs, but segment I on outer side, approximately halfway along its length, with a hair longer than basal diameter of segment III; on inner 
TABLE 24

SAMPLE MEASUREMENTS OF PLEOTRICHOPHORUS OBSCURATUS n. sp. (Apterous Viviparous Females)

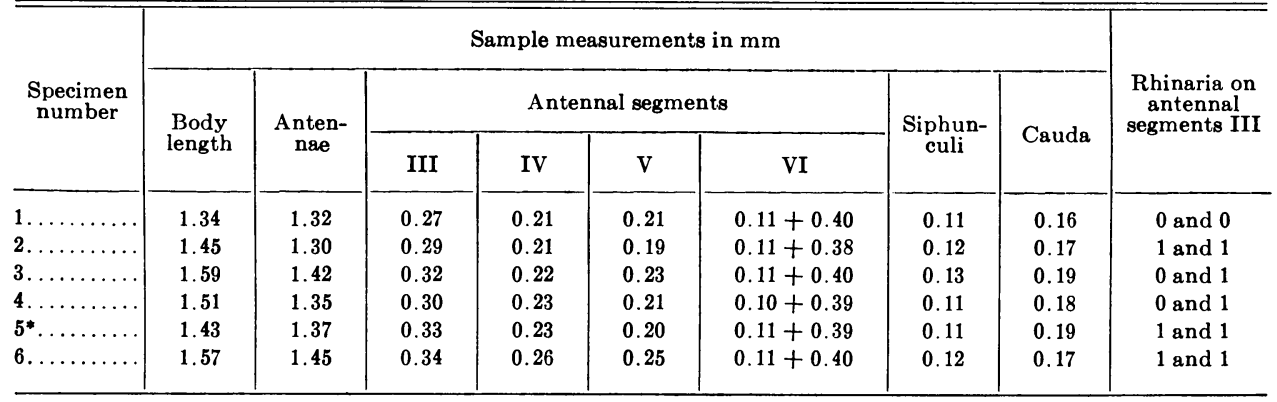

* Specimen no. 5 is the holotype.

side, with very short, blunt hairs; flagellum from base of segment III very lightly imbricated; segment III with 0-1 rhinarium near base, both segments III occasionally, but rarely, lacking rhinaria; hairs on III about half as long as basal diameter of segment, just blunt. Eyes are as typical for genus. Rostrum reaching to hind coxae; last segment dark, stiletto-shaped, with the distal one-third part parallel-sided, needleshaped; length about 0.11-0.12 $\mathrm{mm}$, slightly longer than base of last antennal segment or second joint of hind tarsi, with 4 very long hairs on basal part, the much shorter 3 pairs of subapical hairs placed so far from the apex that the most distal pair stands halfway along the segment. Legs variably pigmented; hairs on outer side of the midportion of the hind tibiae about threefifths of local diameter of those tibiae. Siphunculi quite short, about as long as second joint of hind tarsi, darkish, denticulate imbricated, very slightly tapering, often with a very light constriction both at base and apex, and with a small flange. Cauda bluntly triangular, with a slight bulge near base, dark or darkish, about 1.67 times as long as its basal width and about 1.50 times as long as siphunculi, with 5 hairs. (See table 24.)

Collection data. Specimens nos. 1-5 from Artemisia californica, Berkeley,
Alameda County, California, February 2, 1964, leg. H.R.L., no. 141; specimen no. 6 from Artemisia sp., Pico Creek, San Luis Obispo County, California, August 6, 1962, leg. R. van den Bosch and E. Schlinger, no. 62-8-6f.

Notes. Only once were healthy colonies of this species found in the winter of 1963-1964, in Strawberry Canyon, Berkeley, Alameda County, California, where one out of several hundred plants of Artemisia californica had this aphid. In other parts of California (Los Gatos, Santa Cruz, Monterey, Big Sur, Riverside), where Pleotrichophorus pseudoglandulosus was common and healthy, threshing mostly produced one or two specimens of $P$. obscuratus that invariably turned into mummies.

It is with great reluctance that this aphid is described as new. So far, 5 similar Pleotrichophorus with the siphunculi shorter than the cauda have been described: $P$. bitrichus Knowlton and Smith, 1936; P. brevinectarius Gillette and Palmer, 1933; $P$. filifoliae Palmer, 1938; $P$. heterohirsutus Gillette and Palmer, 1933; and $P$. infrequens Knowlton and Smith, 1936. Of these, $P$. bitrichus and $P$. heterohirsutus, which may be one species, differ by having rather long antennal hairs and a mixture of capitate and normal hairs on the front. $P$. brevinectarius differs by its long 
cauda (3 times the siphunculi) and long processus terminalis ( 5 times the base of VI). P. filifoliae, according to Palmer's description, is very similar, but has the antennae considerably longer than the body, with a longer processus terminalis $(4.17-5.17$ times the base of VI), and 2 dorsoapical hairs on cauda instead of 1 . This leaves $P$. infrequens, which has nearly all the requirements, such as rather short antennae with a short processus terminalis $(3.50-4.00$ times the base of VI), but its dorsal hairs are about half as long as those of $P$. obscuratus, and they have a very short stalk. Unfortunately, no types of the other species are available.

Type material. Holotype: Apterous viviparous female (specimen no. 5 of measurements) from Artemisia californica, Berkeley, Alameda County, California, February 2, 1964, leg. H.R.L., no. 141. Paratypes: Apterae with data as for holotype.

\section{Rhopalomyzus Mordvilko, 1921}

Hille Ris Lambers (1953) wrote that Rhopalosiphum grabhami Cockerell, 1903, differs from Rhopalosiphum poae Gillette, 1908, the type species of Rhopalomyzus, and that the latter species overwinters as eggs on Lonicera spp. Gillette and Palmer (1932) and Palmer (1952) suspected host alternation in grabhami, and thought that poae might be part of its cyclus. In September, 1.956, Dr. F. C. Hottes and I found, among several gynoparae of grabhami, one gynopara of poae on Lonicera involucrata, which suggests that also in America, poae can overwinter on Lonicera. The summer hosts of grabhami remained unknown.
Rhopalomyzus poae occurs in California. I identified a slide in the Essig collection. $R$. grabhami had been recorded earlier from Lonicera "ledebouri" by Essig; also, Hille Ris Lambers (1953). A second-instar larva which I found on grass on Point Reyes peninsula, Marin County, California, was bred to maturity on Poa annua, and produced about five generations of apterous progeny. It appeared to be grabhami Cockerell, and unidentified material in the Essig collection showed that it had been found before. The undescribed apterous exules are very different from those of poae, so I add descriptions of this morph as well as of the undescribed oviparae.

\section{Rhopalomyzus grabhami (Cockerell, 1903)}

\section{Apterous viviparous female}

In life. Greenish black, slightly shiny, conspicuously swollen. Legs, antennae, etc., dark.

In mounted specimens. Head dark sclerotic, thorax and abdomen dorsally with transverse rows of roundish to oval sclerotic plates that are much less pigmented than the head; depending on the size of these plates, each bears, on rather large, tall sockets, 1-3 dark, stiff, rather slender hairs, $0.040-0.065 \mathrm{~mm}$ long, with a small, colorless knob; dorsal hairs from front to tail up to about the same length, not in simple, transverse rows on the abdomen, but in irregular, double rows, and not in a definite pattern; tergite VIII has 4 hairs. Marginal tubercles apparently absent. Head dorsally and ventrally with unusually small and short, subacute spinules, at first glance seemingly smooth, but actually with as many spinules as a rough myzine head. Median tubercle pronounced, .33-.50 of the height of the somewhat divergent frontal tubercles, which are rounded on the inner side, but seemingly angular through hair sockets. Antennae very conspicuously curved to about onefourth of a circle (apex of processus terminalis at right angle to base of segment III), a little longer than body, dark, with the undersides of segments 
TABLE 25

SAMPLE MEASUREMENTS OF RHOPALOMYZUS GRABHAMI (Cockerell, 1903) (Apterous Viviparous Females)

\begin{tabular}{|c|c|c|c|c|c|c|c|c|}
\hline \multirow{2}{*}{$\begin{array}{c}\text { Specimen } \\
\text { number }\end{array}$} & \multirow{2}{*}{$\underset{\text { length }}{\text { Body }}$} & \multirow{2}{*}{ Antennae } & \multicolumn{4}{|c|}{ Antennal segments } & \multirow{2}{*}{$\underset{\text { culi }}{\text { Siphun- }}$} & \multirow{2}{*}{ Cauda } \\
\hline & & & III & IV & $\mathrm{V}$ & VI & & \\
\hline $1 \ldots \ldots$ & 1.57 & 1.71 & 0.40 & 0.28 & 0.25 & $0.12+0.52$ & 0.28 & 0.09 \\
\hline $3 \ldots \ldots$ & 1.64 & 1.66 & 0.38 & 0.26 & 0.25 & $0.12+0.51$ & 0.28 & 0.10 \\
\hline $4 \ldots$ & 1.49 & 1.67 & 0.39 & 0.27 & 0.22 & $0.12+0.52$ & 0.26 & 0.09 \\
\hline $5 \ldots$ & 1.38 & 1.53 & 0.35 & 0.23 & 0.22 & $0.11+0.47$ & 0.25 & 0.09 \\
\hline $6 \ldots$ & 1.57 & 1.69 & 0.40 & 0.28 & 0.23 & $0.11+0.51$ & 0.28 & 0.09 \\
\hline
\end{tabular}

I and II and all of the flagellum imbricated; segment III without rhinaria; longest hairs on segment I up to 1.50 times the basal diameter of segment III, those on III up to about as long as the basal diameter of that segment, all with a faint, pale knob. Rostrum reaching to just past the middle coxae, apical segment short, but still 1.33 times as long as the quite small second joints of hind tarsi, with 3-5 hairs besides the 3 subapical pairs. Legs darkish, with apically inconspicuously denticulate-imbricated femora and smooth tibiae; hairs on outer side of mid-portion of hind tibiae, without their sockets, are about fivesevenths of the local diameter of those tibiae; first tarsal joints with 3,3,2 hairs. Siphunculi with basal four-ninths and apical one-seventh part cloudily dark, the intervening part from pale to cloudy; length about one-sixth of that of body; at the very base usually dilated, then suddenly narrower, and very shortly after gradually widening to a maximum at two-thirds of their length, from where they taper to the rather narrow, flanged apex; smallest width on basal half about 1.29-1.43 times the diameter of mid-portion of hind tibiae; maximum width on distal half 1.71-1.79 times that diameter, near apex a little thinner than that diameter; surface smooth, with 2-3 transverse striae below the rather thin flange. Cauda about as long as its basal width, slightly atten- uated near base and near two-thirds of its length, bluntly triangular, dark, with normally 5 , sometimes 6 , hairs. (See table 25.)

Collection data. Specimens nos. 1-3 from grass, Inverness, Marin County, California, March 14, 1964, leg. H.R.L., no. 165; specimens nos. 4-6 as before, March 21, 1964, leg. H.R.L., no. 180.

\section{Oviparae}

In life. Color unknown.

In mounted specimens. Much like apterous exules, but hair-bearing sclerites on dorsum much smaller and paler, very inconspicuous; dorsal hairs similar as to length, but with lower sockets, thinner shafts, and more lanceolate apices, less numerous, but tergite VIII with up to 20 hairs. Vertex only laterally rough. Frontal tubercles merely indicated. Antennae only about .71-.79 of length of body, not conspicuously curved, of 6 or (because of complete obsoleteness of division between III and IV) of 5 segments; hairs on III comparable to those of exules only on basal half, much shorter, more distad. Siphunculi not at all swolien, very slightly tapering from base to apex, where they are faintly narrowing, less than one-tenth the length of body, dusty to brownish, with paler base, with some scattered spinules. Cauda thick and very blunt, with about 7-9 hairs. Hind tibiae rather evenly 
TABLE 26

SAMPLE MEASUREMENTS OF RHOPALOMYZUS GRABHAMI (Cockerell, 1903)

(Oviparae)

\begin{tabular}{|c|c|c|c|c|c|c|c|c|}
\hline \multirow{2}{*}{$\begin{array}{c}\text { Specimen } \\
\text { number. }\end{array}$} & \multirow{2}{*}{$\begin{array}{r}\text { Body } \\
\text { length }\end{array}$} & \multirow{2}{*}{ Antennae } & \multicolumn{4}{|c|}{ Antennal segments } & \multirow{2}{*}{$\begin{array}{l}\text { Siphun- } \\
\text { culi }\end{array}$} & \multirow{2}{*}{ Cauda } \\
\hline & & & III & IV & V & VI & & \\
\hline $1 \ldots \ldots \ldots$ & 1.45 & 1.14 & 0.20 & 0.14 & 0.20 & $0.10+0.38$ & 0.13 & 0.08 \\
\hline $3 \ldots \ldots \ldots$ & 1.52 & 1.11 & 0.33 & 0.17 & $0.11+0.38$ & - & 0.14 & 0.07 \\
\hline
\end{tabular}

incrassate, not with calves, at their maximum width only about 1.50 times diameter of mid-portion of middle tibiae, with some 50-60 pseudosensoria. (See table 26.)

Collection data. Specimens nos. 1-3 from Lonicera involucrata, Fort Bridger, Uinta County, Wyoming, September 14, 1959, leg. G. F. Knowlton.

Notes. The life cycle of this species appears to be that the first generation rolls the leaves of Lonicera involucrata and its subspecies. The second generation consists of alatae, which fly away and colonize grasses, where their progeny develop on the lowest parts of the stems, underground or partly underground. Gynoparae, developed on grass, return to Lonicera, where their feeding causes bright yellow blotches on the leaves, as with all other members of the genus Rhopalomyzus. Gynoparae and males were found in Colorado at 6,000 feet (Hottes and Hille Ris Lambers) from September 7 to 17, and adult ovi- parae in Wyoming (Knowlton) on September 14. However, F. C. Hottes gave me a slide of gynoparae from Lonicera involucrata collected on August 3, 1952. Also, a slide of damaged males collected on September 7, 1951, by Hottes contains one alatoid nymph. Apterae viviparae have not been found on Lonicera; four apterae (September 7, 1951, Skyway, Colorado, 6,000 feet) from Lonicera appear to be parasitized alatoid nymphs.

Experimental transferences between Lonicera and grass have not been made, but the embryos inside spring migrants are very typical because of their chaetotaxy, and are identical with those inside apterous exules. Oviparae are somewhat different, and would not be placed in this genus if one did not know their mothers. The species, because of the long, somewhat knobbed, dorsal hairs of its exules, might be very easily mistaken for a member of a Capitophorus-like genus.

\section{Rhopalosiphoninus subgen. Myzosiphon Hille Ris Lambers, 1946}

In 1946, I applied the generic name Myzosiphon to Rhopalosiphum staphyleae Koch, 1854, to which species Börner $(1950,1952)$ gave the subgeneric name Arthromyzus. In 1953 I, like everyone else, overlooked Myzosiphon Hille Ris Lambers, 1946, and listed Arthromyzus Börner as a synonym of Rhopalosiphoninus Baker, 1920, a further subdivision of which genus was not then con- sidered justifiable. More recent developments make it more logical to apply a subgeneric name to the group to which staphyleae Koch, 1854, tulipaellus Theobald, 1916, and persimilis Hille Ris Lambers, 1960, belong.

The three species mentioned occur in North America. $R$. (M.) staphyleae (Koch) has been introduced into California, probably with tulip bulbs, and 
maintains itself on native plants, e.g., Dentaria sp. and Oxalis oregana, in Strawberry Canyon, Berkeley. $R$. (M.) tulipaellus (Theobald) has been caught in a Moericke trap in Pennsylvania by Dr. J. O. Pepper, of Pennsylvania State College. R. (M.) persimilis Hille Ris Lambers was described from Canada, but apparently had been described long before from the United States.

The discovery of an infestation by tulipaellus on tomato roots in the Netherlands led to the suspicion that Megoura solani Thomas, 1879 , described from tomato, might belong to Myzosiphon. Dr. L. J. Stannard, of Urbana, Illinois, most kindly compared material of the three species mentioned with Thomas' types, and sent me photographs and sketches. It is evident that M. solani Thomas is a Myzosiphon, and almost certainly is an older name for Myzosiphon persimilis Hille Ris Lambers. Dr. Stannard gave the length of the bluntish hairs on antennal segment III of the alate holotype of Megoura solani as $0.020 \mathrm{~mm}$, while it is up to
$0.021 \mathrm{~mm}$ in the longest hair in alate paratypes of persimilis, which is well outside the range of staphyleae and tulipaellus. The longest known hairs on antennal segment III of the last-mentioned species measure $0.016 \mathrm{~mm}$. Dr. Stannard comments on the shorter antennal segment III $(0.410 \mathrm{~mm})$ in the types of solani against $0.47-0.54 \mathrm{~mm}$ in the type material of persimilis, but in view of the antibiosis effect of tomato on $R$. (M.) tulipaellus, this might be expected. Another difference in the solani type, the rough apical part of antennal segment III mentioned by Dr. Stannard, is a character that varies considerably, even within clones of tulipaellus and staphyleae, and is somewhat obscured by too intensive potash treatment in the paratypes of persimilis. It would therefore seem that Rhopalosiphoninus persimilis Hille Ris Lambers, 1960 , must be considered as a svnonym of Megoura solani Thomas, 1879, which is placed in Myzosiphon Hille Ris Lambers, 1946, subgenus of Rhopalosiphoninus Baker, 1920.

\section{Sitobion Mordvilko, 1914}

Often used as a subgenus of Macrosiphum Pass., 1860, for species with short antennal hairs and small frontal tubercles; with, in apterae, very few rhinaria on antennal segment III, and often a more or less sclerotic dorsum; with, in alatae, rhinaria in mostly single file on antennal segment III and conspicuous pleural sclerites on abdomen; most are grass feeders, with a correspondingly short last rostral segment. Four species were found in California.

\section{Key to Four Species of Sitobion from California}

1(2). Siphunculi 3-4 times as long as the short cauda, in apterae with only 1-3 rows of hexagonal cells at apex; in alatae with more reticulations, and basad, to at least the middle of the siphunculi, with anastomosing lines which actually are broad, flat imbrications. On Rhamnus californica and $R$. purshiana.

S. rhamni (Clarke)

2(1). Siphunculi not more than 2.50 times as long as cauda, in apterae with more rows of hexagonal cells at apex. On Gramineae.

3(4). Siphunculi in apterae pale, at most somewhat dusky toward apex, at base twice as wide as at apex, very evenly tapering, their mid-portion about 1.70 times as wide as the mid-portion of the hind tibiae. On Elymus mollis and Ammophila arenaria.

S. sylvesteri $\mathrm{n} . \mathrm{sp}$.

${ }^{8}$ A fifth may be expected on Pennisetum spp., with which African grasses S. pauliani Remaudière has been introduced from Madagascar into Central America. 
4(3). Siphunculi, only in apterae on Rubus, pale, with blackish apex; on other hosts, entirely blackish; their mid-portion less than 1.50 times as wide as the mid-portion of the hind tibiae.

5(6). Siphunculi with at most apical one-fifth part reticulated, about 1.75-2.50 times as long as cauda, the latter about 2.00-2.67 times as long as last rostral segment. Overwintering as eggs on Rubus spp.; alternate hosts are various Gramineae.

S. fragariae (Walker)

6(5). Siphunculi with at least apical one-fourth part reticulated, 1.10-1.43 times as long as cauda, the latter 3 or more times as long as last rostral segment. Without host alternation on Gramineae; more rarely on Iris, Capsella, Spergula, etc.

S. avenae (Fabricius)

\section{Sitobion avenae (Fabricius, 1775)}

This species has been recorded from California as Macrosiphum granarium Kirby, but most, if not all, of these records appear to relate to $S$. fragariae. I could not find $S$. avenae myself, but
I identified some specimens in alfalfa sweeps from Riverside, California. Perhaps it is more common in Califormia in other seasons than winter. It is very common in the eastern states.

\section{Sitobion fragariae (Walker, 1848)}

This aphid had not been recorded earlier from North America under this name, but Macrosiphum harpagorubus Knowlton, 1935, later (Knowlton and Allen, 1937) M. rubiellum subsp. harpagorubus from Rubus laciniatus, Puyallup, Pierce County, Washington, is a synonym. In Europe, the species has host alternation between Rubus and Gramineae, but assuming that it may do so in California, I found it to be quite common on grasses in that state during the winter. It differs from $S$. avenae, not only by relatively and absolutely longer siphunculi, but also by an absolutely shorter cauda. This would seem to be the common Sitobion on grasses in California. I found it wherever I looked for it, from Napa County to San Diego County.

\section{Sitobion rbamni (Clarke, 1903)}

This species has been placed in Myzus Pass. and Macrosiphum Pass. Alatae offer no problem, since they come close to Macrosiphum with their reticulated siphunculi. The short antennal hairs, low frontal tubercles, and distinct me- dian tubercle indicate that they belong in Sitobion. But apterae, because their siphunculi are hardly reticulated, would not be classified as Sitobion if they were the only specimens seen. The life cycle is not yet known.

\section{Sitobion sylvesteri $\mathrm{n}$. sp.}

\section{Apterous viviparous female}

In life. Dull, light green, with a distinct, brighter green median line down the dorsum. Siphunculi very pale green, with more or less dusky distal half. Antennae pale, gradually darker from segment $\mathrm{V}$ to apex, not with dark tips on segments III and IV.
In mounted specimens. Body completely unpigmented, about $1.80-3.00$ $\mathrm{mm}$ long. Tergum smooth. Dorsal hairs sparse, stiff, with just incrassate blunt tips, on abdominal tergite III about $.57-.71$ of basal diameter of antennal segment III, the 4 hairs on tergite VIII up to 1.50 times that diameter. Marginal tubercles on abdominal tergites 
TABLE 27

SAMPLE MEASUREMENTS OF SITOBION SYLVESTERI n. sp.

(Apterous Viviparous Females)

\begin{tabular}{|c|c|c|c|c|c|c|c|c|c|}
\hline \multirow{2}{*}{$\begin{array}{c}\text { Specimen } \\
\text { number }\end{array}$} & \multirow{2}{*}{$\begin{array}{l}\text { Body } \\
\text { length }\end{array}$} & \multirow{2}{*}{$\begin{array}{c}\text { Anten- } \\
\text { nae }\end{array}$} & \multicolumn{4}{|c|}{ Antennal segments } & \multirow{2}{*}{$\begin{array}{l}\text { Siphun- } \\
\text { culi }\end{array}$} & \multirow{2}{*}{ Cauda } & \multirow{2}{*}{$\begin{array}{l}\text { Rhinaria on } \\
\text { antennal } \\
\text { segments III }\end{array}$} \\
\hline & & & III & IV & $\mathrm{V}$ & VI & & & \\
\hline $3 \ldots \ldots \ldots$ & 2.79 & 2.12 & 0.53 & 0.32 & 0.33 & $0.15+0.59$ & 0.53 & 0.33 & 2 and 2 \\
\hline $4 \ldots \ldots$ & 2.62 & 1.90 & 0.49 & 0.32 & 0.28 & $0.14+0.47$ & 0.55 & 0.31 & 2 and 3 \\
\hline $5 \ldots$ & 3.16 & 2.38 & 0.66 & 0.40 & 0.37 & $0.15+0.59$ & 0.63 & 0.37 & 2 and 3 \\
\hline $6 \ldots$ & 1.83 & 1.54 & 0.37 & 0.21 & 0.22 & $0.11+0.46$ & 0.35 & 0.22 & 1 and 2 \\
\hline
\end{tabular}

- Specimen no. 1 is the holotype.

II-V regularly present, with a diameter of about the length of the nearest hair and rather elevated; the one on tergite $\mathrm{V}$ about as high as its basal width; spinal tubercles apparently absent. Head smooth, frontal tubercles low, very strongly divergent, about twice as high as the very pronounced, broad, median tubercle. Antennae only twothirds to, in very small specimens, seven-eighths of length of body, pale, with a dark tip from the apex of segment IV or $\mathrm{V}$, imbricated from about the middle of segment IV apicad; segment III with 1-3, rarely 0, small, slightly elevated rhinaria near base; hairs on segment III to about four-sevenths of basal diameter of the segment. Rostrum reaching to just past middle coxae; apical segment about nine-tenths of second joint of hind tarsi, rather slender for the genus, with 4-7 hairs besides the 3 subapical pairs. Legs pale, with the extreme apices of the tibiae dusky; the tarsi blackish brown, smooth, with the middle and hind femora faintly imbricated ventrally near apex; longest hairs on outer side of mid-portion of hind tibiae just over half local diameter of the tibiae; first tarsal joints with $3,3,3$ hairs. Siphunculi .18-.20 of length of body, pale, with slightly darkened apices, thick, about 7.50 times as long as the diameter of their mid-portion, gradually tapering to just before apex, where they expand a little; at base twice as wide as near apex, where they are still about 1.40 times as thick as the mid-portion of the hind tibiae, rough, by semiblunt nodules, passing into imbrications at about three-fourths of their length; reticulated with rather fine, sometimes elongate, meshes over distal one-fifth part, with trumpetlike, but almost flangeless, apex. Cauda pale, about three-fifths of the length of the siphunculi, rather thick, not at all constricted, rather gradually tapering over three-fourths of its length and a little more over the distal one-fourth part, not very blunt, with $8-10$, rarely 7 , hairs. Subgenital plate with only about 7-10 hairs along posterior margin. (See table 27.)

Collection data. Specimens nos. 1, 4, and 6 from Elymus mollis, San Francisco, California, December 29, 1963, leg. H.R.I., no. 110; specimens nos. 2, 3 , and 5 as before, but November 24, 1963, leg. H.R.L., no. 92.

Notes. Colonies of this species were found at the very bases of the leaves of Elymus mollis, and sometimes of Ammophila arenaria, growing in loose sand just above the beach at San Francisco, near Fleishhacker Zoo. Only a very few clumps of the grasses were infested, and by April, coccinellids and the larvae of a syrphid fly had destroyed the aphids. In life, the species resembled Metopolo- 
phium dirhodum (Walker), but its body was not so elongate and the siphunculi were much thicker. Neither alatoid nymphs nor alatae were found.

The thick, pale siphunculi, with their unusually fine reticulation, and the nonconstricted, subacute cauda distinguish this Sitobion from all the many other grass-feeding species.
Type material. Holotype: Apterous viviparous female (specimen no. 1 of measurements) from Elymus mollis, San Francisco, California, December 29, 1963, leg. H.R.L., no. 110. Paratypes: Apterous females with data as for holotype; also, other individuals that were collected on November 24, 1963, leg. H.R.L., no. 92.

\section{Stegopbylla Oestlund, 1922}

In a study of a Stegophylla, common on both evergreen and deciduous oaks in California, it was necessary to reexamine North American data on several species of the genus. The confusion in nomenclature of the species would seem to be worse than in any other genus of aphids.

Fitch (1859) described, as Eriosoma querci nov. spec., a woolly aphid from oak twigs from northern Illinois, which he likened to a similar insect (Tiliphagus Smith) on basswood (Tilia sp.), but he described alatae that were not woolly and clearly belonged to another species. Baker (1916) re-examined the Fitch alatae, and found them to be of an Anoecia that belongs on dogwood (Cornus sp.) and grass, that never in its life is woolly, and does not feed on oak; thus, Baker referred Eriosoma querci to Anoecia. His selection of neotypes, even if accepted by several other workers, must be rejected because Fitch described a woolly aphid, not an Anoecia.

Davis (1911), referring to descriptions of similar insects by Fitch (1859), Cowen (1895), and manuscript notes by Davidson, gives, under the name Phyllaphis querci Fitch(?), an extensive description of woolly aphids collected on oak in northern Illinois.

Baker (1916), after his unfortunate lectotype selection of querci Fitch, thought that the insects referred to as querci Fitch by Cowen (1895), Davidson (1910), and Davis (1911) were all the same species (although he quoted Gillette [1914] as renaming Cowen's insect and distinguishing it from Davis' species). He then wrote that "the insect referred to by Davis if not by Davidson is a very distinct species, ${ }^{\circ}$ which may be known as Phyllaphis quercicola $\mathrm{n}$. n." I assume that quercicola Baker, 1916 , is a new name for only the insect described by Davis (1911), for the one referred to by Davidson is another species. Hottes and Frison (1931) wrote that they found alate males in southern Illinois, and apterous males in central Illinois (Urbana), which might point to two species. But Davis (1911) found both alate males and an apterous male in northern Illinois (Chicago). I have seen one species from Illinois, but a different one from Wisconsin (Milwaukee) which one also might expect in northern Illinois; therefore, two species almost certainly occur in Illinois.

As Fitch's material of his actual Eriosoma querci is not known, there is no objection to applying the name querci Fitch to the woolly aphid that Davis (1911) described from the same part of Illinois as that from which Fitch described his aphid. Fortunately, Davis gave a description of the rostrum and figures which make it possible to recognize with certainty which of the two Illinois species he described. Antennal segment II, in his apterae, is less than 2.50 times as long as the width of its mid-portion (figure), and the rostrum rarely reaches the middle

\footnotetext{
Distinct from Anoecia.-H.R.L.
} 
coxae. Such specimens are available from Milwaukee, Wisconsin (October 3, 1934, leg. L. S. Strom). Characteristic is the very short last rostral segment, which is only $0.070-0.075 \mathrm{~mm}$ long, as long as antennal segment III, .75-.80 of second joint of hind tarsi. This, then, is to be considered as Stegophylla querci (Fitch, 1859), of which Phyllaphis quercicola Baker, 1916, is a synonym.

Monell (see Riley and Monell, 1879) described, as Callipterus(?) quercicola nov. spec., two alatae from oak found at St. Louis, Missouri. Hottes (1934) reexamined these specimens and found them to be Stegophylla, alate males. Monell referred to the apical joint of the rostrum as being very acute. This could not possibly apply to what has been mentioned above as Stegophylla querci (Fitch), but it does apply to a Stegophylla that I have from Quercus phellos at Raleigh, North Carolina. In this case, the last rostral segment is, in apterae viviparae, acute and triangular, with almost straight sides, in contrast to Stegophylla material from all other American sources; it bears 4-5 hairs besides the 3 apical pairs, 1 pair of which is placed far basad.

Stegophylla quercifoliae (Gillette, 1914) (new name for querci Cowen, 1895 ) is available in some quantity as apterae viviparae from two native oaks, Quercus gunnisoni and $Q$. gambelli, from Colorado and Utah. Apterae viviparae have the last rostral segment rather blunt, long, about 0.135-0.145 $\mathrm{mm}$, with 0-2 hairs on the basal half and the 3 subapical pairs all at about the same distance from the tip of the rostrum. Very similar, but rather poor, material was seen from Quercus alba and $Q$. macrocarpa from Illinois, Washington, D.C., Maryland, and New Jersey, but I am not sure that it belongs to the same species. Antennal segment II is almost always exactly 3 times as long as the width of its mid-portion. It must have been this Stegophylla to which Davis (1911) referred as material received from Monell that came from Washington, D.C.

Seemingly, the California material of Stegophylla has a name, for Swain (1919) referred to it as Phyllaphis quercicola Baker, quoting Baker (1916), but not quite correctly. Gillette and Palmer (1931) and Palmer (1952) even used the name Stegophylla quercicola (Baker) specifically for California material, for they gave Quercus agrifolia and $Q$. wislizenii as the only hosts. These authors overlooked the fact that Baker (1916) gave the new name more specifically to the species described by Davis (1911), and made a reserve for the material referred to by Davidson (1910). It appears that the California Stegophylla is indeed different from all the others. I name it Stegophylla essigi n. sp.

The American Stegophylla species that I can distinguish are dealt with in the accompanying key.

\section{Key to the Apterae of American Species of Stegophylla}

1(2). Second tarsal joints often ventrally with a hair about midway on the joint. Last rostral segment acutely triangular, very evenly tapering from near the base to almost the very apex, with 1 pair of the 3 subapical pairs of hairs 1.50 times as far from the apex as the others. The wax-plates on tergite VII consist of pore groups of very transparent rings, or fragments of rings, surrounding a small darker center and placed on a similarly dark field. On Quercus phellos, Raleigh, North Carolina, and probably other oaks; Missouri (?). (?) S. quercicola (Monell) ${ }^{10}$

\footnotetext{
${ }^{10}$ Material received from Dr. F. W. Quednau shows that this is his Stegophylla quercina n. sp., described in Canadian Ent. 98:417-19 (1966).
} 
2(1). Second tarsal joints ventrally with only a subapical pair of hairs. Last rostral segment rather blunt; at the dark apical part rounded, or suddenly very much more tapering. The wax-plates on tergite VII sometimes with extremely small ring-shaped structures, but then always also with round, very much larger, quite evenly stippled pore groups that may be bordered by a dark ring.

$3(4)$. Last rostral segment long, about $0.135-0.145 \mathrm{~mm}$, nine-tenths or more of last antennal segment, and considerably longer than second joint of hind tarsi. Antennal segment II about 3 times as long as the width of the mid-portion of the segment. On Quercus sinuata, Q. gambelli, Q. gunnisoni and, if the eastern Stegophylla is the same, Q. alba, Q. stellata, and Q. macrocarpa. Colorado, Utah; probably also Illinois, New Jersey, Washington, D.C., Maryland, etc.

S. quercifoliae (Gillette)

4(3). Last rostral segment considerably shorter, not over $0.125 \mathrm{~mm}$ long, much shorter than last antennal segment. Antennal segment II at most 2.50 times as long as the width of the mid-portion of the segment.

$5(6)$. Rostrum, when extended, not reaching the middle coxae (in specimens that are not shrunk), the last segment only $0.070-0.075 \mathrm{~mm}$ long, 1.00 1.10 times as long as segment II of antennae and only about .75-.80 of second joint of hind tarsi. On Quercus spp., Wisconsin and Illinois (Fitch, Davis).

S. querci (Fitch)

6(5). Rostrum, when extended, reaching well past the middle coxae, the last segment about $0.090-0.100 \mathrm{~mm}$ long, about 1.40-1.60 times as long as segment II of antennae and as long as second joint of hind tarsi. On Quercus agrifolia and other native species. California. S.essigin. sp.

Several characters of the genus Stegophylla Oestlund have not been mentioned in print, and are added here. All viviparae apterous; oviparae apterous; males within the species apterous or alate. In apterae, eyes small, with triommatidion (ocular tubercle), and on upper half with a more or less distinct horizontal area without facets, so that there is an upper and a lower eye. Antennae variably of 5 or 6 segments, with segment II longer, often very much longer than $I$ and often subequal to III. Secondary rhinaria (in males) nude, the primary ones hardly fringed. Trochanter in females not separated, in males partly separated. Tibiae not spinulose. Tarsi hardly spinulose; first tarsal joints always with 2 hairs; empodial hairs seemingly setaceous, actually very narrowly linear, blunt. Wax-plates in viviparae not bordered, but with more or less bor- dered groups of pores; oviparae with sharply bordered subsiphuncular waxplates with facets. Siphunculi present as elevated pores, with 5-8 hairs around them. Cauda hardly visible, with hairs that are very much shorter than other dorsal hairs.

Among American aphids, the genus Stegophylla stands isolated, but some available Japanese oak aphids are very nearly related. Diphyllaphis Takahashi, 1960, with $D$. konarae (Shinji) and $D$. alba Takahashi, and Nymphaphis Takahashi, 1960, with $N$. quercus Takahashi, differ from Stegophylla by having the minute siphunculi not surrounded by hairs; in apterae, they usually differ by having the upper half of a suture between trochanter and femur, and frequently by having a very short third hair on the first tarsal joints. Nymphaphis and Diphyllaphis differ only in that some of the empodial hairs in 
TABLE 28

SAMPLE MEASUREMENTS OF STEGOPHYLLA ESSIGI n. sp. (Fundatrices)

\begin{tabular}{|c|c|c|c|c|c|c|c|}
\hline \multirow{2}{*}{$\begin{array}{l}\text { Specimen } \\
\text { number }\end{array}$} & \multirow{2}{*}{$\begin{array}{l}\text { Body } \\
\text { length }\end{array}$} & \multirow{2}{*}{ Antennae } & \multicolumn{3}{|c|}{ Antennal segments } & \multirow{2}{*}{$\begin{array}{l}\text { Diameter } \\
\text { of the } \\
\text { siphunculi }\end{array}$} & \multirow{2}{*}{ Cauda } \\
\hline & & & III & IV & $\mathbf{V}$ & & \\
\hline 1. & 1.52 & 0.49 & 0.14 & 0.10 & 0.14 & 0.03 & 0.02 \\
\hline $3 \ldots$ & 1.54 & 0.43 & 0.09 & 0.08 & 0.13 & 0.03 & 0.02 \\
\hline $4 \ldots \ldots \ldots$ & 1.45 & 0.46 & 0.12 & 0.09 & 0.14 & 0.03 & 0.02 \\
\hline
\end{tabular}

Diphyllaphis have a faintly spathulate tip, which is not enough for a generic differentiation. Therefore, Nymphaphis Takahashi, 1960, type species $N$. quercus Takahashi, 1960, can be suppressed as a synonym of Diphyllaphis Takahashi, 1960, type species Phloeomyzus konarae Shinji, 1924. Diphyllaphis has all the other curious traits as to eyes, antennae, legs, cauda, etc., of Stegophylla. Sexuals of the Japanese species are not yet known.

Stegophylla mordvilkoi Aizenberg was described from southern Russia, and it also has been recorded from Italy and Turkey. I could not study type material, but Dr. G. Remaudière, Paris, France, who found the species in Turkey, most kindly gave me some males and oviparae. The description by Aizen- berg (1932) mentioned the absence of hairs around the siphunculi, which suggested that the species does not belong in Stegophylla Oestlund. Examination of the Turkish material confirmed that S. mordvilkoi Aizenberg, 1932, should be transferred to Diphyllaphis Takahashi.

There are no reliable printed references to alate females in this genus, and it is possible that they never develop, a condition that is also known in a few adelgine aphid genera. In Stegophylla, the means of distribution and the chances of speciation through isolation would then be comparable to those in nonparthenogenetic coccids, in which only alate males can provide the essential long-distance transport of genes.

\section{Fundatrix}

In life. Dark green; covered with curly white wool.

In mounted specimens. Very much like apterae of later generations, but antennae nearly always of 5 segments and comparatively just longer. (See table 28. )

Collection data. Specimens nos. 1-4 from galls on Quercus agrifolia, Berkeley, Alameda County, California, April 9, 1964, leg. H.R.L., no. 217.

\section{Apterous viviparous female}

In life. Light grayish green to pale olive; covered with woolly wax.

\section{essigi n. sp.}

In mounted specimens. Broadly oval, about $1.25-1.75 \mathrm{~mm}$ long, membranous, with dusky head; down the dorsum run 6 rows of dusky sclerites, each bearing 1 hair, a variable number (3-14) of roundish, evenly stippled wax-glands about $0.006-0.013 \mathrm{~mm}$ in diameter, and some ill-defined, very small groups of stipples; these sclerites are often absent or rudimentary on anterior tergites, caudad larger, on tergite VII fused to 4 sclerites, on VIII fused to an uninterrupted band. Dorsal hairs thin and rather long, on tergite III about 0.026 $\mathrm{mm}$, on tergite VIII about $0.048 \mathrm{~mm}$. Antennae of 5 or 6 segments, the num- 
TABLE 29

SAMPLE MEASUREMENTS OF STEGOPHYLLA ESSIGI n. sp. (Apterous Viviparous Females)

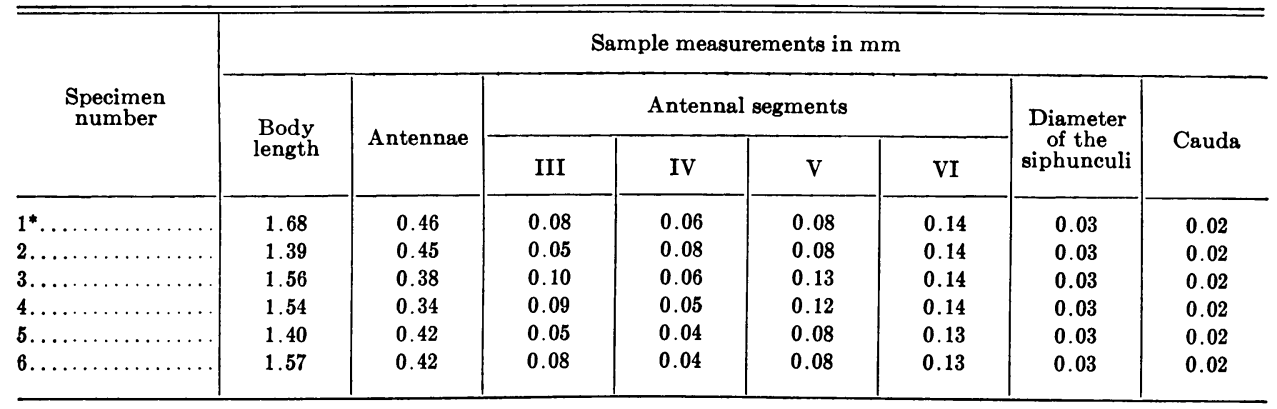

* Specimen no. 1 is the holotype.

ber correlated with size of body; segment II 1.75-2.40 times as long as the width of the mid-portion of the segment, with 3-4 hairs; segments of flagellum with transverse lines of obscure nodules. Eyes small, with an upper group of 4 or 5 ommatidia and a lower group of 13-18 lenses. Vertex with glands like those on dorsal sclerites. Rostrum, when extended, reaching past middle coxae; apical segment with rather straight, apically rounded sides, mostly without, sometimes with 1 , very rarely 2 , hairs on basal half, 0.09-0.10 $\mathrm{mm}$ long, almost independently of size of body. Legs pallid, with very thick femora (hind femora about 3.00-3.25 times as long as their maximum width) and stout tibiae; no trace of a trochanter; tibiae with few hairs with very fine apices; dorsal hairs on mid-portion of hind tibiae about as long as the local diameter of the joints; apex of hind tibiae with 4 hairlike spines; first tarsal joints with 2 long hairs. Siphunculi poriform, about $0.030 \mathrm{~mm}$ wide, in the center of a convex sclerite of about 0.11 mm diameter with 5-7 hairs; this sclerite caudad fused with a gland-bearing marginal sclerite. Cauda not defined, a transverse sclerite about 5 times as wide as long, with 2 , sometimes 3 , very short hairs about $0.010-0.012 \mathrm{~mm}$ long. Subgenital plate with 6-10 hairs on anterior half. Rudimentary gonapophyses, 2. (See table 29.)
Collection data. Specimens nos. 1-3 from Quercus agrifolia, Berkeley, Alameda County, California, November 9, 1963, leg. H.R.L., no. 66; specimen no. 4 from $Q$. agrifolia, Los Gatos, Santa Clara County, California, December 22, 1963, leg. H.R.L., no. 107; specimens nos. 5 and 6 from $Q$. lobata, 5 miles east of Visalia, Tulare County, California, November 5, 1963, leg. R. van den Bosch (H.R.L., no. 67).

\section{Oviparous female}

In life. Dirty, obscure green, with paler center, rarely pink, not woolly dorsally, with conspicuous subsiphuncular wax-beards.

In mounted specimens. Very much like viviparous females, but the dorsal sclerites much smaller and the dorsal wax-glands much reduced in number. Below the siphunculi is an extremely large, dark, sclerotic wax-gland, in length equal to hind tibiae, with a narrow, parallel-sided incision on the anterior border and two round perforations more caudad; its surface reticulated and stippled. Antennae distinctly longer than in apterae viviparae, of 6 segments. Hind tibiae darkened, very strongly swollen, thicker than the hind femora, about 3 times as thick as the other tibiae, with some 50 angular to oval pseudosensoria. Cauda mostly with 4 hairs. Subgenital plate with very 
TABLE 30

SAMPLE MEASUREMENTS OF STEGOPHYLLA ESSIGI n. sp. (Oviparous Females)

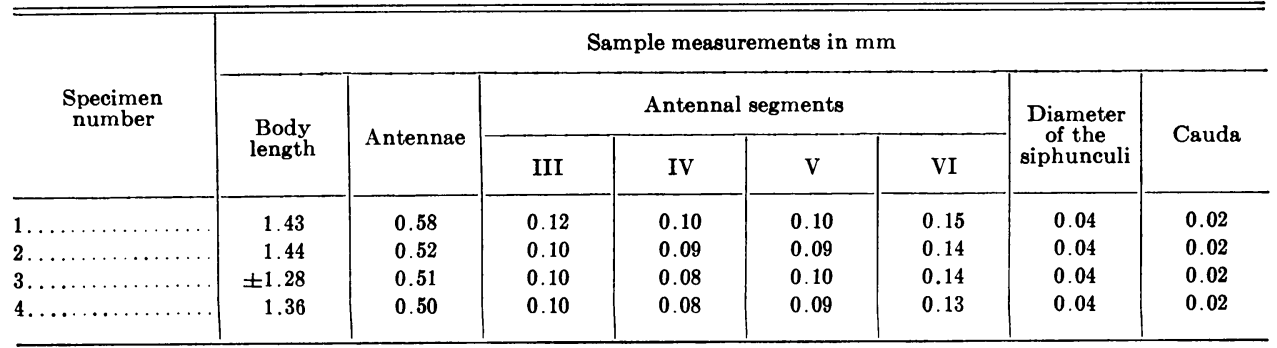

much more numerous hairs all over its surface. Rudimentary gonapophyses, 4 small, dark tubercles. (See table 30.)

Collection data. Specimen no. 1 from same colony as apterous viviparae nos. $1-3$, but November 17, 1963, leg. H.R.L., no. 89 ; specimens nos. $2-4$ with apterous viviparae nos. 5 and 6 .

\section{Alate male}

In life. With blackish head and thorax, antennae, and legs, and blackish green abdomen; wax-wool is lacking.

In mounted specimens. Head and thorax black, abdomen colorless and membranous, with only stigmal plates, siphuncular sclerites, more or less vague bands on tergite VII and VIII, and the dark genitalia pigmented. Only isolated wax-pores, no glands, visible on the siphuncular sclerites and on sclerites VII and VIII. Antennal segment II about 1.50 times as long as its maximum width; segment III, mainly near apex, with 3-7 small, clustered rhinaria; IV with $3-5$, V with 3-6, and VI with 1-6 secondary rhinaria. Eyes large, normally faceted, but without triommatidion. Rostrum, notwithstanding small size of body, with same length of apical segment. Wings with unusual veins; the latter not marked by lines or scales, but just vague, brown bands that are darker in the middle than at the indistinct borders; media once-forked; hind wings with 1-2 obliques. Legs dark, with the tibiae apicad and the tarsi paler than the femora, rather slender; trochanter indicated by a usually almost complete encircling suture or line. Siphunculi with a porus only $0.010 \mathrm{~mm}$ wide, eccentrically placed on a sclerite with a largest measure of $0.050 \mathrm{~mm}$. Cauda only about 3 times as wide as long, with 2 hairs. Genitalia very dark and conspicuous, with broad, flat, blunt claspers. (See table 31, in which data are given from a single specimen.)

TABLE 31

SAMPLE MEASUREMENTS OF STEGOPHYLLA ESSIGI n. sp.

(Alate Male-Single Specimen)

\section{MEASUREMENTS IN MM \\ Body length: 1.00 . \\ Antennae: 0.60. \\ Antennal segments: III, $0.11 ; \mathrm{IV}, 0.11 ; \mathrm{V}, 0.13$; VI, 0.16 . \\ Siphunculi: 0.01 . \\ Cauda: 0.01 .}

Number of rhinaria on antennal segments: III, 4 and 7 ; IV, 5 and $3 ; \mathrm{V}, 5$ and $6 ; \mathrm{VI}, 1$ and 1 .

Collection data. Specimen was taken with oviparae nos. 2-4.

Notes. This aphid infests a number of California species of oaks. It has been found on Quercus agrifolia, $Q$. dumosa, Q. douglasii, Q. garryana, $Q$. kelloggii, $Q$. lobata, and $Q$. wislizenii.

The species is not rare, but in an area where it occurs, often only a very few trees out of many have colonies. It overwinters as eggs, but probably occasionally also as viviparae, on evergreen oaks, for colonies maintained themselves between leaves spun together by cater- 
pillars until early February on Quercus agrifolia near Berkeley, California.

Fundatrices feed as larvae near the edges on the upper sides of young leaves, which edges turn upward and fold over the insect. These folded marginal pseudogalls develop thickened, stiff walls, and usually turn red. In Berkeley, fundatrices were mature on April 1, and began producing young a few days later. In late autumn, I found colonies only on the undersides of leaves, more or less exposed, and only on evergreen oaks, with very few oviparae. Colonies collected by Dr. R. van den Bosch near Visalia, California, on the deciduous Quercus lobata consisted of about 90 per cent oviparae, with a few males and very few viviparous females. The males are alate, or apterous with a distinct pterothorax. In some populations, most or all males seem to be wingless, in other populations winged, independently of host species or locality.

\section{Utamphorophora bumboldti (Essig, 1941)}

Myzus humboldti Essig was originally described from Viburnum, but since all later finds are from Physocarpus, Dr. Essig, according to a note in his collection, already suspected that the aphids did not live on Viburnum. I also found it on Physocarpus near Berkeley, Alameda County, California.

The life cycle of $U$. humboldti has not been investigated, but from my own observations it appears that grasses are the secondary host plants. Rather large colonies were found on the undersides of leaves of Polypogon monspeliensis, growing in mud close to the edge of a pond near Berkeley, and single specimens or small colonies on unidentified grasses growing on the north sides of the bases of trees in the streets of Berkeley.

The very characteristic color of the species has not been described. Adult apterae are apple green, with a faint, paler green median line, not shiny, not powdery. Siphunculi pale, darker
Swain (1919) recorded colonies from both the upper and undersides of leaves in summer; this has also been recorded for other Stegophylla species.

Differences from other species are indicated in the key accompanying the preceding section, pages 614 and 615 .

Type material. Holotype: Apterous viviparous female (specimen no. 1 of measurements) from Quercus agrifolia, Berkeley, Alameda County, California, November 9, 1963, leg. H.R.L., no. 66. Paratypes: Apterae with data as for holotype; others with the same data, but November 17, 1963, leg. H.R.L., no. 89; apterae from Quercus agrifolia, Los Gatos, Santa Clara County, California, December 22, 1963, leg. H.R.L., no. 107; apterae and sexuals from Quercus lobata, near Visalia, Tulare County, California, November 5, 1963, leg. R. van den Bosch (H.R.L., no. 67) ; fundatrices from Quercus agrifolia, Berkeley, Alameda County, California, April 9, 1964, leg. H.R.L., no. 217.

apicad. Cauda lighter green than body. Nymphs of all instars with two longitudinal pleural stripes of bright green on a light green dorsum, looking like larvae of Cavariella spp. Alatae with blackish brown head and thorax; marginal sclerites on abdomen olive brown; two marked, broad, pleural longitudinal stripes on abdomen, composed of olive dots surrounded by bright green; the middle, spindle-shaped area of abdominal dorsum pale yellowish green. Antennae dark; siphunculi dusky, with mottled swollen area.

Myzus physocarpi Pepper, 1950, described from a Physocarpus species in Pennsylvania, after comparison of paratypes appears to be a synonym of Myzus humboldti Essig. Sitomyzus columbiae Richards, 1960, described from grasses in British Columbia, agrees in all details of his description with exules of $M$. humboldti Essig, and may be a synonym as well. No material for comparison is available. 
The mysterious Amphorophora howardii Wilson, 1911, cannot be placed in Utamphorophora. It has been considered to belong to the life cycle of
Glabromyzus rhois (Monell, 1879), but this is not likely.

(See page 586; also, refer to Riley and Monell, 1879.)

\section{ACKNOWLEDGMENTS}

I wish to express my heartfelt thanks to several friends, on three campuses of the University of California, for their helpfulness.

The following fellow entomologists either accompanied and guided me on collecting trips in several areas of California, or submitted pertinent material for study: Drs. William W. Allen, Julius H. Freitag, Abraham E. Michelbacher, Thomas E. Mittler, and Robert van den Bosch (Berkeley); Robert C. Dickson and Evert I. Schlinger (Riverside); and William $\mathrm{H}$. Lange (Davis).

Dr. Helen K. Sharsmith, of the Department of Botany (Berkeley), iden- tified several nonflowering pieces of plants that were infested with aphids.

Dr. Edward S. Sylvester, of the Department of Entomology and Parasitology (Berkeley), went with me on various collecting trips, and later rendered invaluable assistance in producing this paper by making many linguistic and stylistic improvements.

Grant V. Wallace, of Agricultural Publications (Berkeley), made a thorough editorial analysis of the manuscript while preparing it for the printer, added the abstract and the classified index, and altered the tables to conform with Hilgardia's style.

\section{LITERATURE CITED}

Aizenbera, E. E.

1932. A new species of Aphididae of Caucasus (Stegophylla mordvilkoi sp. n.). Bul. Stat. Biol. Bolchevo, livr. 5-8:75-80.

BAKer, A. C.

1916. The identity of Eriosoma querci Fitch (Aphididae, Hom.). Ent. News (Philadelphia) 27:359-66.

BARTHOLOMEW, P. S.

1932. Six new species of aphids, with records of other species new to California. Ann. Ent. Soc. Amer. $25: 713-27$.

BÖRNER, C.

1930. Beiträge zu einem neuen System der Blattläuse. Arch. f. Klassif. Phylog. Ent. 1:115-94.

1950. Neue europäische Blattlausarten. Edited by Börner. 19 pp.

1952. Europae Centralis Aphides. Mitteil. Thüring. Bot. Ges. Beiheft 3:1-488.

Börner, C., and F. A. SchILdER

1932. Aphidoidea. In: Sorauers Handb. d. Pflanzenkrankheiten, ed. IV, 5, part 2:551-715.

Brierley, P., and F. F. SMiTh

1957. Carnation viruses in the United States. Phytopathology 47:714-21.

Cowen, J. H.

1895. Aphididae. In: Gillette and Baker, Hemiptera of Colorado. Bul. Agr. Expt. Sta. Colorado, Tech. Ser. 1:115-25.

Davidson, W. M.

1910. Further notes on the Aphididae collected in the vicinity of Stanford University. Jour. Econ. Ent. 3:372-81.

Davis, J. J.

1911. The woolly aphis of oak (Phyllaphis? querci Fitch) (Hemipt.). Ent. News (Philadelphia) 22:241-44.

1912. Williams' "The Aphididae of Nebraska": a critical review. Univ. Stud., Lincoln, Nebraska 11:253-90.

EASTOP, V. F.

1951. A list of aphids collected in Berkshire. Entomologist 84:107-12. 
Essig, E. O.

1941. A new species of Myzus from Humboldt County, California (Homoptera, Aphididae). Pan-Pac. Ent. 17:182-84.

Fitch, A.

1859. Fifth report on the noxious, beneficial, and other insects of the state of New York. New York Agr. Soc. Trans. 18:781-854.

FlUTter, H. J. DE

1933. Bijdrage tot de kennis der oecologie en morphologie van Eriosoma lanuginosum (Hartig), de "bloedluis" onzer pereboomen. Tijdschr. Plantenziekten 39:45-72.

Gillette, C. P.

1914. Two Colorado plant lice (Hemip.-Homop.). Ent. News (Philadelphia) 25:269-75.

GiLlette, C. P., and M. A. PALMER

1931. The Aphididae of Colorado, part 1. Ann. Ent. Soc. Amer. 24:827-934.

HiLle Ris Lambers, D.

1946. Aphids. In: H. Alta and W. M. Docters van Leeuwen, Gallenboek. Amsterdam. 288 pp.

1953. Contributions to a monograph of the Aphididae of Europe. V. Temminckia 9:1-176.

1960. The genus Chaitophorus Koch in North America (Homoptera, Aphididae). Tijdschr. v. Ent. 103:1-30.

HotTes, F. C.

1934. Aphid descriptions and notes. Proc. Biol. Soc. Washington 47:1-8.

HotTEs, F. C., and T. H. Frison

1931. The plant lice, or Aphiidae [sic], of Illinois. Bul. Illinois Nat. Hist. Survey 19:121-447.

KNowlton, G. F., and M. W. AlleN

1937. Bramble fruit aphids. Ann. Ent. Soc. Amer. 30:309-15.

MacGillivray, M. E.

1954. Note on Myzus certus (Walker), an aphid new to North America (Homoptera: Aphidae). Canadian Ent. 86:190.

1958. A study of the genus Masonaphis Hille Ris Lambers, 1939 (Homoptera, Aphididae). Temminckia 10:1-131.

MASON, P. W.

1940. A revision of the North American aphids of the genus Myzus. U. S. Dept. Agr. Mise. Publ. 371:1-29.

MoRdVILKo, A.

1935. Die Blattläuse mit unvollständigem Generationszyklus und ihre Entstehung. Ergeb. u. Fortschritte Zool. 8:36-328.

Munz, P. A.

1963. A California flora. Univ. California Press, Berkeley and Los Angeles. $1681 \mathrm{pp}$.

OKAMOTO, H., and R. TAKAHASHI

1927. Some Aphididae from Corea. Insecta Matsumurana 1:131-48.

PALMER, M. A.

1952. Aphids of the Rocky Mountain region. Thomas Say Foundation 5:1-452.

RICHARDS, W. R.

1960. A new species and new subgenus of Sitomyzus Hille Ris Lambers (Homoptera: Aphididae). Canadian Ent. 92:770-75.

RILEY, C. V., and J. MONELI

1879. Notes on the Aphididae of the United States, with descriptions of species occurring west of the Mississippi. U. S. Geol. Geog. Surv. Bul. 5:1-32.

Stroyan, H. L. G.

1963. A new genus and species of Eriosomatinae (Homoptera: Aphidoidea). Proc. Roy. Ent. Soc. London (ser. B) 32:81-85.

SwAIN, A. F.

1919. A synopsis of the Aphididae of California. Univ. California Publ. Ent. 3:1-221.

TARAHASHI, $R$.

1924. Aphididae of Formosa. III. Formosa Dept. Agr. Res. Inst. Rept. 10:1-121.

1959. Some aphids related to Nipponaphis Pergande in Japan (Homoptera). Bul. Univ. Osaka Prefecture (ser. B) 9:1-8.

Williams, T. A.

1911. The Aphididae of Nebraska. Univ. Stud., Lincoln, Nebraska 10:85-175.

WILSON, H. F.

1911. Two new genera and seven new species of the family Aphididae. Canadian Ent. 43:59-65. 


\section{CLASSIFIED INDEX TO APHID GENERA AND SPECIES}

\section{New Genera}

Paracolopha; type-species, Dryopeia morrisoni Baker, 1919, 600

Pentamyzus; type-species, Pentamyzus graminis n. sp., 601

\section{New Species and Subspecies}

Amphorophora stachyophila, from Stachys rigida, $\mathbf{5 7 0}$

Braggia deserticola, from Eriogonum fasciculatum, 574

Braggia deserticola subsp. thanatophila, from Eriogonum sp., $\mathbf{5 7 6}$

Braggia eriogoni subsp. atra, from Eriogonum sp., 577

Braggia eriogoni subsp. californica, from Eriogonum spp., 577

Braggia urovaneta subsp. pachysiphon, from Eriogonum latifolium, 578

Chaitophorus eoessigi, from Salix sp., 578

Corylobium vandenboschi, from Corylus cornuta var. californica, 531

Glabromyzus schlingeri, from Rhus diversiloba $(\&), 584$

Macrosiphoniella cinerescens, from Achillea californica, 587

Macrosiphum raysmithi, from Lonicera involucrata var. ledebouri, 589

Masonaphis macgillivrayae, from Raphiolepis indica, 591

Masonaphis richardsi subsp. pacifica, from Anaphalis margaritacea, 593

Myzus (Nectarosiphon) dianthicola, from Dianthus caryophyllus, 596

Pentamyzus graminis, from grasses, 601

Pleotrichophorus obscuratus, from Artemisia californica, 605

Sitobion sylvesteri, from Elymus mollis and Ammophila arenaria, 611

Stegophylla essigi, from Quercus agrifolia, $Q$. dumosa, $Q$. douglasii, Q. garryana, $Q$. kelloggii, Q. lobata, and Q. wislizenii, 616

\section{New Combinations (Transfers)}

Atarsaphis agrifoliae (Ferris), from Hamamelistes, 572

Braggia eriogoni (Cowen), from Aphis, 572, 576

Braggia eriogoni subsp. agathona (Hottes), from Aphis, 572, 576

Braggia urovaneta (Hottes), from Aphis, 572 , 578

Dactynotus erigeronensis subsp. baccharidis (Clarke), from Nectarophora, 583

Diphyllaphis mordvilkoi (Aizenberg), from Stegophylla, 616

Diphyllaphis quercus (Takahashi), from Nymphaphis, 615, 616
Glabromyzus howardii (Wilson), from Amphorophora (provisional), 586, 587

Macrosiphoniella pennsylvanica (Pepper), from Macrosiphum, $\mathbf{5 8 8}$

Masonaphis ceanothi (Bartholomew), from Amphorophora, 591

Ovatus phloxae (Sampson), from Phorodon, 600

Paracolopha morrisoni (Baker), from Dryopeia, 600, 601

Rhopalosiphoninus (Myzosiphon) solani (Thomas), from Megoura, 610

Sitobion rhamni (Clarke), from Myzus and Macrosiphum, 611

Stegophylla querci (Fitch), from Eriosoma and Phyllaphis, 613, 614

Utamphorophora humboldti (Essig), from Myzus, 619

\section{New Synonyms Suggested}

Eriosoma inopinatum Alfieri, of Eriosoma pyricola Baker and Davidson, 584

Myzus physocarpi Pepper, of Utamphorophora humboldti (Essig), 619

Myzus plantagineus of Williams, Davis, and Mason (nec Passerini), of Ovatus phloxae (Sampson), 600

Rhopalosiphoninus persimilis Hille Ris Lambers, of Rhopalosiphoninus

(Myzosiphon) solani (Thomas), 610

Stegophylla quercina Quednau, of Stegophylla quercicola (Monell), 614

\section{New Notes on Life Cycles}

Pentamyzus graminis n. sp., 604

Rhopalomyzus grabhami (Cockerell), 609

Utamphorophora humboldti (Essig), 619

\section{Other Species Described or Noted}

Amphorophora howardii Wilson, 586, 620 Amphorophora rubitoxica Knowlton, 571

Aphis avicularis (Hille Ris Lambers), 572

Aphis lugentis Williams, 572

Braggia echinata Gillette and Palmer, 572

Braggia uncompahgrensis Hottes, 572

Chaitophorus populialbae (Fonscolombe), 581

Corylobium avellanae (Schrank), 582

Crypturaphis grassii Silvestri, 601

Dactynotus achilleae (Koch), 582

Dactynotus (Uromelan) bonitus (Hottes), 582

Dactynotus erigeronensis (Thomas), 582

Dactynotus russellae Hille Ris Lambers, 583, 592

Diphyllaphis alba Takahashi, 615

Diphyllaphis konarae (Shinji), 615

Drepanosiphum zimmermanni Börner, 583

Drepanosiphum platanoidis (Schrank), 583

Epameibaphis atricornis Gillette and Palmer, 583 
Eriosoma pyricola Baker and Davidson, 584 Euthoracaphis cinnamoniae (Shinji), 584 Euthoracaphis umbellulariae (Essig), 584 Fimbriaphis gentneri (Mason), 584

Gharesia polunini Stroyan, 584

Gobaishia ulmifusa (Walsh and Riley), 601 Macrosiphum coryli Davis, 581

Macrosiphum oredonense Remaudière, 590 Masonaphis ceanothi (Bartholomew), 591 Masonaphis corylinum (Davidson), 592 Masonaphis lambersi MacGillivray, 591 Masonaphis richardsi MacGillivray, 592 Masonaphis wahnaga (Hottes), 592 Myzocallis agrifolicola Richards, 594 Myzus (Nectarosiphon) ajugae Schouteden, 600

Myzus (Nectarosiphon) ascalonicus Doncaster, 599

Myzus (Nectarosiphon) certus (Walker), 598, 600

Myzus (Nectarosiphon) ligustri (Mosley), 598

Myzus (Nectarosiphon) myosotidis Börner, 599
Myzus (Nectarosiphon) persicae (Sulzer), $585,598,599$

Myzus (Nectarosiphon) polaris Hille Ris Lambers, 597, 598, 599

Nippocallis kuricola Matsumura, 596

Pleotrichophorus gnaphalodes (Palmer), 605

Pleotrichophorus patonkus (Hottes and

Frison), 604, 605

Pleotrichophorus pseudoglandulosus (Palmer), 605, 606

Rhopalomyzus grabhami (Cockerell), 607

Rhopalomyzus poae (Gillette), 607

Rhopalosiphoninus (Myzosiphon) staphyleae (Koch), 609, 610

Rhopalosiphoninus (Myzosiphon) tulipaellus (Theobald) 609, 610

Sitobion avenae (Fabricius), 611

Sitobion fragariae (Walker), 611

Sitobion rhamni (Clarke), 611

Stegophylla querci (Fitch), 614, 615

Stegophylla quercicola (Monell), 614

Stegophylla quercifoliae (Gillette), 614, 615

Utamphorophora humboldti (Essig), 619 

The journal HILGARDIA is published at irregular intervals, in volumes of about 650 to 700 pages. The number of issues per volume varies.

Single copies of any issue may be obtained free, as long as the supply lasts; please request by volume and issue number from:

\author{
Agricultural Publications \\ University Hall \\ University of California \\ Berkeley, California 94720
}

The limit to nonresidents of California is 10 separate titles. The limit to California residents is 20 separate titles.

The journal will be sent regularly to libraries, schools, or institutions in one of the following ways:

1. In exchange for similar published material on research.

2. As a gift to qualified repository libraries only.

3. On a subseription basis $-\$ 7.50$ a year paid in advance. All subscriptions will be started with the first number issued during a calendar year. Subseribers starting during any given year will be sent back numbers to the first of that year and will be billed for the ensuing year the following January. Make checks or money orders payable to The Regents of The University of California; send payment with order to Agricultural Publications at above address. 